Universidad de Lima

Facultad de Derecho

Carrera de Derecho

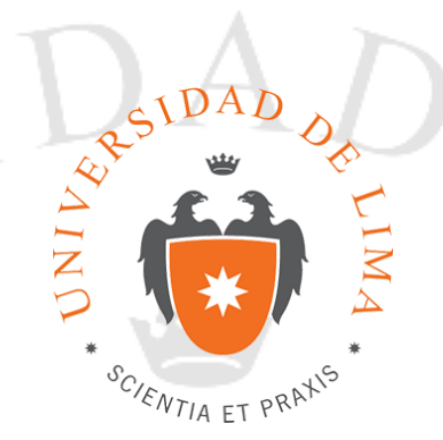

\title{
¿LAS PATENTES MATAN?
}

Tesis para optar por el título profesional de Abogado

Diego Aaron Garavito Martinez

20080416

\section{Asesor}

Enrique Alberto Ghersi Silva

Lima - Perú

Agosto del 2017 
Para mi madre, que me metió en esto y luego me ayudó a salir.

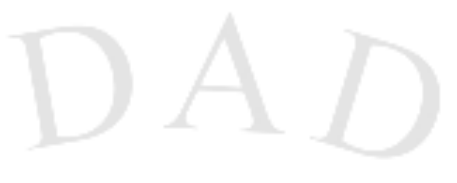

Si hay amor, las cicatrices de la viruela son bellas como hoyuelos.

Proverbio japonés

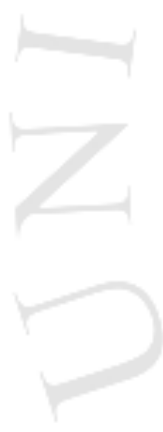




\section{¿LAS PATENTES MATAN? CONSIDERACIONES ACERCA DEL SISTEMA DE PATENTES Y LA LICENCIA OBLIGATORIA POR MOTIVOS DE SALUD PÚBLICA}

"El SIDA es un problema mayor, pero debilitar la propiedad intelectual no es la solución" Alan F. Holmer 


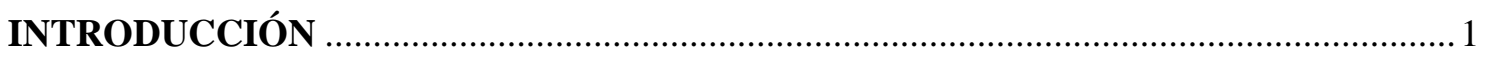

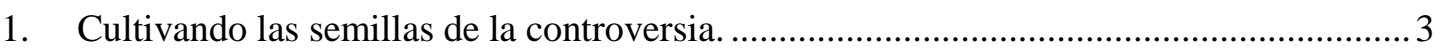

CAPÍTULO I: EVOLUCIÓN HISTÓRICA DEL SISTEMA DE PROPIEDAD

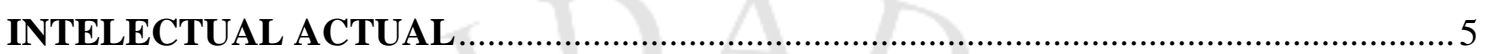

1.1. La propiedad intelectual a la luz de la OMC..........................................................

1.1.1. La posición de los países sobre la regulación de propiedad intelectual. ............... 9

1.1.2. Inclusión de los países en desarrollo en el acuerdo ADPIC................................. 11

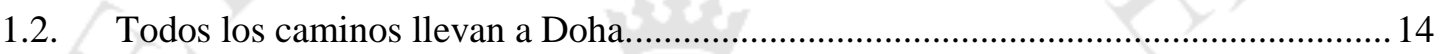

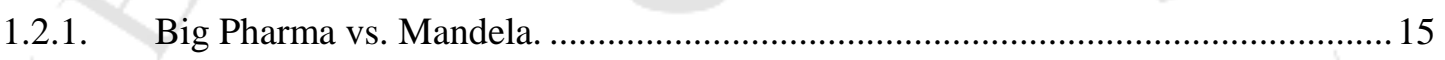

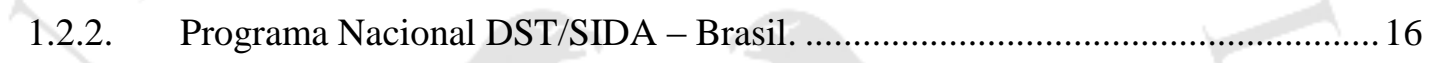

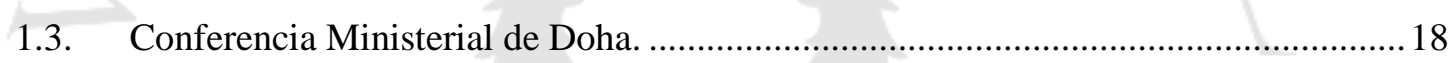

\section{CAPÍTULO II: VENTAJAS Y DESVENTAJAS DEL SISTEMA DE PATENTES DE}

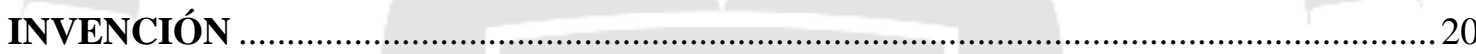

2.1. Abajo el sistema de patentes. Argumentos en contra del sistema de patentes............ 20

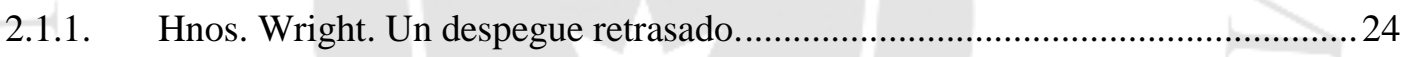

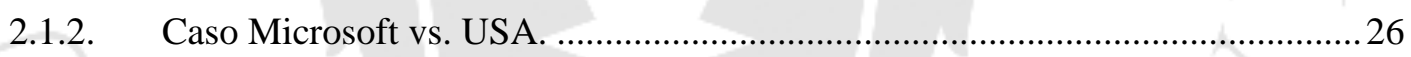

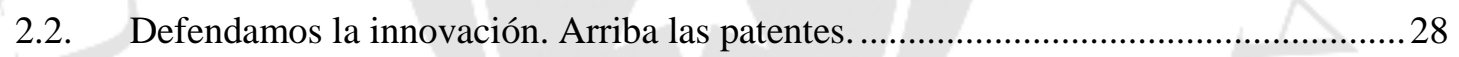

2.3. Sistemas alternativos a los derechos de propiedad intelectual..................................... 32

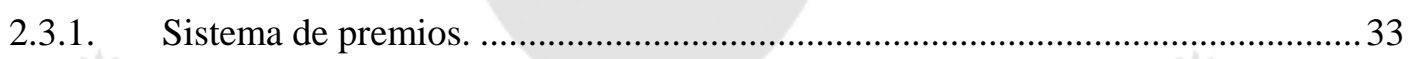

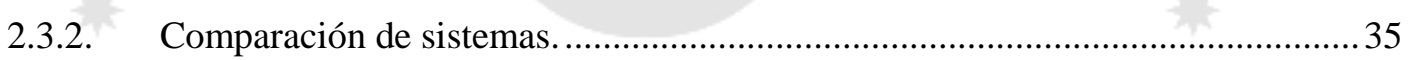

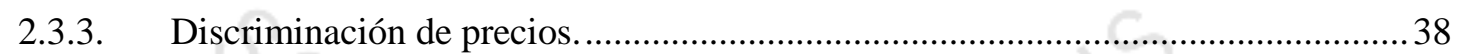

2.4. ¿Resulta necesario cambiar el modelo actual de innovación? ......................................43

CAPÍTULO III: EL EQUILIBRIO ES LA CLAVE. SALVAGUARDAS EN LOS ADPIC.

3.1. Sistema de Propiedad Intelectual: Marco legal. ...........................................................4 47

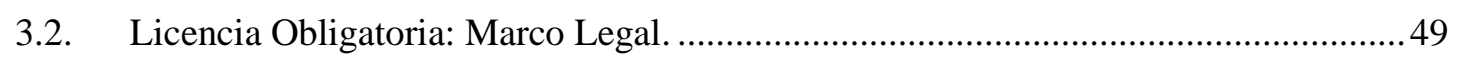

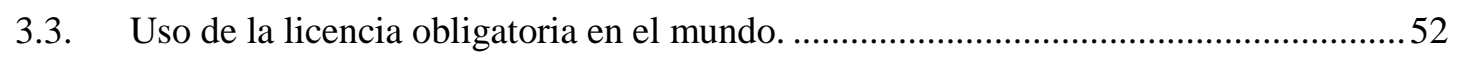

3.4. Consecuencias del abuso de las licencias obligatorias................................................5

CAPÍTULO IV: SISTEMA DE PATENTES EN EL SECTOR FARMACÉUTICO......... 60

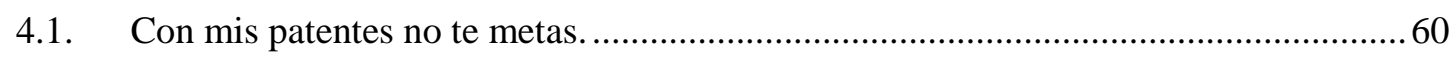

4.2. Críticas al sistema de patentes en el sector farmacéutico.............................................63 
4.2.1. Distorsión financiera.

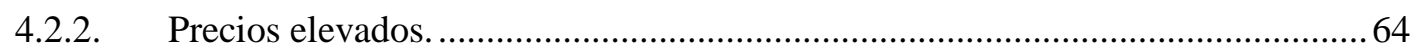

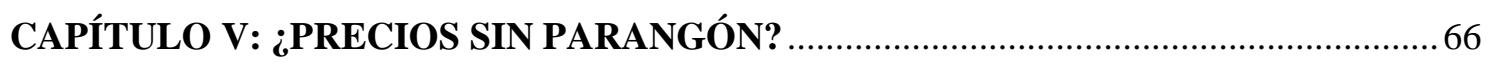

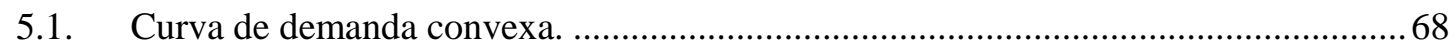

5.2. El problema de la curva de demanda convexa............................................................ 69

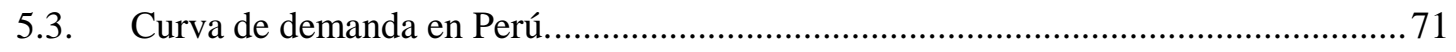

\section{CAPÍTULO VI: ASPECTOS A TOMAR EN CUENTA PARA LA EMISIÓN DE UNA}

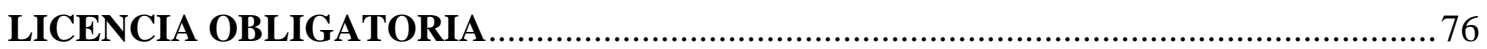

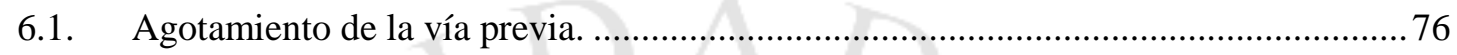

6.1.1. Compra y distribución de medicamentos................................................................. 78

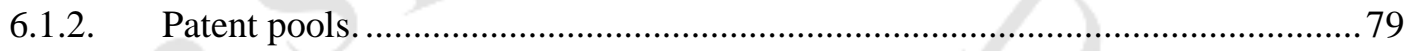

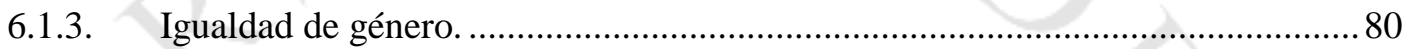

6.2. Situaciones de emergencia nacional o interés público............................................... 81

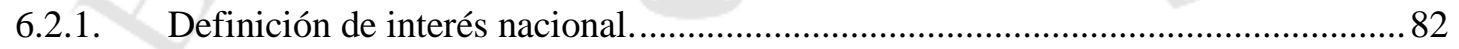

6.2.2. Definición de emergencia nacional.................................................................. 90

6.2.3. Procedimiento de declaratoria del "interés público" o "urgencia extrema"........92 92

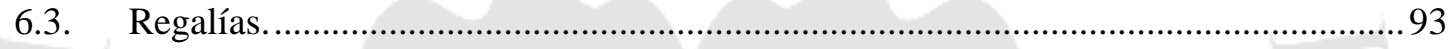

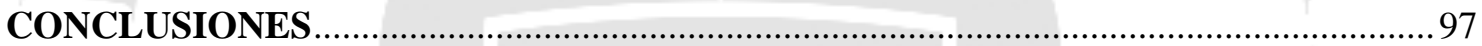

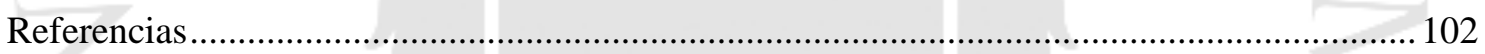




\section{ÍNDICE DE FIGURAS}

Figura 1. Ingreso promedio anual per cápita en Perú. Año 2015 .............................................. 40

Figura 2. Evolución del flujo de caja para la creación de un nuevo producto farmacéutico........61

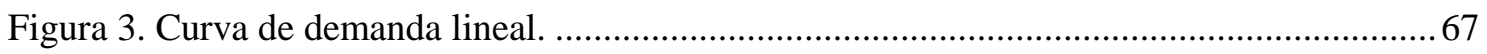

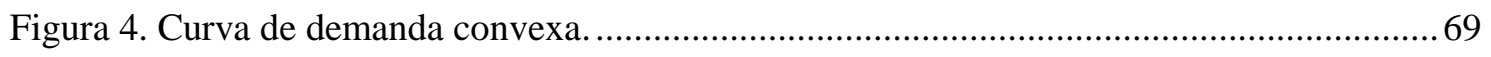

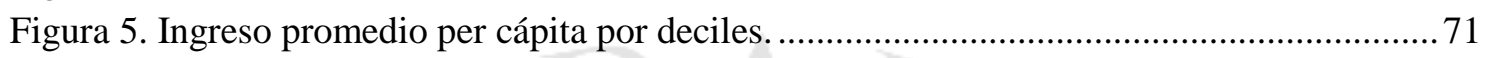

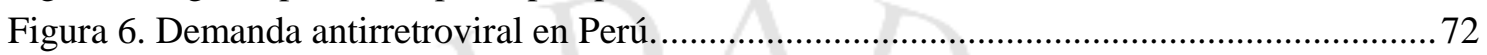

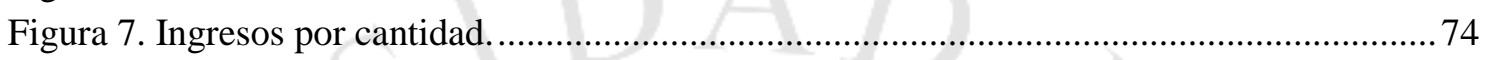

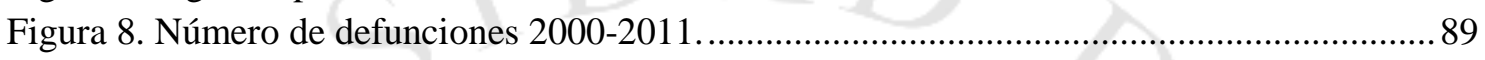




\section{ÍNDICE DE TABLAS}

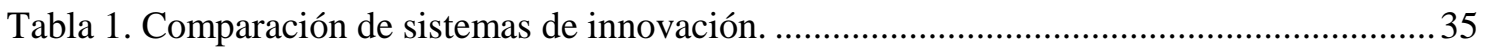

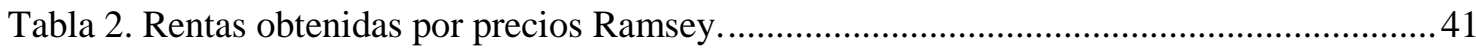

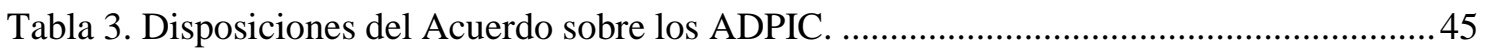

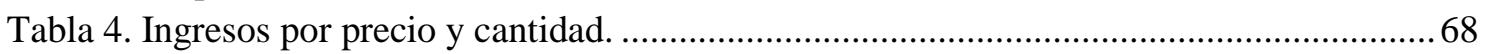

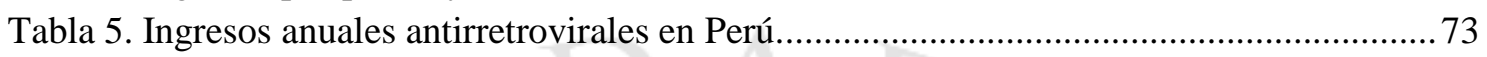

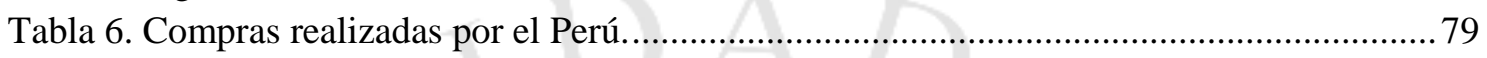

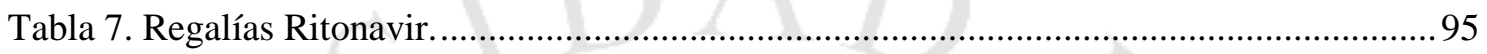




\section{ÍNDICE DE ANEXOS}

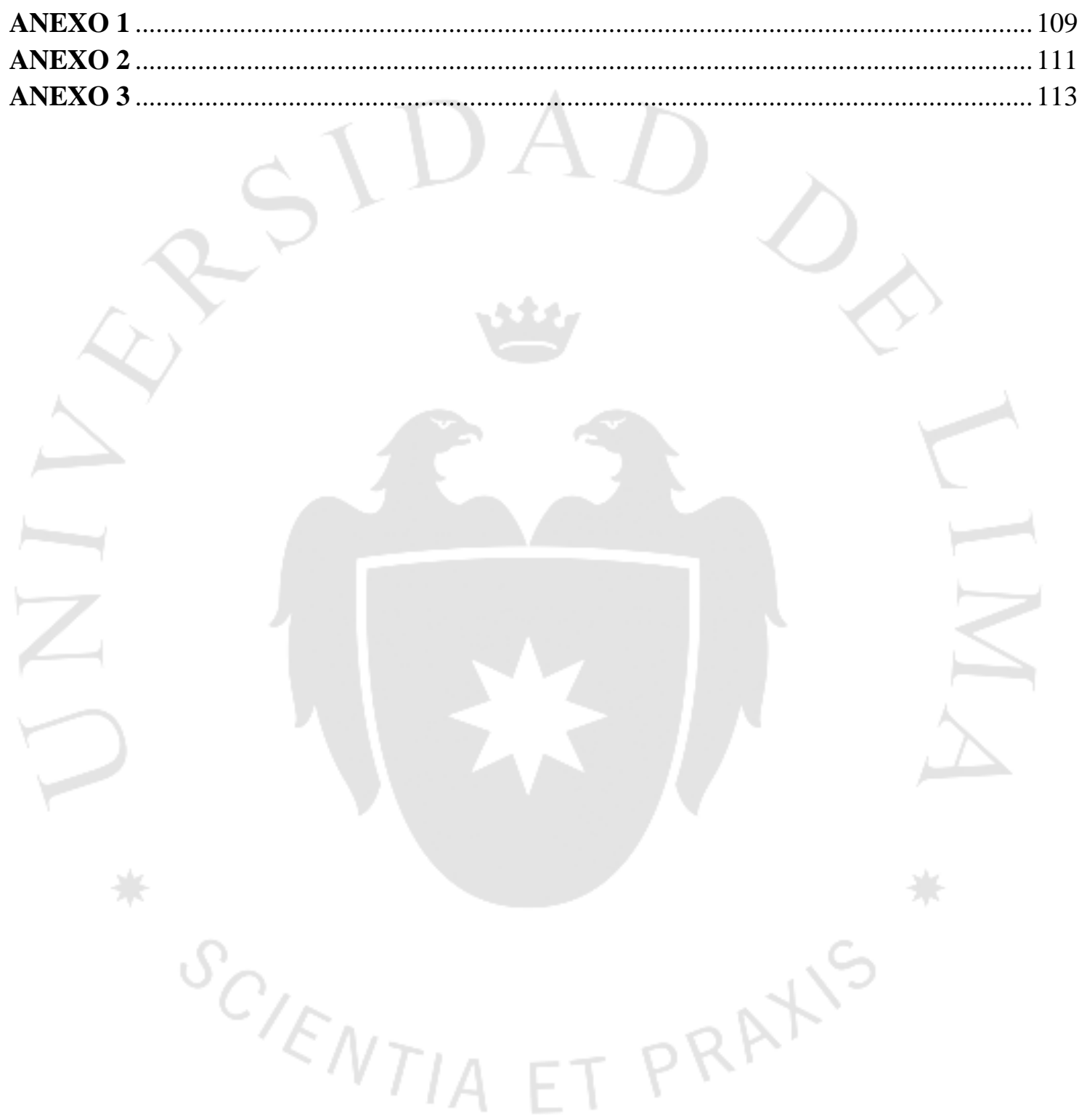




\section{INTRODUCCIÓN}

Hacia el final del 2013 un grupo de ONGs de lucha contra el VIH/SIDA enviaron una carta a la Ministra de Salud solicitando se declare de interés público el acceso al medicamento antirretroviral Atazanavir en aras de generar un ahorro para el Estado mediante la imposición de una licencia obligatoria. La crítica que ha despertado dicha iniciativa ha dado lugar a uno de los más importantes y constructivos debates en torno a la aplicación de licencias obligatorias en el Perú.

Esta iniciativa no ha sido el primer intento, ni será el último, en la búsqueda por obtener una licencia obligatoria de patente en nuestro país. La primera iniciativa de la que se tiene registro fue en octubre del 2003. En esa fecha el congresista aprista Daniel Robles López presentó una iniciativa legislativa, ${ }^{1}$ que propuso declarar de interés público el tratamiento del cáncer, el VIH/SIDA y la esquizofrenia con el objetivo de disminuir los costos del tratamiento de dichas enfermedades.

Las licencias obligatorias por motivos de salud pública han despertado el interés de los países para hacer frente a situaciones de emergencia de salud pública, con el objetivo de llevar medicamentos asequibles para aquellos que más los necesitan. Sin embargo, existe una tensión inevitable entre la necesidad de las empresas farmacéuticas para beneficiarse de sus invenciones patentadas y el deseo de proporcionar acceso a las personas sin capacidad económica para enfrentar tratamientos costosos.

El conflicto mencionado generó que el Comisionado Europeo para el Comercio, Peter Mandelson, en respuesta a la primera emisión de una licencia obligatoria en Tailandia advirtiera que "el uso de las licencias obligatorias no debe convertirse en una forma estándar de hacer negocios, ya que el recurso sistemático a las licencias obligatorias puede ser perjudicial para el sistema de patentes, así como con la innovación

\footnotetext{
${ }^{1}$ Proyecto de Ley 8542. Ver Anexo 2.
} 
y el desarrollo de nuevos medicamentos" (Mandelson, 2007) Mientras que al otro lado del océano, en Brasil, ${ }^{2}$ un folleto publicitario mostraba una conmovedora imagen de una madre sosteniendo en brazos a su pequeña hija con el mensaje "el uso de licencias obligatorias de fármacos utilizados en el cóctel contra el sida no es una declaración de guerra en contra de la industria farmacéutica. Realmente se trata de una lucha por la vida"3 (Brasil divulga programa de combate ã aids nos EUA, 2001).

La facultad de los países de utilizar las licencias obligatorias ha sido reconocida por el acuerdo de la Organización Mundial del Comercio sobre los Derechos de Propiedad Intelectual relacionados con el Comercio (ADPIC) ${ }^{4}$ para promover el acceso a los medicamentos. En el caso peruano, esta potestad también es reglamentada por el capítulo VII de la Decisión 486 de la Comunidad Andina. ${ }^{5}$

Desde una perspectiva empírica, se trata de valorar pérdidas y beneficios asociados a los dispositivos establecidos por la Ronda Uruguay. Resulta necesario encontrar un equilibrio entre lo bueno y lo malo que la propiedad intelectual otorga. Por un lado, estimula la eficiencia a través de la innovación y fomenta la rápida comercialización de las novedades y por el otro genera pérdidas de bienestar debido al monopolio de patentes.

\footnotetext{
${ }^{2}$ El gobierno brasileño determinó por primera vez en la historia del país y de Latinoamérica, la limitación del derecho de patente sobre el medicamento Efavirenz con el objetivo de reducir su costo en el mercado interno a través del Decreto $\mathrm{N}^{\mathrm{o}} 6.108$.

${ }^{3}$ Frase original: "La fabricación local de la mayoría de los fármacos utilizados en el cóctel contra el Sida no es una declaración de guerra en contra de la industria farmacéutica. Realmente se trata de una lucha por la vida". Traducción libre de: "A produção local de muitos dos remédios usados no coquetel anti-Aids não é uma declaração de guerra contra a indústria das drogas, é simplesmente uma luta pela vida."

${ }^{4}$ Bajo el artículo 31 del ADPIC, se "permite otros usos de la materia de una patente sin autorización del titular de los derechos, incluido el uso por el gobierno o por terceros autorizados por el gobierno". Esta disposición posibilita que las reglas de propiedad que rigen a las patentes, en la que el titular tiene un derecho a impedir el uso dotado por el ius prohibendi se conviertan en reglas de responsabilidad, en la que el titular tiene el derecho a una compensación por el uso de la invención protegida.

${ }^{5}$ Artículo 65.- Previa declaratoria de un País Miembro de la existencia de razones de interés público, de emergencia, o de seguridad nacional y sólo mientras estas razones permanezcan, en cualquier momento se podrá someter la patente a licencia obligatoria. En tal caso, la oficina nacional competente otorgará las licencias que se le soliciten. El titular de la patente objeto de la licencia será notificado cuando sea razonablemente posible. La oficina nacional competente establecerá el alcance o extensión de la licencia obligatoria, especificando en particular, el período por el cual se concede, el objeto de la licencia, el monto y las condiciones de la compensación económica notificada cuando sea razonablemente posible. La oficina nacional competente establecerá el alcance o extensión de la licencia obligatoria, especificando en particular, el período por el cual se concede, el objeto de la licencia, el monto y las condiciones de la compensación económica.
} 


\section{Cultivando las semillas de la controversia.}

En la presente tesis desarrollaremos argumentos que contribuyen a una visión más allá de las fronteras de la competencia como tal, advirtiendo los beneficios del sistema de patentes para incentivar la innovación. Daremos un breve repaso al origen y la discusión alrededor a la adopción del sistema de propiedad intelectual y analizaremos los costos de los medicamentos como consecuencia de la protección otorgada por las patentes. Además, pondremos en la mesa argumentos a tomar en cuenta para la eventual adopción de la primera licencia obligatoria en el Perú por motivos de salud pública y los efectos de una imposición abusiva de ésta. Se abordará las preocupaciones directamente relacionadas a este dispositivo como los pasos previos a seguir y las distintas alternativas existentes a la licencia obligatoria entre otros aspectos. ${ }^{6}$

Resulta prudente advertir al lector que exclusivamente se ha analizado las licencias obligatorias por interés público, específicamente en el sector farmacéutico dejando de lado las licencias obligatorias por prácticas anticompetitivas, falta de explotación o por dependencia de una patente de un tercero. El presente trabajo se encuentra enfocado en advertir los beneficios y consecuencias de una eventual adopción de este tipo de licencias con el fin de contribuir al debate público y crítica fundamentada. De ningún modo pretendo convencer al lector de adoptar la posición expuesta respecto del régimen de propiedad intelectual o de las licencias obligatorias, ni es mi intención dar un enfoque completo de la situación actual. El objetivo de la presente tesis es dar a conocer los principales aspectos a tomar en consideración en caso el gobierno se vea obligado a adoptar una licencia obligatoria por razones de interés público.

Por último, es necesario señalar que la materia tratada presenta una complejidad por el uso de razonamientos económicos y sociales que deben ir de la mano con criterios legales. A pesar de encontrarnos en un entorno jurídico, se requiere un enfoque

\footnotetext{
${ }^{6}$ Algunos autores han señalado que hay mecanismos más adecuados a la licencia obligatoria como patents pools, crowfunding, entre otros.
} 
multidisciplinario para poder advertir las contingencias de la materia en discusión.

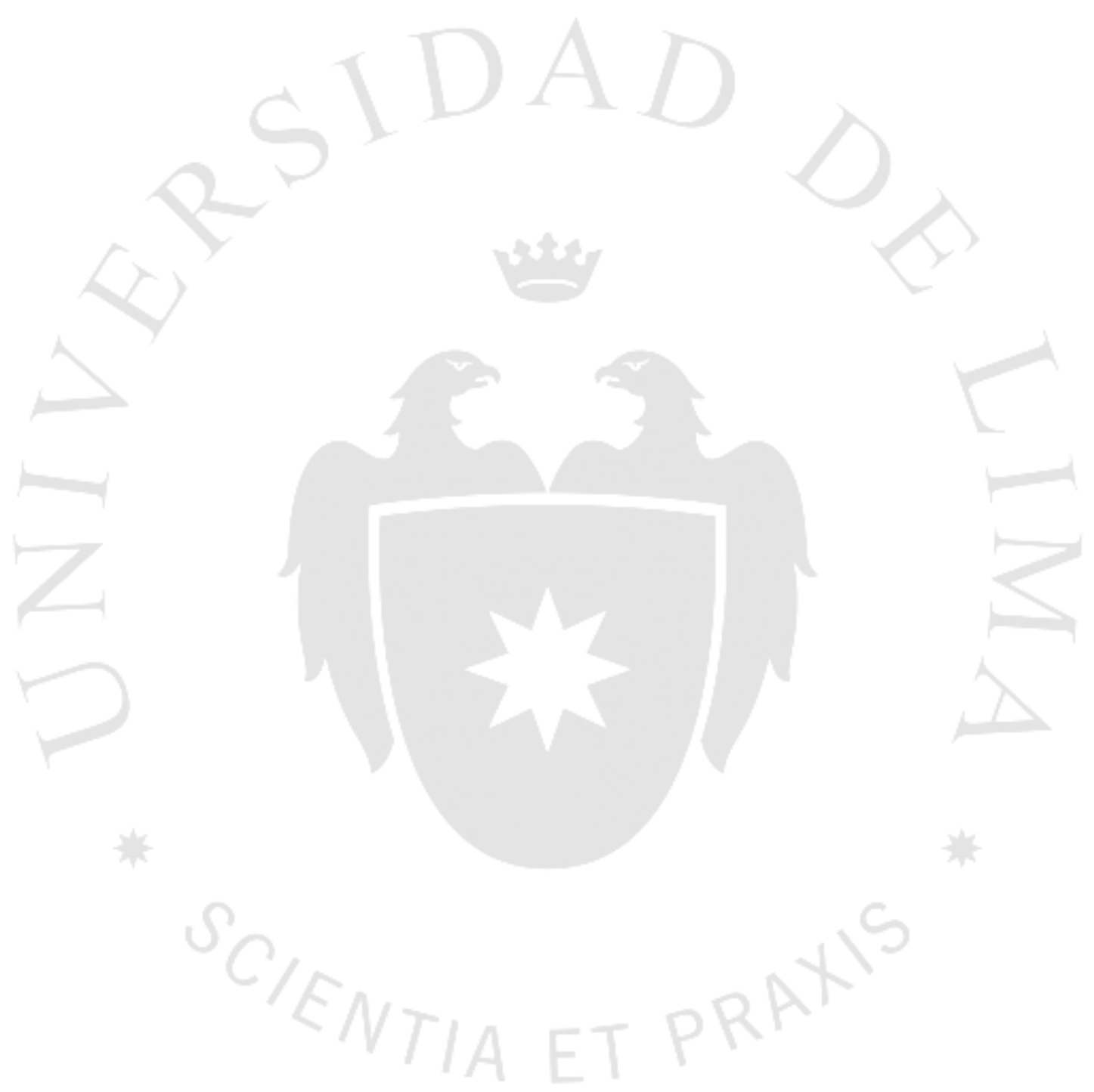




\section{CAPÍTULO I: EVOLUCIÓN HISTÓRICA DEL SISTEMA DE PROPIEDAD INTELECTUAL ACTUAL}

Los primeros privilegios de los que se tiene constancia en la protección de derechos de propiedad intelectual constituyen en realidad privilegios de introducción de industria, esto es, monopolios para el ejercicio exclusivo de una determinada actividad industrial en un territorio. Existe unanimidad a la hora de señalar que el primer privilegio literario se concedió en Venecia a Giovanni di Spira en 1469 por un plazo de cinco años al introducir la imprenta. Según Franceschelli (Franceschelli, 1960, pág. 338), se trata de un privilegia pro arte introducenda, concedido como una especie de premio por ser el primero en introducir un tipo de industria en el Estado, y que vendría a ser lo que en Derecho español constituían las desaparecidas patentes de introducción de industria (Miro Llinares, 2007).

En una época de conflictos políticos y religiosos, el Estado verá en la amplia difusión de ideas un peligro, y tratarán de protegerse con todos los medios, otorgando los privilegios de imprenta como medio de control de los contenidos (Baylos Corroza, 1993, pág. 154). Así se forma el sistema de las licencias reales, concedidas a los editores para la impresión de una obra o varias del mismo tipo o autor, siempre que no fueran contrarias a las ideas políticas, y sobre todo religiosas, que imperaban en el gobierno. (Miro Llinares, 2007).

Debido a la rápida recuperación de la inversión en la impresión de las obras, se permite que el autor negocie con el editor la venta de la obra, lo que originó que a finales del siglo XVII prolifere en toda Europa la concesión directa de privilegios a los autores, y comienzan a aparecer normas ${ }^{7}$ que relacionan la concesión de privilegios al editor con la obtención por éste del permiso del autor (Miro Llinares, 2007). En Inglaterra, el conflicto entre la entidad pública encargada de la concesión de los privilegios

\footnotetext{
${ }^{7}$ En 1544 en Venecia, encontramos la primera norma que prohíbe con carácter general, la impresión y venta de libros si no se acreditaba el consentimiento del autor o sus herederos más próximos.
} 
denominada Stationer's Company y los que solicitaban libertad de impresión impulsó la promulgación del "Estatuto de la Reina Ana" en 1710, el cual estableció el copyright durante catorce años, el derecho por el cual el autor era el único que tenía el derecho de copia de su obra. Se trata, pues, de la primera norma que reconoce al autor, no por privilegio sino por ley, el derecho exclusivo comercializar su obra, y su finalidad, según se deduce del mismo título, era estimular el fomento del arte, de la literatura y de la ciencia mediante la concesión al autor de la exclusiva de impresión (Boytha, 1992).

Así pues, también en España, Francia y Alemania se emitieron decretos que otorgaban derechos exclusivos de reproducción y representación a los autores (Blackstone, 1979). Conforme la imprenta y los derechos de autor iban proliferando, las naciones europeas buscaron protección extraterritorial por lo que iniciaron relaciones entre ellas para tratar de que los titulares de los derechos de propiedad intelectual fueran respetados en cada país como en el suyo propio (Forns, 1951). España fue uno de los primeros países que logró tratados internacionales que protegían los derechos de autor fuera de suelo español, por intermedio de tratados con Francia, Portugal, Reino Unido Países Bajos entre otros países.

Sin embargo, ello no fue suficiente, lo que originó la necesidad de una armonización de derechos de autor a nivel multilateral. Por ello, la Asociación Literaria y Artística Internacional (ALAI) fue redactando un proyecto tipo que dio lugar el 9 de septiembre de 1886 a la fundación de la "Unión Internacional para la Protección de Obras Literarias y Artísticas” o "Convenio de Berna” (Fernandez Shaw, 1975).

La necesidad de protección internacional de los inventos se hizo patente en 1873, con ocasión de la Exposición Internacional de Invenciones de Viena, a la que se negaron a asistir algunos expositores extranjeros por miedo a que les robaran las ideas para explotarlas comercialmente en otros países (OMPI, 2016). Así, el gobierno Austriaco protegió temporalmente los inventos de los extranjeros que participaron en dicha exhibición, y en el mismo año se convocó el Congreso de Viena para la Reforma de Patentes. Pocos años después, en 1878 se convocó en París un congreso para determinar las bases legales de un sistema uniforme de Propiedad Industrial, lo que dio lugar a la 
Convención de París de 1883.

Tanto el Tratado de Berna como el Convenio de París fueron administrados por el Gobierno Suizo, y cada tratado contaba con departamentos independientes. En 1893 ambas oficinas se fusionaron para crear el BIRPI (United International Bureaux for the Protection of Intellectual Property) (Marquez, 2004). Al entrar en vigor el Convenio que establece la Organización Mundial de la Propiedad Intelectual, las BIRPI se convierten en la OMPI, una nueva organización intergubernamental con sede en Ginebra, en la que la iniciativa la llevan sus Estados miembros (OMPI, 2016).

Desde entonces la OMPI ha sido el estandarte de la protección de la propiedad industrial, con el objetivo de reducir las distorsiones del comercio internacional y los obstáculos del mismo. La finalidad de la protección de los derechos intelectuales no es proteger el interés particular de un determinado sector o individuo, sino aumentar los niveles de vida, acrecentar la producción y el comercio de bienes y servicios.

\subsection{La propiedad intelectual a la luz de la OMC.}

El desarrollo de la propiedad intelectual no ha sido exclusivo de la OMPI. Uno de los principales tratados sino el más importante es el Acuerdo sobre los Aspectos de los Derechos de Propiedad Intelectual relacionados con el Comercio (Acuerdo sobre los ADPIC).

Antes de que existiera la Organización Mundial del Comercio -OMC- existía el GATT. El GATT era el Acuerdo General sobre Aranceles Aduaneros y de Comercio, por el cual un grupo de países que se reunía para negociar aranceles, eliminar barreras comerciales y resolver conflictos internacionales en función del principio de reciprocidad.

Desde su creación, el GATT ha celebrado periódicamente Rondas de Negociaciones Multilaterales, centrándose en su mayoría en el tema de la disminución de 
los niveles de protección arancelaria. En la Ronda de Tokio se constató que era necesario iniciar una Ronda respecto de una mayor liberalización y expansión del comercio. El primer intento de traslado de la propiedad intelectual fuera de la OMPI se discutió en la Ronda de Tokio. En aquella oportunidad Estados Unidos impulsó una iniciativa para regular el comercio de mercancías falsificadas, sin embargo no tuvo buena acogida (Franjola, 2009).

La Ronda Uruguay constituyó nuevos lineamientos para la transformación de las reglas que guiaban el régimen internacional de comercio adecuándola a la realidad de la economía internacional. A los tradicionales temas, se sumaron tres nuevos temas conflictivos: (i) servicios, (ii) aspectos de la Propiedad Intelectual vinculados al comercio (ADPIC) y (iii) aspectos de inversión relacionados con el comercio (TRIM'S) (Kresalja, 1994).

El resultado final de la Ronda Uruguay fue el anexo IC del Acuerdo que establece la Organización Mundial del Comercio de 1994, que incorporó un nuevo, amplio y relativamente elevado conjunto de normas mínimas internacionales de protección de la patente, que es lo que conocemos como ADPIC. ${ }^{8}$

La Ronda Uruguay y los $\mathrm{ADPIC}^{9}$ no han hecho sino reconocer que el factor conocimiento será determinante en las transacciones del futuro, y los países que producen y controlan los avances tecnológicos serán los que se verán comercialmente beneficiados.

\footnotetext{
${ }^{8}$ El Acuerdo sobre los ADPIC, que entró en vigor el 1 de enero de 1995, es hasta la fecha el acuerdo multilateral más completo sobre propiedad intelectual. Los ADPIC permiten a los Miembros prestar una protección más amplia a la propiedad intelectual si así lo desean. Se les deja libertad para determinar el método apropiado de aplicación de las disposiciones del Acuerdo en el marco de sus sistemas y usos jurídicos.

${ }_{9}$ El Acuerdo sobre los ADPIC estipula que su objetivo es "reducir las distorsiones y los obstáculos al comercio internacional, y teniendo en cuenta la necesidad de fomentar una protección eficaz y adecuada de los derechos de propiedad intelectual, y para asegurar que la medida y los procedimientos para hacer cumplir la propiedad intelectual derechos no se conviertan en obstáculos al comercio legítimo". Por otra parte, el artículo 7 define el objetivo del Acuerdo sobre los ADPIC: es el de contribuir a la promoción de la innovación tecnológica (...) de modo que favorezcan el bienestar social y económico, y el equilibrio de derechos y obligaciones. "El objetivo general es claramente la protección de los derechos de propiedad intelectual. Sin embargo, los principios del artículo 8 definen las situaciones en las que los miembros del Acuerdo sobre los ADPIC pueden "adoptar las medidas necesarias para proteger (...) y promover el interés público", siempre y cuando las medidas sean compatibles con el Acuerdo.
} 
La posición competitiva será determinada por el grado de desarrollo tecnológico y creación de innovaciones (Kresalja, 1994).

\subsubsection{La posición de los países sobre la regulación de propiedad intelectual.}

Las posiciones de los países en las negociaciones de la Ronda Uruguay no fueron convergentes. De un lado, los países desarrollados como Estados Unidos lideraron la inclusión de los derechos de propiedad intelectual. Por el otro lado, los países en vías de desarrollo sostuvieron una postura restrictiva de los derechos intelectuales. Asimismo, señalaban que era necesario estudiar el impacto que el incremento de la protección podría provocar en la economía local y global. Brasil e India fueron los países que lideraban a los países en vías de desarrollo, los cuales trataban de evitar la perpetuación creciente de la desigualdad comercial.

\section{- Estados Unidos.}

En 1986, la Oficina de Asesoría de Tecnología del Congreso de los Estados Unidos, en adelante la OTA, publicó el informe "Intellectual Property Rights in an Age of Electronics and Information" (Congreso de los Estados Unidos - Oficina de Asesoría Tecnologica, 1986), el cual señala que es necesario efectuar un cambio radical en materia de propiedad intelectual. Dichas leyes o políticas deben responder y tener en cuenta lo siguiente: (i) que la información es tanto un bien transable como un recurso social, difícil de controlar pero fácil de copiar; (ii) la creciente complejidad del sistema de protección de la Propiedad Intelectual; y, (iii) la naturaleza cambiante de la tecnología, lo que creó creciente incertidumbre al inicio de la era electrónica. Concluye que los Estados Unidos deben utilizar diversos mecanismos para lograr el difícil balance entre los intereses públicos y privados, y hacer que la política que se adopte en materia de Propiedad Intelectual tenga un efecto positivo en el nivel de vida y en el status de la gente (Congreso de los Estados Unidos - Oficina de Asesoría Tecnologica, 1986).

Asimismo, para conocer la posición de los Estados Unidos en el GATT, es necesario revisar el documento denominado "General Accounting Office" del Departamento de Seguridad y Asuntos Internacionales, el cual indica que la piratería a 
corto plazo reduce el retorno de la inversión, disminuye ventas, utilidades y puestos de trabajo, mientras que a largo plazo, debilita los sistemas internacionales a fomentar la innovación y creatividad (USA Government Accountability Office, 1987). Dichos argumentos empujaron la negociación dando inicio al establecimiento del sistema de propiedad intelectual.

En síntesis, Kaplinsky (Kaplinsky, 1988) señala que las propuestas de Estados Unidos en el GATT con respecto al ADPIC fueron las siguientes:

- La creación de controles fronterizos y la adopción de sanciones para los transgresores.

- El desarrollo de patrones nacionales que resguarden los Derechos Intelectuales.

- La adopción de medidas para que los "nuevos" derechos intelectuales no constituyan un obstáculo para el comercio; y,

La provisión de procedimientos para la solución de controversias.

- Países en desarrollo.

En la negociación de los ADPIC los países en desarrollo indicaron que si bien los Derechos Intelectuales equilibran los costos sociales, el conocimiento divulgado por las patentes puede ser utilizado como insumo para crear mayor conocimiento. Así pues, sin la protección de los derechos de propiedad intelectual los países emergentes tenían la posibilidad de desarrollarse asimilando el conocimiento y tecnología de los países del primer mundo. ${ }^{10}$

Si bien los países en desarrollo indicaban que en la teoría los derechos intelectuales equilibran los costos sociales a corto plazo con los beneficios a largo plazo, ello ocurre en un sistema casi cerrado, en el cual los beneficios se distribuyen en forma desigual para los países. Más aún si el gran número de patentes provienen de los países

\footnotetext{
10 Durante la mayor parte del siglo XIX, Estados Unidos no concedió el "copyright" a los autores extranjeros argumentando que necesitaba libertad de copia para educar a una nueva nación. De forma similar, países europeos, como Suiza, construyeron sus bases industriales copiando las invenciones de otros, un modelo que fue seguido tras la segunda Guerra Mundial por Taiwán y Corea del Sur.
} 
desarrollados, ${ }^{11}$ en consecuencia, dichos beneficios serán trasladados de forma casi exclusiva a los países industrializados (Kresalja, 1994). Asimismo, se argumentó que la excesiva protección de la propiedad intelectual disminuye la competencia, de tal forma que los innovadores descuidan las ventajas comparativas que los mantiene vigentes en el mercado frente a los imitadores: reputación, calidad y continuas mejoras técnicas.

Por último, países como Brasil e India rechazaron los ADPIC por el hecho que trata a los medicamentos como a cualquier otro bien, lo cual puede tener un impacto negativo sobre el acceso a los mismos debido a que el monopolio otorgado por una patente le permite a la industria farmacéutica fijar altos precios que pueden afectar el acceso a los medicamentos principalmente entre la población con menos recursos.

En resumen, las principales preocupaciones de los países en desarrollo fueron: (i) los derechos de propiedad intelectual pueden ralentizar el ritmo general de la innovación dado que el conocimiento es un insumo clave en la producción de más conocimiento. Por tanto, existe la preocupación de que el ritmo de la imitación de los países en vías de desarrollo pueda ser más lento, y la brecha de conocimientos entre los países industrializados y en desarrollo puede aumentar; y, (ii) el costo de adquisición de conocimientos será más alto lo que conduce a un mayor poder de negociación de los productores de conocimiento dejando un margen menor a los países usuarios.

\subsubsection{Inclusión de los países en desarrollo en el acuerdo ADPIC.}

Los países desarrollados liderados por Estados Unidos ofrecieron facilidades para el ingreso y comercio en sus mercados a cambio de que los países en desarrollo ofrezcan protección extraterritorial $^{12}$ de los derechos de propiedad intelectual.

Ahora bien, aunque los países en desarrollo se oponían a la inclusión de la protección de los derechos de propiedad intelectual en los inicios de la Ronda de

\footnotetext{
${ }^{11}$ Los países industrializados detentan el $97 \%$ de todas las patentes del mundo según el Informe sobre Desarrollo Humano 1999.

${ }^{12}$ Los derechos de la Propiedad intelectual terminaban después de cierto plazo, finalización que siempre ha tenido carácter territorial.
} 
Uruguay, al final, su resistencia fue superada por el temor a las sanciones de las que podrían ser objeto si no estaban preparados para incorporar los nuevos estándares de protección. Dichos países consideraron que aunque el acuerdo sobre los ADPIC iba en contravía de sus intereses, todo el paquete que ofrecía los países desarrollados compensaría el alto costo social y económico que podía representar su inclusión, así que, a juicio de algunos autores, los países en desarrollo simplemente escogieron entre dos males el menor (ICTSD-UNCTAD) citado por (Oñate, 2010).

Es así que, los países en desarrollo aceptaron su incorporación al sistema de patentes, ${ }^{13}$ a cambio de un mayor acceso a los mercados desarrollados para los productos manufacturados tradicionales más un compromiso de los países desarrollados para detener la imposición de sanciones comerciales unilaterales por la inadecuada protección de los derechos de propiedad industrial (Reichman, 2009).

Del mismo modo, muchas naciones en desarrollo fueron obligadas a revisar sus legislaciones nacionales para extender la protección concedida por el derecho de patentes a los productos farmacéuticos (ICTSD-UNCTAD). Con la finalidad de minimizar los efectos negativos de la protección de patentes principalmente en el acceso a los medicamentos se logró incluir en los ADPIC flexibilidades y salvaguardas para proteger la salud pública (Klein, 2011). El capítulo siguiente muestra las principales disposiciones de los ADPIC relacionadas con las políticas de medicamentos y abuso de los derechos de propiedad intelectual.

Por ejemplo, en el mismo Artículo 8 del Acuerdo sobre los ADPIC inclina la balanza de manera equitativa para los países en desarrollo confiriéndoles el derecho a:

(i) Adoptar las medidas necesarias para proteger la salud pública y la nutrición de la población, o para promover el interés público en sectores de importancia vital para

\footnotetext{
${ }^{13}$ El artículo 27 de ADPIC referido a materia patentable establece lo siguiente: "Sin perjuicio de lo dispuesto en los párrafos 2 y 3 , las patentes podrán obtenerse por todas las invenciones, sean de productos o de procedimientos, en todos los campos de la tecnología, siempre que sean nuevas, entrañen una actividad inventiva y sean susceptibles de aplicación industrial”.
} 
su desarrollo socioeconómico y tecnológico, siempre que esas medidas sean compatibles con lo dispuesto en el presente Acuerdo.

(ii) Prevenir el abuso de los derechos de propiedad intelectual por sus titulares o el recurso a prácticas que limiten de manera injustificable el comercio o redunden en detrimento de la transferencia internacional de tecnología.

En este sentido, las negociaciones estuvieron encaminadas la promoción del acceso de todos a los medicamentos y la garantía de condiciones que aseguren que se disponga de nuevos medicamentos en el futuro, así como de la prevención de cualquier abuso en el otorgamiento de derechos de propiedad intelectual (Oñate, 2010).

De esta manera, a pesar de las evidentes tensiones que caracterizaron sus inicios, el Acuerdo sobre los ADPIC constituyó el primer hito en la era de globalización de la propiedad intelectual al legitimar y difundir reglas homogéneas sobre el tema que han facilitado su aplicación general, gracias a dos características relevantes: la primera de ellas es que unifica en un solo texto los temas de propiedad industrial y los derechos de autor, que antes se regían separadamente mediante el Convenio de París y la Convención de Berna, en un esfuerzo de armonización sin precedentes históricos en cuanto a amplitud y profundidad (Diaz) citado en (Oñate, 2010); la segunda característica a destacar es que como hace parte integrante de la Organización Mundial del Comercio, su administración no depende de una entidad especializada como la OMPI, carente de facultades para imponer sanciones económicas, sino que está sometido a los mismos procedimientos de solución de controversias y aplicación de sanciones que el resto de las disciplinas comerciales (Oñate, 2010).

El acuerdo ADPIC, aprobado el 15 de diciembre de 1993, se encarga de plasmar en un documento único los paradigmas de los Estados parte de la negociación, el cual tiene por objetivo lograr un equilibrio entre la protección del titular de los derechos de propiedad intelectual y la función social que debe cumplir al promover la innovación 
(Franjola, 2009, pág. 8).

El Acuerdo sobre los ADPIC está dividido en siete partes, compuestas por 73 artículos. La segunda parte contiene los elementos más importantes para la salud pública, especialmente en lo que se refiere al acceso a los medicamentos. Los temas tratados en esa sección incluyen: derechos de autor y derechos relacionados, marcas registradas, indicaciones geográficas, diseños industriales, patentes, diseños de circuitos integrados, protección de información confidencial y control de prácticas anticompetitivas en licencias contractuales (Bermudez, 2006).

\subsection{Todos los caminos llevan a Doha.}

Las patentes sobre los productos farmacéuticos son, tal vez, como ningún otro, el tema más mediático y controversial de la era post ADPIC, situación que ha permitido evidenciar con gran detalle las dificultades de interpretación de este acuerdo y los problemas para conciliar los intereses de la industria farmacéutica con los de los países pobres sin capacidad económica para acceder a medicamentos para su población (Oñate, 2010, pág. 134).

En 1999, el Informe sobre Desarrollo Humano del Programa de las Naciones Unidas para el Desarrollo hizo un llamado para que se considere una revisión de los ADPIC contemplando las reglas de la globalización y desarrollo sostenible: "para las personas y no sólo para las empresas" (T’hoen, 2002, pág. 49).

El debate sobre los ADPIC y la salud pública comenzó en la OMC en 1999 en la reunión ministerial de Seattle. En la Conferencia de Seattle la Comisión Europea junto a otros países preparó un documento de trabajo, el cual propone que se permita a los países en desarrollo emitir licencias obligatorias para los medicamentos que figuran en la lista de medicamentos esenciales de la Organización Mundial de la Salud. Sin embargo, lejos de convertirse en una herramienta útil para superar la barrera de acceso a los medicamentos ello podría tener el efecto contrario puesto que podría restringir las licencias a determinados productos (T'Hoen, The global politics of pharmaceutical 
monopoly power, 2009, pág. 20).

En el período transcurrido entre la Conferencia Ministerial de la OMC de Seattle y la reunión de la OMC de 2001 en Doha se produjo una vorágine de acontecimientos que tuvieron un profundo efecto en el debate sobre el acceso a los medicamentos y la propiedad intelectual. A decir de Correa y Velásquez en (Bermudez, 2006), el primero fue la percepción de que la combinación de la competencia con productos genéricos, el trabajo de defensa y las disposiciones legales relacionadas con las salvaguardias del Acuerdo sobre los ADPIC habían tenido un importante efecto en el precio de los medicamentos como se evidenció en la dramática reducción de precios de más del $95 \%$ en el costo indicativo anual de la triple terapia del esquema antirretroviral en Sudáfrica, pasando de US $\$ 10.000$ en 1996 a US \$140. Esa percepción fue posteriormente confirmada por ocasión de la negociación de Brasil, después de la amenaza de emitir una licencia obligatoria sobre las patentes de antirretrovirales. Por último, el hecho que los Estados Unidos y Canadá hayan amenazado emitir una licencia obligatoria contra la compañía alemana Bayer, productora de la Ciprofloxacina, durante el pánico del ántrax y su uso en el terrorismo biológico, aunado a los acontecimientos detallados a continuación contribuyeron a la emisión de la Declaración de Doha tal y como se le conoce hoy en día.

\subsubsection{Big Pharma vs. Mandela.}

"Sabemos que sin una mayor ayuda, 23 millones de personas estarán al borde de la muerte. No hacer nada es participar en un genocidio" Cornelius Baker, Clínica Walker Whitman

Sudáfrica 1999 (BBC): Todos los días se contagian unas 1500 personas con el virus de inmunodeficiencia humana, el VIH, sumándose así a los cuatro millones ya infectados. No hay indicio de que el índice de contagio vaya a disminuir.

La nota de la BBC describe perfectamente el holocausto generado por el SIDA lo que llevó a que el Presidente Mandela suscribiera la Ley de Enmienda Sudafricana de 
Control de Medicamentos y Substancias Relacionadas (Medicines Act 90/1997). La Asociación de Fabricantes de Productos Farmacéuticos de Sudáfrica, en conjunto con 39 empresas farmacéuticas multinacionales, instauraron un proceso contra el Gobierno de la República Sudafricana en la Corte Suprema de Pretoria, alegando que dicha ley violaba el Acuerdo sobre los ADPIC y la Constitución de ese país. Los procedimientos litigiosos resultaron en la inmediata suspensión de la Ley en cuestión (Bermudez, 2006).

La Ley de Medicamentos de 1997 introdujo un marco legal para aumentar la disponibilidad de medicamentos asequibles en Sudáfrica. Las disposiciones incluían la sustitución con medicamentos genéricos de los fármacos con patentes vencidas, la regulación de precios y la importación paralela de medicamentos patentados.

Estados Unidos y la Unión Europea amenazaron a Sudáfrica con sanciones comerciales si no revocaba la Enmienda que era lesiva para los intereses comerciales de sus empresas a pesar que la norma en cuestión no era contraria a los ADPIC. Debido a la presión de las ONGs y la fuerte indignación pública internacional, el gobierno de Estados Unidos se vio forzado a cambiar de posición. Durante el juicio se puso de manifiesto que la parte más controversial de la Ley se basaba en un proyecto elaborado por el Comité de Expertos de la OMPI, hecho que sumado a la presión pública ${ }^{14}$ logró que las compañías demandantes desistieran de la demanda en 2001 (T’Hoen, 2002).

\subsubsection{Programa Nacional DST/SIDA - Brasil.}

Desde mediados de los años noventa, Brasil ha ofrecido atención integral contra el SIDA, ${ }^{15}$ incluido el acceso universal al tratamiento antirretroviral. En 2001, 105.000 personas con VIH/SIDA recibieron tratamiento gracias a los medicamentos genéricos producidos localmente. El programa brasileño de SIDA ha reducido la mortalidad relacionada con el SIDA en más de un 50 por ciento entre 1996 y 1999.

\footnotetext{
${ }^{14}$ Uno de los principales argumentos utilizados por los activistas fue que 400.000 personas habían fallecido durante el período de suspensión de la enmienda por falta de recursos para pagar el tratamiento.

${ }^{15}$ La ley federal $n^{\text {o }} 9.313 / 1996$ tornó obligatoria la distribución de medicamentos antirretrovirales por el sistema público de salud debido a la fuerte epidemia de SIDA que venía asolando el país. La mencionada Ley garantiza a los pacientes el acceso universal a los antirretrovirales y a otros medicamentos relacionados.
} 
El programa se vio amenazado por la sostenibilidad financiera del Programa Nacional DST/SIDA, ello debido a que los medicamentos antirretrovirales de primera línea producidos localmente no estaban bajo la protección de patentes en Brasil, pues en la época en que tuvo inicio la producción, el país no reconocía las patentes farmacéuticas (Klein, 2011, pág. 41). El gobierno brasileño tuvo que buscar alternativas para costear el Programa Nacional para la lucha contra el VIH/SIDA ante los altos precios de los nuevos medicamentos protegidos por los ADPIC y la nueva normativa nacional. Por ello, el empleo de la licencia obligatoria como mecanismo para negociar una reducción de precios de los productos patentados ha sido utilizado numerosas veces por el Departamento de Salud de Brasil.

El éxito de las negociaciones del gobierno brasileño con los laboratorios multinacionales detentores de las patentes farmacéuticas reside en la capacidad para fabricar los medicamentos a nivel local gracias al desarrollo del programa "Brasil contra el SIDA”, el cual sirve de modelo para algunos países en desarrollo. El gobierno de Brasil a través de su programa ha ofrecido un acuerdo de cooperación, incluida la transferencia de tecnología, a los países en desarrollo para la producción de medicamentos antirretrovirales genéricos (Klein, 2011).

En febrero de 2001, Estados Unidos presentó una denuncia contra Brasil ante el Órgano de Solución de Diferencias de la OMC por el artículo 68 de la ley brasileña de propiedad intelectual. En virtud de esa disposición, Brasil exige a los titulares de patentes brasileñas que fabriquen el producto en territorio brasilero, lo que se denomina requisito de "trabajo local". Si la empresa no cumple con este requisito, la patente estará sujeta a licencias obligatorias después de tres años, a menos que el titular de la patente pueda demostrar que no es económicamente viable producir en Brasil o puede demostrar que el requisito de producir localmente no es razonable (T’hoen, 2002, pág. 33). El 25 de junio de 2001, en una declaración conjunta con Brasil, Estados Unidos anunció el desistimiento de la demanda ante la OMC debido a las fuertes presiones internacionales de los activistas de las ONGs, quienes argumentaban que una decisión desfavorable contra Brasil podría impactar negativamente la continuidad del Programa Nacional de SIDA (Cooper, 2001). 


\subsection{Conferencia Ministerial de Doha.}

La Cuarta Conferencia Ministerial de la OMC tuvo lugar en Doha en 2001 y fue un avance en las discusiones internacionales sobre los ADPIC y el acceso a los medicamentos. La Conferencia Ministerial de la OMC adoptó una Declaración sobre los ADPIC y la Salud Pública, que anteponía la salud pública a los intereses comerciales y ofrece una clarificación muy necesaria en el ámbito de los ADPIC y la salud pública.

Asimismo, la Declaración reconoce la gravedad de la crisis de salud pública que afecta a la mayoría de los países en desarrollo, especialmente en lo que se refiere a VIH/SIDA, tuberculosis y malaria, entre otras enfermedades. La Declaración refleja también las preocupaciones de los países en desarrollo relativas al Acuerdo sobre los ADPIC y la salud pública.

El párrafo 4 de la Declaración reafirma los principios expresados en el artículo 8 del Acuerdo sobre los ADPIC y enfatiza que el acceso a los medicamentos es un importante componente de las políticas de salud:

"Convenimos en que el Acuerdo sobre los ADPIC no impide ni deberá impedir que los Miembros adopten medidas para proteger la salud pública. En consecuencia, al tiempo que reiteramos nuestro compromiso con el Acuerdo sobre los ADPIC, afirmamos que dicho Acuerdo puede y deberá ser interpretado y aplicado de una manera que apoye el derecho de los Miembros de la OMC de proteger la salud pública y, en particular, de promover el acceso a los medicamentos para todos. A este respecto, reafirmamos el derecho de los Miembros de la OMC de utilizar, al máximo, las disposiciones del Acuerdo sobre los ADPIC, que prevén flexibilidad a este efecto".

El principal motivo de discusión en Doha ha estado relacionado con la disposición del apartado f) del artículo 31 del acuerdo sobre los ADPIC según la cual los miembros deben asegurar que las licencias obligatorias deben ser utilizadas para el abastecimiento del mercado interno. Por ello, se discutió si los países con posibilidades de exportación 
de medicamentos podrían conceder una licencia obligatoria para responder a problemas de salud pública en otro país que no tiene la experiencia ni la tecnología para producir medicamentos, a pesar de contar con la posibilidad de otorgar una licencia obligatoria, y limitarse a importar productos de países donde los productos farmacéuticos no estén patentados, o donde las patentes han caducado (Correa, 2002, pág. 1).

Para resolver lo anterior, el párrafo 6 de la Declaración, encomendó a los Miembros de la OMC encontrar una solución que les permitiera a los países que no fueran capaces de fabricar por sí mismos los productos farmacéuticos, importar medicamentos patentados fabricados al amparo de licencias obligatorias sin que por ello se considere que desconocen las disposiciones del acuerdo.

Por otro lado, en la Declaración de Doha relativa a los ADPIC se aclaró que todos los miembros tienen derecho a otorgar licencias obligatorias y son libres para determinar de manera subjetiva las bases para concederlas, lo cual puede alentar a los países a emitir licencias obligatorias sin preocupaciones de reacción política.

Además, se confirmó el derecho de los países a determinar lo que constituye una emergencia nacional u otras circunstancias de extrema urgencia, en cuyo caso se puede obviar el requisito de solicitar previamente la autorización del titular de la patente para utilizar la invención patentada en términos y condiciones comerciales razonables.

Sin perjuicio de los beneficios que la Declaración conlleva, la potestad otorgada a los miembros de la OMC para definir los escenarios de emisión de una licencia obligatoria es demasiado amplia y subjetiva. La consecuencia de una disposición de este tipo es la posibilidad de que los países puedan otorgar una licencia obligatoria bajo aspectos subjetivos sin parangón alguno. El mencionado texto del Acuerdo sobre los ADPIC carece de pautas objetivas y, por lo tanto, puede contribuir a crear un ambiente para abusos de otorgamiento de licencia obligatoria alrededor del mundo. 


\section{CAPÍTULO II: VENTAJAS Y DESVENTAJAS DEL SISTEMA DE PATENTES DE INVENCIÓN}

La patente de invención es un título que otorga el Estado a una persona por un tiempo establecido (normalmente 20 años) para que pueda explotar de manera exclusiva su invención dentro de un territorio determinado, la misma que debe estar dotada de novedad, altura inventiva, aplicabilidad industrial.

Sin embargo, la protección de las patentes como mecanismo para impulsar la innovación y la transferencia de tecnología, ha sido objeto de amplios e históricos debates, que giran en torno a defenderlas con el fin de incentivar la investigación, el desarrollo y la transferencia de tecnología, o rechazarlas por considerarlas monopolios legales que crean escasez artificial, anulan la libre competencia y reducen las posibilidades de superación de la pobreza y el subdesarrollo (Rodriguez Spinelli, 2008, pág. 87).

\subsection{Abajo el sistema de patentes. Argumentos en contra del sistema de patentes.}

Tal y como ha sido concebida, la patente es un mecanismo de exclusión a terceros en lo que a la explotación económica del invento se refiere, y para ello, se erige como un monopolio legal, conferido al creador durante un tiempo específico (Rodriguez Spinelli, 2008).

(Bullard, 2006) y (Pasquel, 2004), desde una postura económica, advierten que los monopolios en general y los creados por la propiedad intelectual en particular, son costosos, peligrosos y generan pocos beneficios sociales. Asimismo, advierten que éstos conducen a precios más altos y a menor producción generando incentivos únicamente para la búsqueda de rentas o rent seeking. ${ }^{16}$

${ }^{16}$ Situación que se produce cuando un individuo, organización o empresa busca obtener ingresos captando 
Esta postura es afianzada por (Rubio, 1996) citado por (Rodriguez Spinelli, 2008), quien sostiene que la formación de monopolios permite la obtención de un puesto privilegiado para dominar los mercados, fomentar la concentración y el alza de los precios de los productos o servicios, el entorpecimiento del abastecimiento de los países de mediana tecnología y la protección de los intereses privados. A decir del autor, no cabe esperar que con una protección de patentes más fuerte aumenten las inversiones extranjeras sino todo lo contrario, se aprecia una desinversión acelerada de empresas extranjeras en países que recientemente han optado por proteger las patentes farmacéuticas.

Schumpeter, por el contrario argumentó que si bien el derecho de propiedad intelectual genera un monopolio, ello a su vez genera incentivos para la innovación y así desplazar el monopolio existente creando nuevos nichos de mercado. Este tipo de competencia se denomina “competencia schumpeteriana” (Tavares, 1986, pág. 515).

Sin embargo, Stiglitz considera que el poder de monopolio, una vez establecido, puede fácilmente ser perpetuado. No sólo es posible mantener el poder de monopolio, de hecho existe un incentivo para hacerlo. Esto es particularmente evidente en el caso de externalidades de red y en situaciones en las que hay costes de cambio tecnológicos o de sistema importantes. Es por ello que el monopolio sobre los sistemas operativos de Microsoft es tan difícil de desplazar. Este tipo de poder persiste incluso después de la vigencia de la patente y del cese de las malas prácticas que le han permitido construir dicho monopolio (Stiglitz, 2008, pág. 1705).

Por otro lado, el nobel en economía, Friedrich Hayek en su revolucionario ensayo "La competencia como proceso de descubrimiento" señala que, la imposición del privilegio de monopolio impide que el productor potencial más eficiente del mercado pueda producir a menos precio que los titulares de patentes. Los precios más altos de los

renta económica a través de la manipulación o explotación del entorno político o económico, en lugar de obtener beneficios a través de transacciones económicas y producción de riqueza añadida. 
productos patentados no sólo se dan por el margen de inversión de investigación y desarrollo, sino también por las deficiencias que el titular de la patente no está interesado en cubrir por contar con un monopolio. En este sentido, las empresas innovadoras no tienen estímulos para reducir sus costos, mejorar sus procesos de producción ni de distribución para abastecer a los consumidores de manera eficiente.

Además, el costo por mantener el sistema en funcionamiento resulta muy alto. Los innovadores como el pionero del motor a vapor James Watt, dedicaron enormes cuantías de tiempo y dinero a defender los derechos de patente en vez de destinar el esfuerzo a crear nuevo valor. La historia nos ha demostrado una y otra vez que la innovación y el crecimiento económico prosiguieron rápidamente una vez que las patentes de los inventos más importantes expiraron. En el caso del motor a vapor, la batalla legal por los derechos de la patente retrasó la construcción de locomotoras a vapor así como el crecimiento económico de la revolución industrial (Boldrin \& Levine). Por ello, Boldrin y Levine afirman que la protección de las patentes, se utiliza principalmente como una herramienta para prevenir el progreso económico y herir de muerte a la competencia (Boldrin \& Levine, pág. 3).

Los economistas Becker y Posner advierten que cuando la protección por patentes proporciona al inventor más aislamiento de la competencia de lo necesario con el fin de incentivarlo a realizar el invento, el resultado es el alza de precios por encima de los niveles de eficiencia, lo cual causa distorsiones en la distribución de los recursos: engendra carreras de patentes despilfarradoras porque duplican el esfuerzo y porque son innecesarias para inducir las invenciones (aunque las carreras sí aceleran el paso de las invenciones). Además, incrementa el costo de buscar los registros de patentes con el fin de asegurarse que no se está infringiendo alguna patente con la invención propia, fomenta el registro de patentes defensivas (por anticipación de que alguien más vaya a patentar un producto similar y acusar a uno de infracción) e impulsa los troles de patentes ${ }^{17}$ o por su nombre en inglés, "patent asertion entity" (Hemphill, 2013), que compran grandes números de patentes con el único propósito de obtener dinero amenazando con demandar

17 Trol de patente es un término para hacer referencia a una persona o empresa que impone sus patentes contra uno o más supuestos infractores de una forma considerada excesivamente agresiva $u$ oportunista, a menudo sin la intención de fabricar o comercializar el producto objeto de la patente. 
por un uso no autorizado (Becker \& Posner, 2012).

Por los argumentos señalados anteriormente, los países en desarrollo se oponen a la protección de los derechos de propiedad intelectual resaltando que este tipo de protección limita severamente el motor del crecimiento económico de cualquier nación: la competencia. De hecho, durante la mayor parte del siglo XIX, Estados Unidos no concedió el copyright a los autores extranjeros aduciendo que necesitaba libertad de copia para educar a una nueva nación. De forma similar, países europeos, como Suiza, construyeron sus bases industriales copiando las invenciones de otros, un modelo que fue seguido tras la segunda Guerra Mundial por Taiwán y Corea del Sur (Ortun, 2005).

Por último, una de las críticas más incisivas corresponde a la desproporción de los beneficios otorgados al innovador a cambio de los beneficios sociales marginales. Es decir, el sistema debería poder otorgar un beneficio proporcional al intervalo de tiempo desde el descubrimiento o la invención por parte del innovador hasta que la sociedad lo hubiera hecho.

A cualquiera le hubiera gustado pensar que si uno mismo no hubiera realizado un determinado invento o descubrimiento, nadie más lo hubiera descubierto. La realidad es que alguien más casi con toda seguridad podría haber realizado inventos $o$ descubrimientos similares, tal vez al día siguiente, el próximo mes o el próximo año, o tal vez en diez años, pero habría sucedido con el tiempo. Desde un punto de vista social, la contribución de un innovador es poner a disposición ese conocimiento antes que cualquier persona, y sólo en la medida en que ese conocimiento sea generado antes es que debe ser recompensado. La eficiencia económica requiere que dicha compensación tenga una relación directa con los beneficios sociales marginales. Sin embargo, no es posible determinar el beneficio social marginal de la innovación, por lo que estamos dispuestos a otorgar el valor total de la innovación al "innovador".

El proyecto del genoma humano es un caso en el que existe una clara distinción de la diferencia entre el beneficio total de la innovación y sus beneficios sociales 
marginales. Hubo un gran esfuerzo internacional para decodificar el genoma humano, y por la década de los noventa parecía claro que se llevaría a cabo dentro de los próximos años, lo que ocasionó una carrera entre las empresas. Los privados para completar el proyecto más rápido que los otros, estaban dispuestos a gastar millones de dólares para terminar un día más rápido que sus competidores. ¿Por qué? Si pudieran decodificar el genoma e identificar un gen, por ejemplo el gen del cáncer, recibirían una patente. Eso significaría que cualquiera que quisiera ser examinado para saber si tiene riesgo de contraer cáncer tendría que pagar una enorme cantidad de dinero, ya que el ganador tendría un monopolio sobre la codificación de dicho gen.

La compañía biofarmacéutica Myriad $^{18}$ recibió la patente y ha estado abusando de ella desde entonces cobrando miles de dólares para determinar si una persona tiene probabilidades de tener cáncer, a pesar que las compañías que descifraron el genoma de manera posterior se encontraban dispuestas a realizar pruebas de diagnóstico de forma gratuita. Por supuesto, si uno no tiene el dinero suficiente, es posible que no pueda permitirse el lujo de realizarse dicho examen. Debido a la falta de recursos, muchas personas pueden morir como resultado de no tener la prueba de diagnóstico adecuada. El proyecto del genoma humano tuvo grandes costos sociales, y muy pocos beneficios por una innovación más rápida.

Así como la compañía Myriad ocasionó el estancamiento de nuevos descubrimientos que podrían haberse generado por un libre acceso a la decodificación del genoma humano, existen casos que no puedo dejar de anotar porque a pesar de que su invención ha significado una ruptura de los mecanismos tradicionales de tecnología, son claros ejemplos de cómo la protección de una patente ralentiza el progreso tecnológico de nuestra sociedad.

\subsubsection{Hnos. Wright. Un despegue retrasado.}

El problema fundamental con las patentes es que no puedes delimitarlas, lo cual genera varios problemas de definición. La distribución de la tierra puede ser replanteada y

${ }^{18}$ U.S. Patent No. 5, 747,282. 
determinarse los límites con precisión, y aun así puede haber disputas de límites y/o partidas superpuestas. En cambio, en el sistema de patentes es diferente; es muy difícil saber con precisión lo que este derecho implica, lo que corresponde a otra patente, y lo que es de dominio público. Esto da lugar a batallas legales que frenan la innovación al no permitir a un tercero que "mejore" tu innovación.

Uno de los inventos que revolucionó nuestra sociedad fue el avión. Todo el mundo sabe acerca de los hermanos Wright y su primer vuelo tripulado en Kitty Hawk, Carolina del Norte. Los hermanos Wright obtuvieron una patente primordial sobre el sistema de control de una "máquina de volar", la que no le daba únicamente una protección sobre el sistema que tenían, sino que le otorgaba un monopolio sobre cualquier sistema de estabilidad que pudiera ser construido sobre objeto parecido a un avión. ${ }^{19} \mathrm{Y}$ como pueden imaginarse no dudaron en utilizarla para iniciar demandas contra aquel que se dedique a construir aviones e incluso contra quien realice exhibiciones de los mismos.

La batalla legal más famosa de los hermanos Wright los enfrentó con el aviador estadounidense Glenn Curtiss, quien al diseñar el sistema de alerones que se utiliza hasta el día de hoy, fue acusado de utilizar su sistema de alabeo ${ }^{20}$ patentado poco tiempo antes. Los Wright pretendían que cualquier mejora al sistema de aviación de ese entonces reciba una autorización de su parte. De hecho, Wilbur Wright escribió en una carta: "Es nuestra opinión que moralmente el mundo nos debe enteramente a nosotros la creación del sistema control lateral. Es también nuestra opinión de que legalmente nos pertenece" 21 (Nocera, 2014).

El litigio más importante en la historia de la aviación provocó que el desarrollo de la industria aeronáutica en los Estados Unidos se retrasara seriamente por la existencia

\footnotetext{
${ }^{19}$ Joseph Stiglitz denomina patent thickets o maraña de patentes a la situación en la cual para poder innovar resulta necesario utilizar la patente de un tercero. Por un lado hay que proteger lo que desarrollas pero por otro necesitas acceder a lo que los demás van desarrollando para poder avanzar. Las marañas de patentes no es tema reciente, es problema que se ha suscitado durante largo tiempo.

${ }^{20}$ La técnica del alabeo de los Hermanos Wright consistía en cuerdas atadas a las alas, de las que el piloto podía tirar o soltar por intermedio del timón.

${ }^{21}$ Traducción libre de: "It is our view that morally the world owes its almost universal system of lateral control entirely to us. It is also our opinion that legally it owes it to us."
} 
de una situación caótica en relación con la validez y la propiedad de las patentes aeronáuticas más importantes (Manufacturers Aircraft Association Inc. vs. the United States., 1933). No se sabía a quién se debía pagar para poder desarrollar un avión ya que Glenn Curtis también tenía algunas patentes importantes. Y así, el avión no fue desarrollado hasta la Primera Guerra Mundial, cuando se reconoció que ganar la guerra era más importante que las patentes en disputa. El gobierno de los Estados Unidos otorgó una licencia obligatoria sobre las patentes de Wright-Curtiss y se determinó la cantidad que debía pagarse a cada uno. El desarrollo del avión procedió muy rápidamente a partir de entonces (Manufacturers Aircraft Association Inc. vs. the United States., 1933).

\subsubsection{Caso Microsoft vs. USA.}

Desde hace muchos años Microsoft tiene un cuasi monopolio sobre los sistemas operativos de los ordenadores, más aún si nos remontamos a la época anterior al auge de Apple, en la cual tenía un poder casi absoluto del mercado. Gracias a su cuota de mercado, Microsoft quiso consolidar otros productos como Internet Explorer utilizando prácticas abusivas contra otras empresas que también incursionaron en el mercado de navegadores web. Tomando en cuenta que el sistema operativo Windows puede ser considerado como una facilidad esencial para la utilización de los ordenadores y la instalación de aplicaciones web, Microsoft pudo utilizarlo para obstaculizar el desarrollo de los productos de sus competidores.

En 1998, el gobierno de Estados Unidos acusó a Microsoft de abusar de su posición en el mercado de navegadores web por presionar de forma anticompetitiva a fabricantes de equipos, proveedores de acceso a Internet, proveedores de contenidos en Internet, desarrolladores de software para que saboteen la distribución de navegadores web de la competencia en favor de Internet Explorer. Asimismo, la acusación planteó que Microsoft había alterado o manipulado su interfaz de programación de aplicaciones o application programming interfaces para favorecer a Internet Explorer por sobre navegadores de otros fabricantes. Microsoft buscaba convertir a Internet Explorer en el principal referente de los navegadores web al generar restricciones en contra de otros navegadores a nivel de distribución del producto y de compatibilidad con el sistema operativo Windows. 
La sentencia de la Corte de Apelaciones condena a Microsoft por dar trato discriminatorio a los fabricantes de ordenadores en función del apoyo prestado por éstos a Netscape Navigator, de tal forma que los fabricantes que marginaban a Navigator, recibían productos de Microsoft de forma gratuita o mayor acceso al código fuente de Windows, mientras que los fabricantes que apoyaban la distribución de Navigator eran penalizados a través de mayores precios o incluso la amenaza de retirada de las licencias de Windows, o bajo la negativa a reconfigurar la secuencia de arranque de Windows (Cuervo, 2003).

Por otro lado, se sanciona a Microsoft por utilizar prácticas ilícitas para intentar frenar la distribución de un middleware ${ }^{22}$ denominado Java Virtual Machine. ${ }^{23}$ Estas prácticas consistían básicamente en penalizar a fabricantes de equipos como por ejemplo IBM, que apoyó a Sun en el desarrollo de Java, y proveedores de aplicaciones que apoyaran la distribución de Java con licencias de Windows más caras o restricciones discriminatorias en el acceso al código fuente de Windows.

En el 2001, el Departamento de Justicia llegó a un acuerdo con Microsoft ${ }^{24}$ para resolver el caso. El acuerdo propuesto requería que Microsoft compartiera su interfaz de programación de aplicaciones con otras empresas y designara un grupo de personas que tuvieran pleno acceso a los sistemas, registros y códigos fuentes de Microsoft durante cinco años para asegurar se cumpliera con los términos del acuerdo (Cuervo, 2003, pág. 223).

Stiglitz (Stiglitz, 2008, pág. 1711) señala que Microsoft no solo abusó de su posición de dominio a través de sus derechos de propiedad intelectual, sino que también

\footnotetext{
${ }^{22}$ Una aplicación informática, como puede ser un programa de correo electrónico, se comunica con otra aplicación, por ejemplo, un sistema de reservas hoteleras o con una red informática como puede ser Internet, utilizando para ello, un tipo de programas informáticos conocidos como Middleware. Según los demandantes por medio de distintas iniciativas, Microsoft intenta que prácticamente sólo existan Middleware que funcionen utilizando su sistema operativo Windows.

${ }^{23}$ Java Virtual Machine es un middleware que puede ser instalado en diversos sistemas operativos y utilizado con diversos navegadores web (Netscape y Explorer).

${ }^{24} \mathrm{El}$ acuerdo no dio fin al asunto debido a que algunos de los Estados denunciantes no se adhirieron al acuerdo suscrito. Sin embargo, la sentencia final recogió gran parte del acuerdo desarrollado.
} 
ralentizó la innovación impidiendo la creación de nuevos programas compatibles con otros navegadores web. Los desarrolladores de aplicaciones web sabían que si producían un producto tan bueno que pueda atraer la atención de Microsoft, indefectiblemente perderían la batalla de no tener los recursos suficientes.

Un uso inadecuado del sistema de patentes puede afectar la eficiencia de la economía y su capacidad de innovación además de imponer costos. A mi consideración los argumentos en contra y los casos citados reflejan los aspectos a mejorar del sistema actual y en ningún caso justifican el reemplazo del sistema de patentes. Tengo la plena confianza que el sistema tiene la capacidad de evolucionar hasta convertirse en uno de los pilares del crecimiento económico. Por último, cabe indicar que los argumentos anotados se materializan en un sistema de patentes laxo donde los requisitos para acceder a la protección por intermedio de una patente son ínfimos.

\subsection{Defendamos la innovación. Arriba las patentes.}

A saber de la OECD, la innovación es considerada la "piedra angular" del crecimiento económico (OCDE-Foro Consultivo, 2012, pág. 5). El premio nobel Douglas North afirma que el origen del crecimiento actual ha sido gracias a los cambios institucionales y no los tecnológicos, como el nacimiento de las sociedades de responsabilidad limitada, la seguridad jurídica de los contratos, la eliminación del monopolio, la propiedad y por último pero no menos importante el surgimiento del sistema de propiedad intelectual ${ }^{25}$ (Acemoglu, Johnson, \& Robinson, 2005). Al respecto, señala que el fracaso en el desarrollo constante de derechos de propiedad sobre las innovaciones es una de las fuentes principales del lento ritmo del cambio tecnológico antes de la Revolución Industrial (North, 1984). A partir del Estatuto de Monopolios de $1623^{26}$ (Turner, 1972)

\footnotetext{
${ }^{25}$ Después de 1688, la seguridad otorgada por los derechos de propiedad en Inglaterra llevaron a una enorme expansión de las instituciones y mercados que, según North y Weingast, sentó las bases institucionales para la revolución industrial. Después de 1689, los derechos individuales a la propiedad y cumplimiento de contratos eran probablemente más seguros en Gran Bretaña que en cualquier otro lado, y fue en Gran Bretaña, no mucho tiempo después de la Revolución Gloriosa, que comenzó la Revolución Industrial" Traducción libre de: "After 1688, the greater security of property rights in England led to a huge expansion of Financial institutions and markets which, North and Weingast (1989) argue, laid the institutional foundations for the industrial revolution", "Individual rights to property and contract enforcement were probably more secure in Britain after 1689 than anywhere else, and it was in Britain, not very long after the Glorious Revolution, that the Industrial Revolution began".

${ }^{26}$ Cabe señalar que el Estatuto de Monopolios fue la primera legislación moderna sobre patentes. Tuvo sus
} 
se estableció un conjunto sistemático de incentivos para fomentar el cambio tecnológico y elevar el rendimiento privado de las innovaciones, acercándose a la tasa social de rendimiento $^{27}$ (North, 1984).

En este sentido, la razón de ser de las patentes atienden a la necesidad de promover la investigación, el desarrollo tecnológico y la innovación, lo que impulsa la competitividad de las empresas, mediante la transferencia de tecnología que se reproduce en bienestar para los consumidores. La formación de monopolios legales por efecto de la concesión de una patente de invención no limita o restringe la competencia, por el contrario al promover la innovación se permite incorporar al mercado un producto que no existía y se promueve así una competencia más leal al evitar que otros empresarios se aprovechen de la investigación y trabajo ajenos (Rodriguez Spinelli, 2008, pág. 93). Por ejemplo, la lucha constante entre empresas como Samsung y Apple por una porción del mercado de teléfonos móviles (López-Tarruela, 2014), ha desatado un sinnúmero de innovaciones en los teléfonos celulares. Cada edición trae consigo una nueva mejora tecnológica, lo que nos lleva a concluir que el ganador de dicha competencia va a ser siempre el que presente mayores innovaciones en su producto.

Si bien el derecho de propiedad intelectual genera un monopolio, ello a su vez genera incentivos para la innovación creando “océanos azules", los cuales se caracterizan por la creación de nuevos nichos mercados creando oportunidades que no son explotadas en la actualidad, y que generan oportunidades de crecimiento rentable y sostenido a largo plazo. En otras palabras, las patentes fuerzan la generación de ideas que hoy por hoy son desconocidas. Por ejemplo, en el rubro de cámaras fotográficas, empresas como Sony que no podían competir con las cámaras instantáneas de Polaroid tuvieron que innovar la forma de capturar fotografías lanzando al mercado las cámaras digitales, lo que ocasionó la bancarrota de Polaroid a causa de la digitalización de las cámaras.

antecedentes en el Estatuto de Venecia de 1474.

${ }^{27}$ North señala que sería erróneo enfatizar demasiado una ley aislada. En este sentido, es casi imposible determinar si esa fue una causa directa para la imposición de las condiciones para que la Revolución Industrial pueda desplegarse. En definitiva, un incremento en la tasa de progreso tecnológico se deriva del incremento de la capacidad del inventor para apropiarse de la mayor parte de los beneficios creados por su invención. 
Bajo la égida del sistema de patentes, las empresas tienen incentivos para el desarrollo de sus ideas sin temor a ser desplazados por otro agente que se apoye en ingeniería inversa para copiar sin incurrir en los costos de inversión del innovador. A pesar de que el sistema otorga un escudo a las empresas comprometidas con la innovación, ${ }^{28}$ éstas incurren en un enorme riesgo, el cual debe ser recompensado. La retribución debe ser inversamente proporcional a las probabilidades de conseguir un producto exitoso.

Por tales razones, se le otorga al creador un derecho de exclusiva temporal con el fin de fomentar la creación de nuevos conocimientos. En áreas de nuevas tecnologías donde los costos de investigación y desarrollo pueden ser altos y la tasa de éxito relativamente bajo -más aún en el caso de la industria farmacéutica- es necesario un derecho verdaderamente exclusivo a la invención para justificar el gasto de grandes sumas en los costos iniciales invertidos en los proyectos de investigación (Corn, 1991, pág. 79).

Los detractores del sistema de patentes ignoran la realidad de que los innovadores requieren una tasa razonable de rendimiento con el fin de inyectar dinero en la investigación y el desarrollo. En algunos casos se trata de muchos millones, incluso cientos de millones de dólares que deben ser invertidos. Es ingenuo creer que alguien pudiera gastar millones o cientos de millones de dólares sin ningún tipo de ventaja competitiva. Si un free rider pudiera copiar y vender por menos el creador perdería todo. Eso no es un modelo de éxito. Es una receta para el fracaso.

El titular de la patente necesita el derecho de exclusiva para recuperar lo invertido y obtener una ganancia. Si tiene éxito, seguramente seguirá investigando, en beneficio de todos por lo que la privación de este beneficio podría eventualmente reducir los precios pero afectaría gravemente la producción de tecnología e innovación. Al respecto,

\footnotetext{
${ }^{28}$ La innovación también depende de los costos y riesgos, la rentabilidad potencial si la invención es técnica y comercialmente exitosa, y la velocidad y facilidad con la que se produce la imitación competitiva de la innovación.
} 
Otamendi sostiene que "no hay razón alguna para que se imponga al titular de la patente normas que le obliguen a bajar el precio. ¿Por qué no hacerlo también con otros que gocen de ventajas competitivas de otra índole? ¿Por qué no obligar a que, para que este (sic) no pueda cobrar más, comparta sus secretos comerciales con sus competidores? ¿Por qué no hacer que limite su publicidad y así estar en igualdad de condiciones con los que realizan poca o ninguna publicidad? En fin, ¿por qué no quitarles a los que tienen ventajas de cualquier clase para entregárselas a los demás y equiparar a todos? Hagámoslo y terminemos con los beneficios que la innovación nos brinda" en (Otamendi, 2006).

Respecto del costo de exclusión del sistema de patentes, cabe preguntarse qué sistema legal hoy en día no resulta complejo y costoso, si bien es cierto que en derecho real la forma de exclusión más simple es la posesión, hay que advertir una obvia diferencia entre estos dos derechos. Las líneas que limitan el espacio físico no pueden duplicarse en la propiedad intelectual. Aun así, los derechos de uso y disposición están sujetos a diversas formas de regulación que pueden eliminar la mayor parte del valor del activo en cuestión (Epstein, 2008, pág. 486). Es ridículo pensar que únicamente el sistema de patentes es costoso, la regulación en general también acarrea altos costos para el Estado y los particulares, sin embargo es necesaria para un mejor funcionamiento de la economía al compensar las fallas de mercado.

Los críticos del sistema de patentes se darían cuenta de que están equivocados si sólo pudieran abrir los ojos y reconocer la verdad de los hechos históricos. No se puede argumentar que las patentes dificultan la innovación o el avance tecnológico o impiden las oportunidades de negocio. El sector de la tecnología está avanzando a una velocidad inimaginable. Lo que fue hace varios años revolucionario está pasado de moda hoy en día. Ésta es una verdad que todo el mundo tiene que reconocer como objetivamente cierta. Si las patentes fueran un estorbo, la situación sería distinta.

Pese a las críticas al sistema de patentes, hasta el día de hoy no se ha desarrollado un sistema alterno que genere un equilibrio entre los intereses de los privados, la sociedad y el Estado. Asimismo, el sistema de propiedad intelectual es un sistema perfectible que a lo largo de la historia ha venido desarrollando mecanismos para alcanzar un equilibrio 
adecuado entre los intereses mencionados. Estados Unidos recientemente ha establecido mecanismos para contrarrestar algunas fallas. Las sanciones impuestas por la Corte Suprema de los Estados Unidos a los troles de patentes ${ }^{29}$ reducen a la mínima expresión el retraso a la innovación generado por éstos.

Tengo la plena confianza que se implementará los mecanismos necesarios para paliar las desventajas que conlleva el sistema de patentes. Así como se ha establecido mecanismos para contrarrestar las marañas de patentes otorgando licencias obligatorias por segundo uso y estableciendo sanciones para los troles de patentes, también se ha incluido mecanismos para equilibrar los intereses de los privados y la sociedad a partir de las salvaguardas establecidas en los ADPIC desarrolladas en los capítulos siguientes.

\subsection{Sistemas alternativos a los derechos de propiedad intelectual.}

El debate acerca de la idoneidad del sistema de patentes como mecanismo para fomentar la investigación y el desarrollo tecnológico es profuso. Entre una posición y otra existen abismos que pugnan ante las ideas de interés privado y bienestar social. Sin embargo, es evidente que la Propiedad Intelectual ha significado un trampolín para el desarrollo de los grandes cambios industriales de manera que ha generado grandes revoluciones tecnológicas y sociales.

Sin embargo, resulta válido cuestionar si el sistema de patentes es el más adecuado para promover la innovación. En este capítulo se examinan varias alternativas a la concesión de derechos exclusivos, entre las que se incluye la financiación pública de actividades de investigación, políticas fiscales, discriminación de precios, restricciones de monopolios de patentes, financiamiento de la investigación en función de un porcentaje de la venta de productos y premios de incentivo a la innovación.

Los métodos alternativos de promoción de innovación a examinar presentan

\footnotetext{
${ }^{29}$ Alice Corporation PTY vs. CLS Bank International. 573. US. 2014. Disponible en: http://www.supremecourt.gov/opinions/13pdf/13-298_7lh8.pdf Recuperado el 1 de julio del 2014.
} 
ventajas así como costos y limitaciones al igual que los derechos de propiedad intelectual. Por ello, es aconsejable realizar análisis económicos sobre cada una de las características de los sistemas lo que resulta útil para suplir las deficiencias del sistema de propiedad intelectual actual.

\subsubsection{Sistema de premios.}

Los premios de incentivo a la innovación son un antiguo mecanismo que desde hace poco vuelve a tener cabida, ya sea como complemento o como sustituto de los derechos de propiedad intelectual. El sistema implica dar un premio a quien se le ocurre una innovación, o al menos aquellas innovaciones que cumplan con objetivos predeterminados. Por ejemplo, la persona que encuentra una cura o una vacuna para el VIH/SIDA o la malaria obtendría un premio considerable. Si una persona viene con un medicamento con menores efectos secundarios que los fármacos existentes pero igual de efectivo obtendría un pequeño premio por reducir los efectos secundarios. En otras palabras, el tamaño del premio se calibra por la magnitud de la contribución.

Esta idea no es nueva, desde hace siglos la Royal Scottish Society of Arts (RSSA) ha estado abogando por el uso de premios para incentivar el desarrollo de las tecnologías necesarias para la sociedad. Por ejemplo, anteriormente las chimeneas eran limpiadas por niños pequeños de la calle a cambio de unas monedas. Debido a que ello afectaba la salud de los niños, la RSSA ofreció un premio a cualquier persona que invente una forma mecánica para la limpieza de chimeneas. De esta manera, George Smart obtuvo el premio al inventar la primera herramienta en la historia utilizada para limpiar chimeneas.

Un sistema de patentes también podría haber motivado el desarrollo de un dispositivo mecánico, con lo cual no hubiera podido resolverse el problema de salud. De alguna forma, el titular de la patente habría encontrado la manera de maximizar el retorno de su innovación mediante el cobro de una renta alta por el uso de su invento. Ello podría haber significado que sólo las familias con un nivel socioeconómico alto podían permitirse el lujo de usar dicho dispositivo, y las vidas de los niños hubieran seguido en riesgo. 
El actual sistema de patentes es, por supuesto, similar a un sistema de premios, pero de algún modo es ineficiente, ya que el "premio" es una concesión de poder de monopolio, y con dicho poder existen incentivos para restringir el uso del conocimiento. Una de las características de un sistema de innovación deseable es que las ideas e innovaciones, una vez desarrolladas, sean ampliamente utilizadas y difundidas. Lo ideal es utilizar el mercado competitivo para asegurar una difusión eficaz del conocimiento; dando una licencia a un gran número de personas que utilizan la fuerza de la competencia para bajar el precio y aumentar el uso del conocimiento (Spulber, 2014).

En la actualidad las compañías farmacéuticas tienen incentivos insuficientes para desarrollar medicamentos para las enfermedades del tercer mundo como el Ébola, enfermedad de Chagas o el paludismo, simplemente porque no existe un mercado llamativo. Una de las ideas ampliamente discutidas para hacer frente a este problema es un fondo garantizado de compra de los medicamentos, donde el Banco Mundial garantice uno o dos mil millones de dólares para alguien que descubra (y patente) una vacuna o una cura para el SIDA o la malaria o alguna otra enfermedad que afecte a los países en desarrollo para la compra de la droga. La garantía de compra por dos billones de dólares o más del medicamento actuaría como una garantía de mercado lo suficientemente grande como para motivar la investigación. Estos fondos garantizados, sin embargo, conservan la ineficiencia del sistema de patentes de monopolio al permitir cobrar precios de monopolio. Por supuesto, las personas de escasos recursos pueden obtener el medicamento a través del fondo de compra garantizada. Pero los fondos son limitados. Cuando los fondos se agotan, un gobierno que quiere proporcionar a sus ciudadanos, por ejemplo, la medicina para la enfermedad de Chagas que se ha incentivado a través del fondo de compra garantizado tendrá que pagar el precio de monopolio. El dinero gastado para comprar este fármaco en el precio de monopolio es dinero que no se puede gastar en otras necesidades de salud del país. Sin embargo, es más eficiente usar el dinero del fondo de compra garantizada para ofrecer un "premio" o para comprar la patente, y que esté disponible libremente (o cualquiera que esté dispuesto a pagar una cuota de licencia limitada) en (Stiglitz, 2008). 


\subsubsection{Comparación de sistemas.}

Es aconsejable elaborar análisis económicos de los costos y beneficios y de la idoneidad de distintos mecanismos para lograr objetivos de innovación adecuados a un contexto específico. Asimismo, la utilización combinada de diversos mecanismos puede ser útil para superar las carencias importantes de un mecanismo en particular (OMPI, 2014).

Stiglitz ha realizado una comparación entre los principales sistemas de innovación: derechos de propiedad intelectual, el sistema de precios y programas de investigación por el gobierno, la cual se encuentra desarrollada en la Tabla 1.

Tabla 1. Comparación de sistemas de innovación.

\begin{tabular}{|c|c|c|c|}
\hline \multicolumn{5}{|c|}{ Atributo } & \multicolumn{2}{|c|}{ Patentes } & \multicolumn{2}{c|}{ Premios } & \multicolumn{1}{c|}{$\begin{array}{c}\text { Promoción } \\
\text { gubernamental }\end{array}$} \\
\hline Selección & $\begin{array}{c}\text { Descentralizado, } \\
\text { autoselección. Falta } \\
\text { de coordinación }\end{array}$ & $\begin{array}{c}\text { Descentralizado, } \\
\text { autoselección. Falta } \\
\text { de coordinación. }\end{array}$ & $\begin{array}{c}\text { Burocrático. Mayor } \\
\text { coordinación. }\end{array}$ \\
\hline $\begin{array}{c}\text { Financiamiento } \\
\text { Alta distorsión y } \\
\text { falta de equidad. }\end{array}$ & $\begin{array}{c}\text { Menos distorsión. } \\
\text { Más equitativo. }\end{array}$ & Eficiente. \\
\hline $\begin{array}{c}\text { Diseminación del } \\
\text { conocimiento }\end{array}$ & $\begin{array}{c}\text { Limitado- } \\
\text { monopolio. }\end{array}$ & $\begin{array}{c}\text { Alto - mercado } \\
\text { competitivo. }\end{array}$ & Alto. \\
\hline Riesgo & Alto riesgo. & Bajo Riesgo. & Sin riesgos. \\
\hline $\begin{array}{c}\text { Incentivos de } \\
\text { innovación }\end{array}$ & $\begin{array}{c}\text { Alto, alta } \\
\text { distorsión. }\end{array}$ & $\begin{array}{c}\text { Requiere objetivos } \\
\text { definidos. }\end{array}$ & $\begin{array}{c}\text { Sin incentivos } \\
\text { incentantivos no } \\
\text { monetarios) }\end{array}$ \\
\hline $\begin{array}{c}\text { Costos de } \\
\text { transacción }\end{array}$ & Alto. & Bajo. & Bajo. \\
\hline
\end{tabular}

Fuente: STIGLITZ, Joseph. Economic foundations of intellectual property rights.

Una de las desventajas del sistema de patentes y el de premios es la falta de coordinación. Desde un punto de vista social, existe el riesgo de duplicación excesiva. ${ }^{30}$ La falta de coordinación aumenta el costo de la investigación. Uno de los riesgos que

\footnotetext{
${ }^{30}$ Considerar que el riesgo de duplicación si puede ser óptimo desde un punto de vista social según Stiglitz, pero no una duplicación altamente excesiva.
} 
enfrenta cada investigador es que no sabe cuántas otras personas se dedican a la misma investigación. Eso aumenta el riesgo de que el desarrollo realizado sea en vano si otra persona obtiene la patente previamente. Quienes se dedican a la investigación demandan mayores ingresos debido al riesgo de perder la carrera por la patente. Por otra parte, los fondos de investigación de gobierno son más eficientes en ese aspecto.

En lo que respecta al financiamiento, el sistema de patentes es el menos ventajoso de tres sistemas. La forma en que obtiene sus recursos a costa de las personas de menos recursos (que adquieren fármacos de primera necesidad) para financiar farmacéuticos de segunda necesidad tal como productos para la calvicie, disfunción eréctil entre otros genera distorsiones sociales y económicas.

Sobre la difusión del conocimiento y su uso eficiente, la investigación financiada por el gobierno es el mejor opción ya que el conocimiento es de libre disposición una vez se obtiene; el sistema de premios es la segunda mejor opción por un corto margen con la investigación financiada por el gobierno ya que el conocimiento puede ser de libre disposición o cobrar una tarifa mínima de licencia. El sistema de patentes tiene un monopolio sobre el conocimiento lo que implica altos precios y un uso sumamente restringido por lo que se considera este sistema como la última opción en este extremo. En resumen, en el marco del premio y los sistemas de investigación financiados por el gobierno, el conocimiento, una vez adquirido, se utiliza de manera más eficiente.

En términos de riesgo, el sistema de patentes es de lejos el que implica mayores riesgos debido a los innumerables litigios que conlleva. La investigación financiada por el gobierno es la que lleva menos riesgos porque la investigación se paga desde el inicio ( $\sin$ importar los resultados). En ese sentido, un investigador recibe dinero y otros recursos para la investigación desde el inicio mientras que en el sistema de premios patentes los investigadores ganan únicamente si su investigación se realiza correctamente y con éxito antes de que sus competidores.

En áreas donde existen necesidades bien definidas (tal como el desarrollo de una 
vacuna contra la malaria), tanto el sistema de premios como el sistema de patentes pueden proporcionar incentivos igual de ventajosos para que se lleve a cabo investigación. Ambos tienen una ventaja sobre la investigación financiada por el gobierno ya que nadie ni ningún burócrata del gobierno elige quién debe realizar la investigación. Aquellos que piensan que tienen las mejores perspectivas de éxito (y son capaces de financiar la investigación y dispuestos a asumir el riesgo) pueden llevar a cabo el proyecto. Sin embargo, la ventaja del sistema de premios es la amplia difusión de los beneficios de la innovación, es decir una vez obtenido el premio la vacuna puede ser utilizada por cualquiera a diferencia del sistema de patentes que a través del monopolio restringe su uso.

A pesar que el sistema de premios tiene atributos más ventajosos frente al sistema de patentes, tiene una importante limitación: no existe un método para definir el área que necesite una mayor investigación, en consecuencia, existe un alto riesgo que los premios se otorguen a investigaciones con baja prioridad para la sociedad lo que puede implicar mayores costos que el sistema de patentes, el cual utiliza un sistema de autoselección para definir las áreas de investigación de mayor necesidad.

La investigación puede ser clasificada por diversos criterios, según el propósito o finalidad perseguida en la que estaríamos frente a una investigación básica o aplicada. Se puede afirmar que la investigación denominada básica sería aquella cuyo fin fundamental es la generación de conocimiento teórico y la investigación aplicada pretende desarrollar soluciones a problemas prácticos (Gonzales).

El debate de selección gira en torno al financiamiento de la investigación aplicada la cual tiene progresos tangibles para la sociedad. Sin embargo, el núcleo de la innovación corresponde a la investigación pura o básica, la cual actualmente es financiada por el gobierno y universidades. Dicho tipo de investigación es bastante criticada debido a que implica la utilización de grandes recursos sin tener una aplicación inmediata.

En resumen, en palabras de la OMPI, el sistema de patentes presenta las siguientes 
ventajas: unos procesos decisorios descentralizados; un sistema de recompensa que puede movilizar con rapidez recursos que proceden directamente de los usuarios que se benefician de la invención, y la divulgación de las invenciones. Entre los costos del sistema de patentes, cabe señalar el alto precio de los productos, obstáculos jurídicos a la utilización de las invenciones como base de innovaciones subsiguientes y los considerables costos que supone evaluar y hacer valer las patentes. El sistema de patentes presenta limitaciones en determinadas actividades de $\mathrm{I}+\mathrm{D}$, actividades de $\mathrm{I}+\mathrm{D}$ previas a la comercialización, resultados de la investigación que no se pueden monopolizar ni rentabilizar con éxito y, en particular, la ejecución de proyectos de desarrollo arriesgados, por mencionar algunas de las limitaciones más conocidas del sistema de patentes (OMPI, 2014).

\subsubsection{Discriminación de precios.}

La modalidad de discriminación de precios se enmarca dentro del sistema de patentes, sin embargo dicha modalidad elimina el argumento principal que los monopolios generados por el sistema de patentes conducen a precios inaccesibles para algunos sectores de la sociedad.

Según el profesor Kevin Outterson (Outterson, Pharmaceutical Arbitrage: Balancing Access and Innovation in International Prescription Drug Markets, 2004), la mayoría de los economistas se encuentran de acuerdo que de acuerdo en que, en el país de las maravillas, las empresas farmacéuticas evitarían el riesgo de las licencias obligatorias fijando precios de sus productos cerca de su costo marginal para que las personas de escasos recursos pudieran acceder a estos medicamentos. Suponiendo que existen diversas formas de evitar que los medicamentos de precios bajos sean exportados a los países desarrollados, las empresas farmacéuticas en teoría, podrían discriminar los precios de sus productos sobre la base del Producto Bruto Interno per cápita. De este modo obtendrían pequeños ingresos por el gran volumen de ventas en los países más pobres, compensados por las ventas a precios más altos en los países de ingresos medios y altos.

La discriminación de precios es una práctica comercial que implica vender 
unidades de un mismo bien o servicio a diferentes precios. Por ejemplo, ello puede verificarse en los pagos de las mensualidades de las universidades de nuestro país, las cuales varían de acuerdo a la escala económica de los padres del alumno. Los de mayor capacidad de pago subsidian la mensualidad de las personas con menos recursos. La escala de pagos en las universidades es un modelo que se podría seguir para el cobro de medicamentos a los usuarios.

Esta modalidad es una estrategia que permite fácilmente incrementar el nivel de beneficios de la empresa que la emplea perjudicando a los consumidores. Por ejemplo, la venta de pasajes aéreos tiene una tarifa variable, las empresas cobran una tarifa más alta a los usuarios que adquieren su pasaje en una fecha cercana al vuelo aprovechándose de la urgencia del usuario. Sin embargo, en el mercado farmacéutico sucede lo contrario, la discriminación de precios sirve para vender farmacéuticos a los países menos desarrollados o personas con escasos recursos a un precio menor del que se venden en otros países o a personas con altos ingresos.

Para apoyar la diferenciación de precios entre países se ha propuesto el uso de precios de Ramsey. Los precios Ramsey (Ramsey, 1927) es un conjunto de precios diferenciados que generan un mayor bienestar social, garantizando un nivel de beneficios especificados para el productor. La solución de los precios Ramsey es que los precios deberían diferir a través de los diferentes segmentos del mercado en relación inversa a sus elasticidades de la demanda. El ideal para los usuarios sería la compra de los productos a un precio cerca del costo marginal, sin embargo la comercialización no cubriría los costes de I+D. Los precios Ramsey brindan una solución sin renunciar a este ideal: los usuarios más sensibles a los precios deben pagar un pequeño margen adicional sobre los costos marginales a diferencia de los usuarios que no son sensibles, los cuales pagarán un margen mayor sobre los costos marginales (Danzon \& Towse, A Differential Pricing for Pharmaceuticals: Reconciling Access, R\&D and Patents, 2003, pág. 23).

Los precios Ramsey se aplican usualmente en la regulación de precios de los servicios públicos y pueden adaptarse a otras industrias como la provisión de medicamentos. La fijación de precios Ramsey asume que el valor social de un dólar 
adicional de consumo de un individuo es el mismo en todos los mercados. En las economías occidentales esto puede no ser descabellado, pero cuando se encuentran economías de países desarrollados y en vías de serlo, igualar el valor de un dólar en Estados Unidos con el valor del mismo dólar en Perú es todo un reto debido a que el valor adquisitivo de dicho dólar es distinto. Los precios Ramsey no solo funcionan entre países, sino también pueden funcionar dentro un país. Por ejemplo, en la Figura 1 se muestran diez segmentos económicos, en los cuales podrían aplicarse precios Ramsey en los pagos de los farmacéuticos (Barros \& Martinez-Giralt, 2008) de acuerdo a la capacidad de pago de cada segmento. Si consideramos que lo máximo que pueden pagar por medicamentos es el 10\% de su renta anual, el Decil 1 únicamente podrá pagar 186 soles a diferencia del Decil 10 que tiene la capacidad de pagar 3527 soles.

Figura 1. Ingreso promedio anual per cápita en Perú. Año 2015.

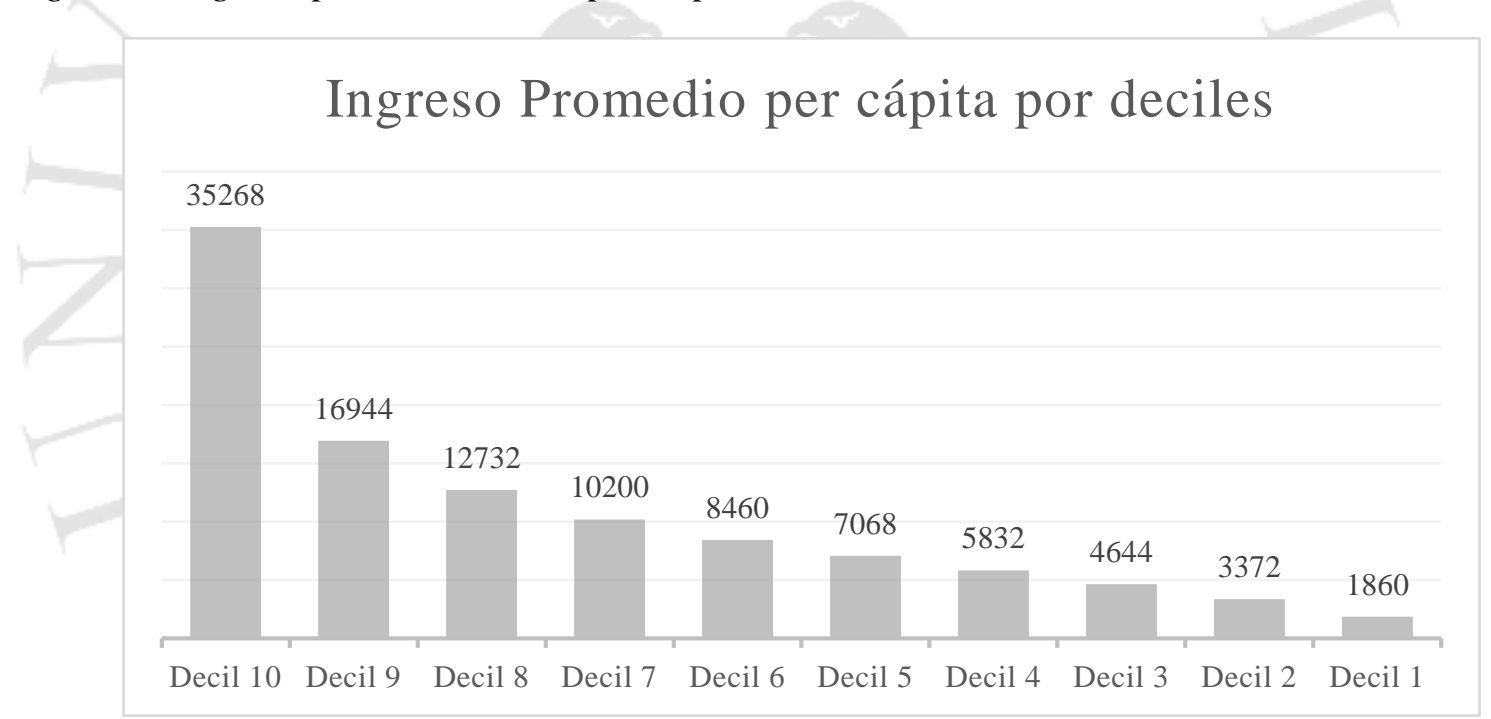

Elaboración Propia. Fuente: Datos obtenidos de Evaluación de la Pobreza Monetaria 2009-2015. INEI. Ingreso en soles constantes base $=2015$ a precios de Lima Metropolitana.

Si elaboramos un modelo de precios Ramsey con un universo de quinientos cincuenta personas que representen a los sectores económicos del Perú (Ver Tabla 2) y el coste marginal de los farmacéuticos sea casi igual a cero, la empresa podrá obtener rentas por el total de 359784 unidades monetarias anuales ya que obtiene la renta de todos los usuarios de acuerdo a su capacidad de pago. Sin embargo, si se fija un precio fijo por los medicamentos, el titular de la patente tendrá que fijar el precio correspondiente a la capacidad de pago del Decil 5 obteniendo rentas por 42408 unidades 
monetarias anuales.

Tabla 2. Rentas obtenidas por precios Ramsey.

\begin{tabular}{|c|c|c|c|}
\hline Decil & \multicolumn{1}{c}{$\begin{array}{c}\text { Número de } \\
\text { personas }\end{array}$} & \multicolumn{1}{c|}{$\begin{array}{c}\text { Capacidad } \\
\text { de pago }\end{array}$} & \multicolumn{1}{c|}{$\begin{array}{c}\text { Rentas } \\
\text { obtenidas }\end{array}$} \\
\hline Decil 10 & 10 & 3527 & 35268 \\
\hline Decil 9 & 20 & 1694 & 33888 \\
\hline Decil 8 & 30 & 1273 & 38196 \\
\hline Decil 7 & 40 & 1020 & 40800 \\
\hline Decil 6 & 50 & 846 & 42300 \\
\hline Decil 5 & $\mathbf{6 0}$ & $\mathbf{7 0 7}$ & $\mathbf{4 2 4 0 8}$ \\
\hline Decil 4 & 70 & 583 & 40824 \\
\hline Decil 3 & 80 & 464 & 37152 \\
\hline Decil 2 & 90 & 337 & 30348 \\
\hline Decil 1 & 100 & 186 & 18600 \\
\hline Total & 550 & - & $\mathbf{3 5 9 7 8 4}$ \\
\hline
\end{tabular}

Elaboración Propia. Fuente: Datos obtenidos de Evaluación de la Pobreza Monetaria 2009-2015. INEI. Ingreso en soles constantes base $=2015$ a precios de Lima Metropolitana.

La discriminación de precios permite reducir la pérdida de demanda insatisfecha, es decir, las pérdidas que se producen cuando los consumidores que comprarían los productos no pueden permitirse el lujo por tener un precio mayor a su capacidad de pago. Suponiendo que la compañía espera recuperar la inversión de I+D y la mayor parte de sus beneficios en países desarrollados, la venta de los mismos productos a un gran número de personas pobres a precios muy bajos (pero aún por encima del costo marginal de producción) genera beneficios al menos igual de ventajosos que los logrados por las compañías de genéricos (Outterson \& Aaron, Market-Based Licenses for HPV Vaccines in Developing Countries, 2008) sin considerar la venta en países desarrollados. Según Scherer, el bienestar global mejoraría si la innovación farmacéutica fuera aprovechada por los países más pobres (Scherer, 2004).

Así que ¿por qué las empresas farmacéuticas evitan la adopción de una estrategia de discriminación de precios (junto con acuerdos vinculantes para limitar las exportaciones paralelas)? Según Patricia Danzón y Adrian Towse (Danzon \& Towse, 
2005) las farmacéuticas tienen bastante cautela al fijar un precio bajo en otros países debido a que los reguladores de países de la OCDE con mecanismos de control de precios pueden tomar dicho precio como "precio de referencia"31 (Madrid, 1998). Por ejemplo, si las farmacéuticas comercializan un antirretroviral al precio de un centavo la píldora dentro de territorio africano, el regulador de Canadá, podría resistirse a permitir que se comercialice a cien o doscientos dólares la misma píldora en territorio canadiense, incluso si la Junta de Revisión de Precios de Medicamentos -el regulador de precios de Canadáentiende que las empresas deben recuperar la inversión de millones de dólares en I + D. En el documental "Fire in the Blood" (Mohan, 2013), Joseph Stiglitz señala que si los países del primer mundo vieran que su población está pagando 10 mil dólares al año por el tratamiento de VIH y en otros países se cubre el mismo tratamiento por 150 dólares al año, se preguntarían porque ellos tienen que pagar tanto, más aún si los beneficios del desarrollo de I+D es global y no únicamente para los que pagan más. Stiglitz señala que lo que más temen las farmacéuticas es el "efecto dominó" que podría ocasionar un país del primer mundo al replicar los precios bajos de los medicamentos dados a los países menos desarrollados. En ese sentido, Danzón y Towse proponen un sistema de descuentos secretos que podrían promover una mayor discriminación de precios, limitando la capacidad de los reguladores extranjeros para descubrir los precios efectivamente cobrados a los distribuidores en los países pobres para su uso como precios de referencia de los países ricos (Danzon \& Towse, 2005).

Para que la discriminación de precios sea válida hay que conseguir una segregación entre mercados de manera que se impida reexportar a los países con precios más altos, lo cual es posible: tanto Estados Unidos como la Unión Europea restringen la importación de productos patentados incluso cuando la primera venta del producto al exterior la realiza el propietario de la patente, su licenciatario o alguna subsidiaria. En este sentido, para que la discriminación de precios funcione es necesario prohibir las importaciones paralelas entre países.

\footnotetext{
${ }^{31}$ Precios fijados por comparación con los precios de otros medicamentos. Los precios de referencia interna similares usan medicamentos similares en el mercado nacional. La fijación externa de precios de referencia usa medicamentos que son iguales o similares a los vendidos en otros países.
} 


\section{4. ¿Resulta necesario cambiar el modelo actual de innovación?}

El sistema de patentes presenta las siguientes ventajas: unos procesos decisorios descentralizados; un sistema de recompensa que puede movilizar con rapidez recursos que proceden directamente de los usuarios que se benefician de la invención, y la divulgación de las invenciones. Entre los costos del sistema de patentes, cabe señalar el alto precio de los productos, obstáculos jurídicos a la utilización de las invenciones como base de innovaciones subsiguientes y los considerables costos legales que supone evaluar y hacer valer las patentes (OMPI, 2014).

A pesar de los costos de los derechos de propiedad intelectual, es indudable que el sistema de patentes ha demostrado una incidencia de amplio espectro en la economía y en la sociedad como principal fuente de promoción de innovación en el mercado de los productos y servicios. Es por ello, que el sistema de patentes a mi consideración es el más adecuado para incentivar el desarrollo de nuevas tecnologías y productos. Resulta natural que dicho sistema evolucione a lo largo del tiempo corrigiendo los errores que pueda presentar.

En el siguiente capítulo estudiaremos la historia de la evolución del sistema de propiedad intelectual y los dispositivos que fueron incorporados para lograr un balance adecuado entre el Estado, los innovadores y la sociedad. 


\section{CAPÍTULO III: EL EQUILIBRIO ES LA CLAVE. SALVAGUARDAS EN LOS ADPIC.}

El conflicto analizado entre la innovación y competencia en el campo de la política económica y social para el desarrollo del país no es una discusión exclusiva del derecho de la competencia y la propiedad intelectual. Sino también, le concierne fundamentalmente a la teoría de la regulación.

Uno de los conflictos más básicos e importantes que subyacen a la regulación y política pública del estado es el equilibrio perfecto de los intereses de la sociedad. En la búsqueda del equilibrio óptimo nace la necesidad de regular el funcionamiento económico, donde regular se interpreta como estabilizar y distribuir eficientemente (Pasco-Font, 2008). La eficiencia no solo debe ser económica, sino también social, para ello es necesario crear condiciones para que se establezca el ordenamiento competitivo a través de una política activa que deriva necesariamente por el desarrollo claro de los derechos de propiedad intelectual y por la vigencia de la competencia en los mercados.

Es por ello, que el sistema de propiedad intelectual, específicamente el sistema de patentes, ha sido objeto de numerosas reformas que permiten en determinadas circunstancias contrarrestar situaciones de desequilibrio. Sin embargo, si estas herramientas no son utilizadas adecuadamente pueden generar un efecto contrario perjudicando la innovación.

Las reformas mencionadas en el capítulo anterior cambiaron radicalmente el marco legal para la producción, comercialización y acceso a medicamentos en los países en desarrollo, a pesar de que el acuerdo sobre los ADPIC da cierto margen de maniobra a algunos miembros con el fin de que adopten medidas que les permitan mitigar el derecho del monopolio conferido por la patente y promover la competencia. Las medidas en cuestión, que básicamente les permiten aumentar el acceso a medicamentos incluyen 
principalmente la importación paralela, ${ }^{32}$ la excepción bolar ${ }^{33}$ y la licencia obligatoria. ${ }^{34}$ La tabla siguiente presenta las principales salvaguardas establecidas en ADPIC en relación a los derechos de propiedad intelectual:

Tabla 3. Disposiciones del Acuerdo sobre los ADPIC.

\begin{tabular}{|c|c|c|}
\hline Disposiciones & $\begin{array}{c}\text { Artículo del Acuerdo sobre } \\
\text { los ADPIC }\end{array}$ & Definición \\
\hline $\begin{array}{llrr} & & \\
\text { Período de } & \text { transición } \\
\text { para } & \text { adaptar } & \text { la } \\
\text { legislación nacional } & \text { al } \\
\text { Acuerdo } & \text { sobre } & \text { los } \\
\text { ADPIC. } & & \end{array}$ & $\begin{array}{l}\text { Art. } 65 . \\
\text { Arreglos Transitorios. } \\
\text { Art. } 66 . \\
\text { Países menos desarrollados. }\end{array}$ & $\begin{array}{l}\text { Desde enero de 1995, los Estados Miembros } \\
\text { de la OMC han tenido los siguientes plazos } \\
\text { para modificar sus legislaciones nacionales: } \\
\text { 1. Países desarrollados: } 1 \text { año (hasta enero de } \\
\text { 1996). } \\
\text { 2. Países en desarrollo: } 5 \text { años (hasta enero } \\
\text { de 2000). } \\
\text { 3. Países menos desarrollados: } 11 \text { años } \\
\text { (hasta enero del 2006). }\end{array}$ \\
\hline
\end{tabular}

3. Países menos desarrollados: 11 años
(hasta enero del 2006).

\footnotetext{
${ }^{32}$ El término "importación paralela" se refiere a la importación, sin la autorización del propietario de la patente, de un producto patentado que es comercializado en el extranjero por el titular de la patente o por una persona autorizada. Las importaciones paralelas son una excepción al derecho, normalmente exclusivo del propietario de la patente, para poder importar. Dichas importaciones están autorizadas según el principio del agotamiento internacional de los derechos, de acuerdo al cual el propietario de la patente extingue los derechos de su patente colocando su producto en el mercado y, por lo tanto, ya no puede controlar el movimiento de los bienes comercializados, pudiendo un tercero adquirir el medicamento en otro país en el que se comercialice con un precio más bajo y colocarlo en el mercado nacional. El Artículo 6 del Acuerdo sobre los ADPIC permite a los estados Miembros de la OMC autorizar importaciones paralelas, tal como lo confirma la Declaración relativa al Acuerdo sobre los ADPIC y la Salud Pública adoptada en Doha. El párrafo 5(d) de la Declaración establece que "el efecto de las disposiciones en el Acuerdo sobre los ADPIC que son relevantes a la extinción de los derechos de propiedad intelectual es dejar a cada miembro libre para establecer su propio régimen para dicha extinción sin cuestionamiento" (Boulet, 2001).

${ }^{33}$ La excepción por Explotación anticipada o Excepción "Bolar", es otra medida permitida bajo los términos del Acuerdo sobre los ADPIC. Su objetivo es precisamente acelerar la comercialización de medicamentos genéricos al final del período de la patente, a fin de estimular la competencia de precios. Cuando se incluye en la ley de patentes, dicha excepción permite a los competidores genéricos realizar todas las acciones necesarias para obtener el registro de sus productos por parte de las autoridades farmacéuticas, mientras la patente aún está vigente. Estas acciones incluyen la fabricación limitada del producto patentado, a fin de llevar a cabo las pruebas requeridas por las autoridades de salud. Los fabricantes genéricos pueden entonces empezar a producir y comercializar sus productos en la fecha en que la patente relevante expire, sin necesidad de esperar el registro farmacéutico, que puede suponer de 2 a 3 años en algunos países (Boulet, 2001).

${ }^{34}$ El instituto ya se hacía presente en el Convenio de París para la Protección de la Propiedad Industrial en sus revisiones de 1925 (La Haya) y 1931 (Londres). Desde ese marco, las licencias obligatorias pasaron a incorporarse en el derecho interno de muchos Estados.
} 


\begin{tabular}{|c|c|c|}
\hline $\begin{array}{l}\text { Período de transición } \\
\text { para reconocer las } \\
\text { patentes en sectores } \\
\text { tecnológicos no } \\
\text { protegidos antes del } \\
\text { Acuerdo de los ADPIC } \\
\text { (por ejemplo, protección } \\
\text { de patentes en el sector } \\
\text { químico de varios } \\
\text { países). }\end{array}$ & Art. 65.4. & $\begin{array}{l}\text { Los países en desarrollo tienen un período } \\
\text { adicional de } 5 \text { años (hasta 2005) para } \\
\text { reconocer patentes en los sectores } \\
\text { anteriormente } \\
\text { Nota: la Declaración Ministerial de Doha } \\
\text { definió en el párrafo } 7 \text {, que los países menos } \\
\text { desarrollados pueden extender ese período } \\
\text { de transición hasta el } 01 / 01 / 2016 \text { para los } \\
\text { productos y procesos farmacéuticos. }\end{array}$ \\
\hline $\begin{array}{l}\text { Importaciones paralelas } \\
\text { o agotamiento de los } \\
\text { derechos a nivel regional } \\
\text { y/o internacional. }\end{array}$ & $\begin{array}{l}\text { Art. } 6 . \\
\text { Agotamiento de los derechos. }\end{array}$ & $\begin{array}{l}\text { La importación paralela involucra la } \\
\text { importación y reventa en un país, sin el } \\
\text { consentimiento del titular de la patente, de } \\
\text { un producto patentado colocado en el } \\
\text { mercado del país exportador por el titular de } \\
\text { la patente o de otra manera legítima. }\end{array}$ \\
\hline $\begin{array}{l}\text { Excepción Bolar } \\
\text { (Explotación temprana). }\end{array}$ & $\begin{array}{l}\text { Art. } 30 \text {. } \\
\text { Excepciones a los derechos } \\
\text { otorgados. }\end{array}$ & $\begin{array}{l}\text { Esta excepción permite que una empresa } \\
\text { realice todos los procedimientos y pruebas } \\
\text { necesarias para obtener la aprobación en el } \\
\text { mercado para un producto genérico antes } \\
\text { que la patente original expire. }\end{array}$ \\
\hline Licencia Obligatoria. & $\begin{array}{l}\text { Art. } 31 . \\
\text { Otro uso sin autorización del } \\
\text { titular de la patente. }\end{array}$ & $\begin{array}{l}\text { Permite la explotación de un objeto } \\
\text { patentado, sin el consentimiento del titular } \\
\text { de la patente, mediante autorización del } \\
\text { gobierno pero con remuneración. }\end{array}$ \\
\hline
\end{tabular}

Fuente: BERMUDEZ, Jorge. La propiedad Intelectual en el contexto del acuerdo de la OMC sobre los ADPIC: desafíos para la salud pública.

Una ley de propiedad industrial sensible a los intereses en salud debe incluir todas las flexibilidades y salvaguardias contempladas en el Acuerdo sobre los ADPIC, como por ejemplo, el agotamiento internacional de los derechos (importaciones paralelas), la excepción bolar y todas las demás condiciones que permiten la emisión de una licencia obligatoria. También es importante que los países utilicen todo el período de transición para realizar las reformas a su legislación. La incorporación de las flexibilidades y salvaguardias no es obligatoria, pero sí esencial, para minimizar el impacto negativo de la protección de patentes en las políticas de salud (Bermudez, 2006). Una legislación sensible a la salud pública debe posibilitar que los gobiernos actúen eficientemente en emergencias nacionales y en situaciones de interés público.

La flexibilidad de la importación paralela representa una importante herramienta 
competitiva para promover el acceso a medicamentos a menor costo permitiendo aprovechar las diferencias de precios de cada país. La importación paralela no infringe los ADPIC ya que el derecho de patente del titular se agotó en el país donde el producto fue originalmente comercializado a precio más bajo (Bermudez, 2006).

Asimismo, gracias a la excepción bolar aquellos terceros que deseen producir, por ejemplo, fármacos genéricos, podrán practicar las pruebas de bio-equivalencia para la aprobación de comercialización antes de la expiración de la patente. Con ello, el ingreso de medicamentos competidores al mercado puede ser mucho más expedito aumentando explosivamente la oferta, con la consiguiente reducción en los precios de medicamentos (Franjola, 2009).

\subsection{Sistema de Propiedad Intelectual: Marco legal.}

El sistema de Propiedad Industrial se encuentra agrupado en distintos instrumentos jurídicos con diferentes niveles normativos. Desde tratados internacionales hasta normas regionales y nacionales que dotan de contenido a los primeros, que se aplican para resolver los conflictos que se presenten en cada elemento de la propiedad intelectual.

La norma de mayor jerarquía para el Perú es la Constitución Peruana, que en su artículo $2^{\circ}$ inciso 8), Capítulo I establece: “Toda persona tiene derecho a la libertad de creación intelectual, artística, técnica y científica, así como a la propiedad sobre dichas creaciones y a su producto"; en este artículo vemos que los derechos de propiedad intelectual son derechos fundamentales de la persona con rango constitucional.

Como hemos revisado en el primer capítulo, el primer tratado internacional sobre la materia es la Convención de París de 1883 que da lugar a los primeros pasos de la globalización de la protección de la propiedad industrial. Dicho tratado establece los pilares de todos los sistemas de propiedad intelectual y reglas comunes de las 174 partes contratantes o países miembros. 
En el mismo nivel de la Convención de París se encuentra el Acuerdo sobre los Aspectos de los Derechos de Propiedad Intelectual relacionados con el Comercio (ADPIC), el cual supera en términos cualitativos a los tratados adoptados anteriormente y ahonda en todos los aspectos del sistema de propiedad intelectual. Dicho acuerdo es, sin lugar a dudas, el principal instrumento internacional para la protección de la propiedad intelectual y la base sobre la cual se asientan los regímenes del mundo en esta materia. En efecto los ADPIC, señalan los requisitos que deben cumplir las invenciones para que sean protegidas a través de patentes: novedad, nivel inventivo y aplicación industrial, los cuales no estaban incluidos en el Convenio de Paris.

En el mundo hay una serie de Acuerdos Multilaterales en materia de Propiedad Industrial administrados por la Organización Mundial de la Propiedad Intelectual OMPI (Arana, 2014). Los Convenios administrados por la OMPI suscritos por el Perú son: El Convenio de la OMPI, el Convenio de París, el Tratado de Budapest sobre el reconocimiento internacional del depósito de microorganismos a los fines del procedimiento en materia de patentes, el Arreglo de Lisboa relativo a la protección de las denominaciones de origen y su registro internacional, el Tratado de Nairobi sobre protección del símbolo Olímpico, el Arreglo de Niza sobre la clasificación internacional de productos y servicios para el registro de Marcas, el Tratado de Cooperación en Materia de Patentes - PCT ${ }^{35}$ y el Tratado sobre el Derecho de Marcas - TLT sobre armonización de marcas y su registro.

En nuestro país, la norma más predominante en el sistema de propiedad intelectual es la Decisión 486 - Régimen Común de Propiedad Propiedad Industrial. La Decisión 486 es de carácter regional y es válida en los países pertenecientes a la Comunidad Andina. Conjuntamente con la Decisión 486, el Decreto Legislativo 1075 (modificado por la Ley 29316) que dispone algunas precisiones sobre la Decisión 486 es una de las normas principales en nuestro país. El Decreto Legislativo 1075 determina los montos máximos de las multas vinculadas a quienes violen derechos de propiedad industrial $\mathrm{u}$ obstaculicen los procedimientos. También desarrolla algunos aspectos procedimentales

\footnotetext{
${ }^{35}$ En el caso de la presentación de una solicitud internacional bajo el sistema PCT, se tiene hasta 30 meses para ingresar en fase nacional y validar la fecha de la primera presentación.
} 
y da plazos para su otorgamiento.

\subsection{Licencia Obligatoria: Marco Legal.}

La licencia obligatoria es quizás el mecanismo más dominante establecido en los ADPIC de todas las salvaguardas. La licencia obligatoria se puede definir como una "autorización que da un Estado para producir un producto patentado o para utilizar un procedimiento patentado sin el consentimiento del titular de la patente. El titular de la patente está forzado a tolerar que un tercero realice actos de explotación sin su consentimiento" según (Moncayo, 2010). El hecho que la licencia obligatoria pueda ser utilizada sin el consentimiento del titular de la patente la convierte en un arma de doble filo ya que los gobiernos puedan utilizarla como una amenaza a efectos de conseguir mejores precios de los medicamentos o pueden imponer licencias obligatorias sin parangón ahuyentando la inversión extranjera.

En el artículo 31 literal b) del acuerdo ADPIC se menciona que solo podrá permitirse el uso de la patente sin la autorización del titular cuando previamente el potencial usuario haya intentado obtener la autorización del titular de los derechos en términos y condiciones comerciales razonables y esos intentos no hayan surtido efecto en un plazo prudencial. Los Estados miembros podrán eximir de esta obligación en caso de emergencia nacional o en otras circunstancias de extrema urgencia, o en los casos de uso público no comercial.

En nuestro país, la norma que aborda el tema corresponde a la Decisión 486 de la Comunidad Andina (CAN), Régimen Común sobre Propiedad Industrial y el Decreto Legislativo 1075, Disposiciones Complementarias a la Decisión 486 de la Comisión de la Comunidad Andina que establece el Régimen Común sobre Propiedad Industrial. La autoridad recae sobre la Dirección de Invenciones y Nuevas Tecnologías del INDECOPI, la que deberá establecer el alcance o extensión de la licencia, debiendo especificar el periodo por el que se concede y su objeto.

La decisión 486 de la Comunidad Andina señala que se puede conceder una 
licencia obligatoria en los siguientes casos:

1. Falta de explotación: Por falta de uso por más de tres años de concedida la patente o cuatro años desde que se presentó su solicitud de registro. Se indica como condición, además, que la licencia obligatoria sólo será otorgada cuando el solicitante haya intentado previamente obtener una licencia contractual del titular de la patente.

2. Interés público, emergencia o seguridad nacional: Previa solicitud de un País miembro por la existencia de razones de interés público, de emergencia, o de seguridad nacional y solo durante el tiempo que estas razones permanezcan. Señala, además, que la licencia en cuestión será otorgada por la oficina nacional competente.

3. Por prácticas que afecten la libre competencia: De oficio o a petición de parte, la oficina nacional competente puede otorgar licencias obligatorias cuando la autoridad competente en materia de competencia haya determinado que el derechohabiente ha desarrollado conductas de abuso de posición de dominio en el mercado.

4. Licencia cruzada o patente dependiente: El INDECOPI otorgará licencia en cualquier momento, si ésta es solicitada por el titular de una patente, cuya explotación requiera necesariamente del empleo de otra, siempre y cuando dicho titular no haya podido obtener una licencia contractual en condiciones comerciales razonables.

El INDECOPI está facultado para modificar la licencia cuando nuevos hechos o circunstancias lo justifiquen a solicitud de parte. Ello permite que las partes continúen en tratativas para el otorgamiento de una licencia voluntaria, aun una vez otorgada la licencia obligatoria. 
Si bien las licencias obligatorias, en la práctica, habilitan a un tercero no titular de la patente a utilizar y explotar un producto patentado sin la autorización de su titular, este es un mecanismo que se restringe a casos muy específicos y debidamente determinados por el marco legal (Tassano, 2015). En esa línea, es importante resaltar que otorgar una licencia obligatoria no tiene como finalidad reducir la protección concedida a las empresas titulares de estos derechos de propiedad intelectual. Por el contrario, la autoridad administrativa únicamente deberá intervenir cuando se demuestre que la negativa a conceder licencias perjudica el bienestar del consumidor a corto y largo plazo.

El artículo 40 del Decreto Legislativo $\mathrm{N}^{\circ} 1075$ señala que para obtener una licencia obligatoria por razones de interés público, de emergencia o de seguridad nacional, el estado debe emitir la existencia de dichas circunstancias mediante decreto supremo, y solo mientras estas razones permanezcan, en cualquier momento se podrá someter la patente a licencia obligatoria. En tal caso, se otorgarán las licencias que se soliciten. El titular de la patente objeto de la licencia será notificado cuando sea razonablemente posible.

La Dirección de Invenciones y Nuevas Tecnologías establecerá el alcance de la licencia obligatoria, especificando en particular, el período por el cual se concede, el objeto de la licencia, el monto y las condiciones de la compensación económica. Dicho procedimiento ha sido recogido en el proyecto de "Directiva sobre normas aplicables al procedimiento de emisión de licencias obligatorias" emitido por la Dirección de Invenciones y Nuevas Tecnologías publicado mediante Resolución de la Presidencia del Consejo Directivo del INDECOPI N ${ }^{\circ}$ 059-2015-INDECOPI/COD del 7 de abril del $2015 .{ }^{36}$

El Proyecto de Directiva debe ser mejorado a la luz de las experiencias internacionales en la emisión de licencias obligatorias ya que la falta o deficiencias en las directrices para su aplicación la convierten en un arma de doble filo debido a que los

\footnotetext{
${ }^{36}$ El proyecto de Directiva aplicable al procedimiento de emisión de licencias obligatorias establece los requisitos de la solicitud, el procedimiento general y las disposiciones específicas para los distintos supuestos de licencia obligatoria entre otras consideraciones.
} 
gobiernos puedan utilizarla como una amenaza a efectos de conseguir mejores precios de los medicamentos o pueden imponer licencias obligatorias sin parangón justamente por la falta de lineamientos de la misma.

Por ejemplo, resulta necesario establecer lineamientos para la determinación de regalías impuestas por la Autoridad a la patente. Asimismo, es mandatorio establecer un procedimiento para el trámite de la declaratoria de existencia de razones de interés público que refiere el artículo 65 de la Decisión 486 de la Comisión de la Comunidad Andina debido a que la inexistencia de un procedimiento de este tipo puede inducir a que no se determine correctamente cuando existe un interés público o emergencia nacional. Los casos mencionados son solo algunas deficiencias que debe superar el actual Proyecto de Normativa. En el capítulo siguiente tocaremos más a detalle las consideraciones que debe tomar en cuenta el Proyecto en cuestión.

A continuación veremos ejemplos de los distintos usos que se le ha dado a la licencia obligatoria alrededor del mundo a efectos de recopilar cuáles fueron los beneficios y perjuicios que trajeron a colación la implementación de una licencia obligatoria.

\subsection{Uso de la licencia obligatoria en el mundo.}

Los organismos gubernamentales de salud de varios países utilizan la licencia obligatoria como amenaza para frenar los precios de los medicamentos seleccionados, en especial los referidos para el tratamiento de VIH/SIDA. A menudo las amenazas y negociaciones se mantienen en secreto. Sin embargo, la discusión de las licencias obligatorias en los productos farmacéuticos se hizo pública a partir de la emisión de las licencias obligatorias para combatir la epidemia del VIH en Sudáfrica (Lybecker \& Fowler, 2009). Al otro lado del mundo, en abril de 2007, el presidente de Brasil firmó un pedido de una licencia obligatoria para el uso del gobierno de la patente de Merck en un fármaco antirretroviral (Efavirenz), en un acto público que fue transmitido en todo el mundo (Cohen J. , 2007).

Todas estas licencias fueron emitidas bajo la autoridad de las disposiciones 
existentes al amparo del artículo 31 de los ADPIC. En el 2007, Ruanda (Organización Mundial del Comercio) emitió una licencia obligatoria para medicamentos contra el SIDA que no podía producir a nivel local y solicitó la ayuda de Canadá, generando la primera serie de licencias obligatorias back to back en virtud de las disposiciones establecidas en el párrafo 6 de la Declaración Ministerial de Doha. El año 2008, bajo el marco de las licencias obligatorias, Indonesia (Tunsarawuth, 2007) amenazó a compañías farmacéuticas para la reducción los precios de sus medicamentos, y en caso no estuvieran dispuestas a bajar los precios las expulsará. Como resultado de ello, la empresa farmacéutica Roche ha seleccionado socios en esos países para ayudar en la fabricación de un suministro suficiente de Tamiflu para combatir la gripe asiática.

Las amenazas de concesión de licencias obligatorias que condujeron a acuerdos con las principales compañías farmacéuticas según informes, se habían iniciado en Malasia (2004), Indonesia (2004), Brasil (2003), Zambia (2004), Zimbabwe (2004) y Mozambique (2004) en (Packard, 2007).

Incluso en 2001, el gobierno de los Estados Unidos contempló la posibilidad de una concesión de una licencia obligatoria sobre la ciprofloxacina, destinada a almacenar como una defensa contra el ántrax debido a los ataques terroristas de ese mismo año. En respuesta a la amenaza, Bayer redujo drásticamente el precio del medicamento (Carroll \& Winslow, 2001). Cabe señalar que la amenaza de licencia obligatoria debido a una urgencia nacional por parte del principal propulsor del sistema de la propiedad intelectual fue la excusa perfecta para promover la elaboración de la Declaración de Doha.

Asimismo, en el 2005, el gobierno belga adoptó medidas aún más amplias que permiten a las autoridades conceder licencias obligatorias en el interés de la salud pública en general con procedimientos acelerados en caso de una crisis de salud pública. Estas disposiciones no basan su autoridad en el artículo 31 de los ADPIC, sino que justifican la licencia obligatoria en virtud de los artículos 8 y 30 del Acuerdo sobre los ADPIC que, respectivamente, permiten "las medidas necesarias para proteger la salud pública" y establecen excepciones limitadas a los derechos exclusivos del titular de la patente 
establecidos en el artículo 28.1 del ADPIC. ${ }^{37}$

A pesar de que el gobierno belga no haya utilizado hasta ahora las licencias obligatorias, la presencia de este mecanismo aporta presión sobre titulares de patentes no-cooperativos y sirve como un argumento convincente para arrastrarlos a un acuerdo de licencia voluntaria (Van Zimmeren \& Requena, 2007).

En el 2006, dos licencias obligatorias sobre medicamentos contra el SIDA fueron otorgadas por las autoridades de Tailandia bajo un uso "no comercial". ${ }^{38}$ El ministro de salud, el Dr. Mongkol afirmó que Tailandia estaba considerando emitir licencias obligatorias para otros once medicamentos en la lucha contra el VIH/SIDA, el cáncer y las enfermedades del corazón (De Roo, 2011). El Wall Street Journal arremetió contra Tailandia por el incumplimiento de por lo menos el espíritu de los ADPIC porque "es difícil argumentar que Tailandia tiene una epidemia de SIDA, cuando su incidencia es de apenas encima del $1 \%$ a diferencia de países como Sudáfrica donde la tasa es del 20\%". Lo mismo ocurre con las licencias obligatorias dadas para los medicamentos para contrarrestar enfermedades del corazón de la población (Theft in Thailand, 2007). Otra editorial informó que "las patentes pueden ser liberadas en situaciones de emergencia; sin embargo, es difícil argumentar que las enfermedad cardíacas cumpla con esa característica" (Bate, 2007).

En Latinoamérica no hay casos de licencia obligatoria por razones de interés público, salvo Ecuador y Brasil. El 14 de abril de 2010 el Gobierno del Ecuador concedió una licencia obligatoria por razones de interés público para el medicamento antirretroviral Ritonavir a favor de la compañía farmacéutica Cipla cuyo distribuidor local es Eskegroup SA. El titular de la patente es Abbott Laboratories, el cual recibirá regalías por el periodo

\footnotetext{
${ }^{37}$ Una patente conferirá a su titular los siguientes derechos exclusivos: i) cuando la materia de la patente sea un producto, el de impedir que terceros, sin su consentimiento, realicen actos de: fabricación, uso, oferta para la venta, venta o importación para estos fines del producto objeto de la patente; ii) cuando la materia de la patente sea un procedimiento, el de impedir que terceros, sin su consentimiento, realicen el acto de utilización del procedimiento y los actos de: uso, oferta para la venta, venta o importación para estos fines de, por lo menos, el producto obtenido directamente por medio de dicho procedimiento.

${ }^{38}$ El ministro de Salud justificó la emisión de licencias ya que "tiene que proporcionar servicios de salud a cuarenta y nueve millones de personas con recursos limitados".
} 
establecido en la licencia obligatoria.

Colombia ha recibido solicitudes de licencia obligatoria y declaratoria de interés público para el medicamento Kaletra, sin embargo la Superintendencia de Industria y Comercio negó la expedición de la licencia obligatoria, tras discusiones con el Ministerio de Salud (de Protección Social, en ese momento) sobre quién era el competente para declarar las razones de interés público o necesidades de salud.

Los casos mencionados son solo algunas de las experiencias más mencionadas en el ámbito mundial y regional. En el Perú no ha existido una discusión tan avanzada para la emisión de licencias obligatorias a diferencia de Ecuador, Brasil y Colombia. De dichas experiencias se ha podido recoger importante información que nos permite evitar que se cometan los mismos errores y recoger lo mejor de las licencias obligatorias emitidas.

\subsection{Consecuencias del abuso de las licencias obligatorias.}

El uso adecuado de la licencia obligatoria puede salvar millones de vidas y mejorar la salud pública de decenas de naciones (Bird, 2009, pág. 209). Sin embargo, el otorgamiento de una licencia obligatoria genera costos secundarios que pueden ahogar los beneficios de un mayor acceso a los medicamentos a futuro (Bird, 2009).

El profesor Bird en (Reichman, 2009, pág. 253) señala que los principales costos del abuso de una licencia obligatoria son los siguientes:

- La inversión directa de los titulares de las patentes se vería disminuida, ya que los titulares de patentes buscan entornos más amigables.

- Las licencias obligatorias reducirán los incentivos del sector farmacéutico para innovar.

- Riesgo de que el otorgamiento abusivo de una licencia obligatoria pueda desencadenar represalias con sanciones comerciales que podrían paralizar la economía de la nación. 
Pues bien, al conceder una licencia obligatoria la inversión en el fármaco no puede ser devuelta una vez que la licencia entre en vigor. El problema subyacente se debe a que una vez que se emita, el incentivo para invertir en el futuro se reduce. Como consecuencia, esta reducción de la inversión en investigación e infraestructura tendrá efectos negativos en la población al limitar el acceso de los medicamentos.

Por ello, se señala que el uso inapropiado de las licencias obligatorias tiene el potencial de quebrar el buen funcionamiento de los mercados farmacéuticos y generar un retroceso de inversión en los países en los cuales se desarrollan. Por ejemplo, en respuesta a una licencia obligatoria otorgada por el gobierno de Tailandia, Abbott decidió desinvertir en el mercado tailandés a la espera de la reforma nacional del sistema de patentes. Asimismo retiró siete solicitudes de registro de patentes pendientes para nuevos medicamentos (The Associated Press, 2007). El repliegue de una inversión importante en el país genera mayores barreras para el acceso de medicamentos, lo que ocasiona un perjuicio en el acceso de medicamentos para los usuarios.

En este sentido, las empresas farmacéuticas por miedo a no recuperar los costos de investigación y desarrollo, dejarán de dedicar su tiempo y dinero en el descubrimiento de nuevas curas para enfermedades infecciosas o tropicales, que son irónicamente, las de mayor incidencia en los países en desarrollo y, en su lugar, se centrarán totalmente en medicinas mucho más rentables para los países desarrollados.

Se teme que el problema de obtener el acceso a los medicamentos necesarios para hacer frente a la pandemia del VIH/SIDA se pueda ver afectado por disposiciones intervencionistas en relación con la propiedad de las patentes generando una mayor escasez de estos medicamentos, puesto que, como señala el Dr. Wainberg, la ganancia otorgada por las patentes es el único estímulo de la industria farmacéutica para continuar la investigación del SIDA (Tesher, 2000). Esta clase de incentivo no resulta necesario en los laboratorios que comercializan medicamentos genéricos ya que no han incurrido en los costos de I+D. 
A decir de Otamendi, los copistas no son personas a las que les interesa que la población más susceptible tenga acceso a fármacos con precios accesibles, sino que, por el contrario, son personas a quienes les interesa poco la salud pública, les interesa más el rédito gigantesco que obtienen con la copia de dichos medicamentos. Asimismo, señala que a mediados del siglo diecinueve, el promedio de vida era de 40 años preguntándose “¿quiénes contribuyeron más a que tengamos hoy un promedio de vida superior a los setenta años en muchos países? ¿Los que copian o los que investigan?” (Rodriguez Spinelli, 2008).

Por otro lado, las represalias tomadas contra el país otorgante de licencias obligatorias por un abuso de éstas en el caso más extremo pueden concluir con sanciones comerciales, así como con castigos pecuniarios por una eventual expropiación de la propiedad. Como es sabido, los Tratados de Libre Comercio o simplemente TLCs, contienen disposiciones sobre expropiación. Dada la naturaleza de la licencia obligatoria por motivos de interés público, los inversores en la industria farmacéutica no tendrán una reclamación por expropiación directa, pero sí por expropiación indirecta ${ }^{39}$ en caso su derecho de propiedad se reduzca sustancialmente y cuyos efectos serían equivalentes a la plena expropiación (Zachary, 2004) ${ }^{40}$.

Aunque puede resultar difícil para un titular de una patente afectada afirmar que se ha producido una expropiación ilegal si se cumplen las normas del Acuerdo sobre los ADPIC pueden surgir casos en que se puedan formular reclamaciones por una inadecuada determinación de las regalías. Los derechos de los inversionistas pueden ser usados para

\footnotetext{
${ }^{39}$ La expropiación indirecta corresponde a aquellos actos estatales que en la práctica producen una pérdida de la administración, el uso o el control de un recurso, o una significativa depreciación en el valor de los bienes. Por ejemplo, las expropiaciones regulatorias son aquellas donde la afectación al derecho de propiedad se produce a través de regulación estatal. En el caso de la licencia obligatoria no se priva al titular de comercializar la patente. Sin embargo, se elimina el monopolio otorgado por el derecho de patente.

${ }^{40}$ Jan Paulsson y Zachary Douglas han escrito extensamente sobre el ámbito de la expropiación indirecta en la propiedad intelectual y sugieren dos etapas de análisis: i) en la primera se debe analizar la magnitud de la interferencia en el derecho de propiedad ii) analizar si dicha interferencia se eleva al nivel de la expropiación directa. Sin embargo, el caso de la expropiación indirecta sugiere el análisis de un tercer factor, a saber, el carácter y el motivo detrás de la acción gubernamental regulador sobre una base de caso por caso. Estos tres factores se han incorporado en el Anexo B del TLC modelo de EE.UU. para determinar la existencia de una expropiación indirecta.
} 
disuadir a los gobiernos de usar licencias obligatorias. Ahora bien, en el caso de nuestro país, en uno de los TLC más emblemáticos (TLC-USA) se ha implementado una excepción de indemnización y expropiación de licencias obligatorias en el artículo 10.7.5 que señala que "no se aplica a la expedición de licencias obligatorias otorgadas con relación a derechos de propiedad intelectual conforme con el Acuerdo ADPIC, o a la revocación, limitación o creación de derechos de propiedad intelectual en la medida que dicha expedición, revocación, limitación o creación sea compatible con el Capítulo Dieciséis (Derechos de Propiedad Intelectual)". Dicha excepción no evita que en otros TLC se permita reclamos de expropiación por una inadecuada imposición de licencias obligatorias, los cuales podrían terminar en sanciones que puedan afectar la dinámica de la economía en nuestro país.

Por último, uno de los puntos más complicados en la imposición de una licencia obligatoria es la determinación de regalías por parte de la autoridad, más aún cuando el INDECOPI carece de experiencia en estos temas. En sí la imposición de una licencia obligatoria conlleva una imposición unilateral de un precio determinado, sin embargo debe actuar con cautela para evitar caer en la trampa de convertirse en un regulador de precios.

Por ejemplo, el Departamento de Patentes de India concedió una licencia obligatoria, entre otras cosas, alegando que el medicamento Nexavar no estaba a disposición del público a un precio razonablemente asequible. Al hacerlo, el gobierno indio interpretó la expresión "precio razonablemente asequible" de tal forma que debe garantizarse la accesibilidad de los fármacos para la población india sin tener en cuenta los costes incurridos en la fabricación de los mismos. La incapacidad de Bayer de poner el medicamento Nexavar a disposición de casi el 98 por ciento del público indio fue el argumento gatillador para la emisión de la licencia obligatoria (Satarawala Chopra \& Muthappa, 2012). En este sentido, el objetivo de la Autoridad era bajar los precios debido a que eran muy elevados para la población.

Esta parte de la decisión es especialmente importante no sólo para los potenciales solicitantes de licencias obligatorias, sino también para los futuros solicitantes de 
patentes. Por un lado, esto plantea preguntas importantes acerca de cómo exactamente "un precio razonable" debe definirse desde una perspectiva pública. El gobierno indio ha enviado un claro mensaje que no permitirá a las compañías farmacéuticas establecer precios sin tomar en cuenta la posibilidad de acceso a dichos medicamentos para la totalidad de su población (Sood, 2013, pág. 109). El uso de un estándar ambiguo en nuestro país como el usado por el gobierno indio podría aumentar el alcance de la subjetividad para la determinación de regalías y promover abusos en la aplicación de licencias obligatorias.

La aplicación de una licencia obligatoria por interés público como la solicitada en nuestro país para el medicamento Atazanavir no es un procedimiento libre de consecuencias económicas graves. En la coyuntura actual del país que tiene como prioridad el fortalecimiento de los derechos de propiedad intelectual para atraer la inversión extranjera es necesario contar con una normativa lo suficientemente sólida que tenga la capacidad de por lo menos responder a las preguntas derivadas de su aplicación. Asimismo, la emisión de dicha normativa debe contener un estudio costo-beneficio considerando los perjuicios que podría ocasionar su aplicación. En vista de la falta de lineamientos, en el último capítulo de la presente tesis he recopilado algunas consideraciones que podrían ser incluidas en el Proyecto de normativa de licencia obligatoria, las cuales tienen por objeto de garantizar el equilibrio entre en el acceso a la salud y la protección de los derechos de propiedad intelectual. 


\section{CAPÍTULO IV: SISTEMA DE PATENTES EN EL SECTOR FARMACÉUTICO}

\subsection{Con mis patentes no te metas.}

Las ventajas y desventajas del sistema de patentes pueden intensificarse o disminuir dependiendo del mercado en el cual se aterrice ya que cada mercado tiene particularidades únicas que deben examinarse detenidamente. En el caso en concreto de la industria farmacéutica, varios autores como Cole, que critican el sistema actual de propiedad intelectual concuerdan que las patentes sí deberían ser aplicadas a la industria química y farmacéutica. El sistema de patentes resulta de mayor importancia por las razones presentadas a continuación.

En primer lugar, debemos advertir que, no obstante la vida legal de la patente es de veinte años, la vida efectiva de una patente en medicamentos es alrededor de ocho años, a causa del tiempo utilizado en el proceso de investigación y desarrollo, y trámites regulatorios antes del lanzamiento del producto al mercado. En la Figura 2 se muestra la situación expuesta (Gerencia de Estudios Económicos del INDECOPI, 2002). ${ }^{41}$

\footnotetext{
${ }^{41}$ Este gráfico mide el eje de ordenadas el flujo de caja del laboratorio. El punto A marca el inicio del período de comercialización del nuevo producto una vez aprobada la solicitud de patente. En el momento en que ésta expira (punto B), los ingresos netos caen debido a la entrada de los genéricos y siguen la trayectoria BCD. La magnitud de la caída de los ingresos (distancia BC) dependerá de otras barreras a la entrada que encuentren los productos genéricos.
} 
Figura 2. Evolución del flujo de caja para la creación de un nuevo producto farmacéutico.

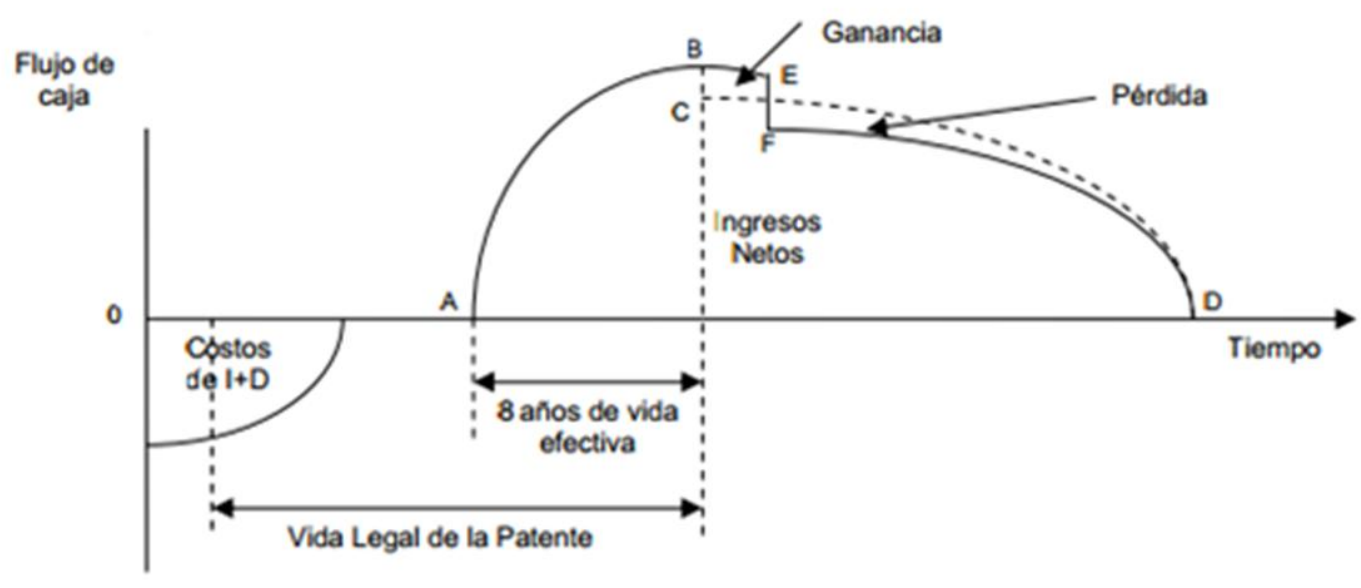

Teniendo en cuenta la vida efectiva real de estos productos, en Estados Unidos los laboratorios solicitaron la extensión del período de vida legal de las patentes para compensar una parte de los años perdidos en el proceso previo a la comercialización del producto. Las presiones terminaron en 1984 con la aprobación de la Ley de Competencia en Precios de los Productos Genéricos y de Restauración de Patentes denominada "HatchWaxman Act". Esta ley establece una extensión de la vida efectiva de las patentes igual a la suma del período de revisión del organismo competente, más la mitad del período de pruebas clínicas (dando un total de 5 años en promedio) (Schacht \& Thomas, 2002). Lamentablemente, esta posibilidad no está disponible en el Perú según la Decisión 486 y la normativa nacional.

En este punto es necesario resaltar que el riesgo asociado a la investigación y desarrollo en la industria farmacéutica es particularmente alto, uno de cada cuatro mil medicamentos descubiertos en última instancia se comercializan y los costos de cada producto oscilan entre 200 y 400 millones de dólares (Gerencia de Estudios Económicos del INDECOPI, 2002). Estos números son importantes en la evaluación del valor monetario esperado, en adelante VME, para participar en la investigación y desarrollo de productos farmacéuticos. Asimismo, la teoría económica en general, asume que "las organizaciones empresariales son neutrales al riesgo", y que, como tal, buscarán maximizar su VME. Una empresa tendrá en cuenta diversos cursos de acción con 
diferentes valores y proseguirá el curso de acción que ofrece el más alto VME (Bailey, 2001).

La importancia de las patentes para la innovación farmacéutica ha sido demostrada en varios estudios económicos. Richard Levin y Wes Cohen han llevado a cabo encuestas en una amplia sección transversal de industrias para identificar qué factores son los más importantes y necesarios en la apropiación de los beneficios de la innovación (Cohen W. , 1997). Estos factores incluyen la competitividad, ventajas de ser primero en el mercado, las ventas superiores y esfuerzos de servicio, el secreto y la complejidad de la producción y la tecnología del producto, así como las patentes. En ambos estudios encontraron que la industria farmacéutica coloca la mayor importancia a las patentes.

Los hallazgos de estos estudios están de acuerdo con un estudio anterior realizado por los economistas británicos Taylor y Silberston. Basado en un estudio de Reino Unido realizados a gerentes de $\mathrm{I}+\mathrm{D}$, se estima que los gastos de $\mathrm{I}+\mathrm{D}$ farmacéutico se reducirían en un 64 por ciento en ausencia de la protección de patentes. Por el contrario, la reducción correspondiente a todas las demás industrias bajo encuesta fue de sólo el 8 por ciento. ${ }^{42}$

Asimismo, una encuesta actual realizada por la Universidad de Berkeley (Sichelman, Samuelson, \& Merges, 2010) indica que los inversores otorgan una gran importancia a las patentes cuando se toman decisiones de inversión. De hecho, el 67\% de las empresas encuestadas indicó que la existencia de patentes es un factor importante en sus decisiones de inversión. El mayor porcentaje lo registran las empresas de biotecnología (73\%) y las empresas farmacéuticas y de dispositivos médicos (85\%), lo que demuestra que no importa la industria, en la mayoría de los mercados se le da una gran importancia a las patentes cuando se toman decisiones de financiación.

Ahora bien, uno de los criterios que debe tomarse en cuenta al establecer un

\footnotetext{
${ }^{42}$ Hallazgos similares fueron reportados por Edwin Mansfield de una encuesta a los directores de investigación de 100 corporaciones en USA.
} 
sistema de protección de patentes es el costo de inventar como el costo de copiar; entre más alta sea la ratio de aquel con respecto a éste, más óptima es la protección por patentes para el inventor. En el caso particular de los fármacos, la ratio es bastante alta. El costo de inventar un nuevo fármaco - costo que incluye las extensivas pruebas requeridas para que se apruebe la venta de éste- es de cientos de millones de dólares, mientras que, para la mayoría de fármacos, el costo de copiarlos -o de producir un substituto idéntico- es muy bajo. Por lo tanto, la ratio del primer al segundo costo va a ser siempre alta, lo cual hace difícil que el inventor recupere sus costos sin protección por patentes (y por las razones adicionales de que el valor de los ingresos por la venta del fármaco se devalúa por el tiempo que demora en aprobarse, y que el plazo efectivo de la patente es truncado porque el periodo de protección de la patente empieza a correr cuando la patente es solicitada en vez de, años después, cuando el fármaco puede empezar a venderse) en (Becker \& Posner, 2012).

Si no existieran las patentes, los productos genéricos equivalentes podrían entrar libremente y la competencia obligaría a bajar los precios al costo marginal, con lo cual las empresas tendrían lo suficiente para cubrir los costes de producción y distribución. Sin embargo, la fijación de precios de costo marginal no puede generar ingresos suficientes para cubrir los costos de I + D de las empresas innovadoras. Por tanto, el objetivo económico de las patentes es impedir la entrada de copias en el mercado para proporcionar a la empresa innovadora una oportunidad de establecer un precio superior al coste marginal con el fin de preservar los incentivos para futuros proyectos de I + D.

\subsection{Críticas al sistema de patentes en el sector farmacéutico.}

\subsubsection{Distorsión financiera.}

Una de las mayores críticas a la configuración del sistema de patentes es la distorsión financiera. En el marco del sistema de patentes, especialmente en el sector farmacéutico, la investigación se financia con los beneficios del monopolio. Sin embargo, parte del problema es que gran parte de los ingresos obtenidos se utiliza para financiar investigaciones que no generan un beneficio para la sociedad. Las investigaciones subvencionadas por estos ingresos no corresponden a los objetivos sociales adecuados: 
se financia medicamentos de estilo de vida, tales como para la regeneración del cabello y no medicamentos que mejoran la calidad de vida. Por lo tanto, para Stiglitz existe una gran cantidad de lo que se podría llamar "fugas" al no entregar los ingresos a las áreas importantes de la investigación.

Podemos considerar que el diferencial entre el precio de un producto patentado y el costo marginal del mismo es una especie de tributo. A decir de (Stiglitz, 2008, pág. 1713) el diferencial entre el precio de un producto patentado y el costo marginal del mismo puede ser considerado un impuesto: el sistema de patentes resulta la combinación de un sistema de precios competitivos con un impuesto por unidad producida (la diferencia entre el precio y el costo marginal de producción), el cual es dedicado a financiar la investigación.

Desde una perspectiva de bienestar social no es adecuado que una persona con una enfermedad terminal tenga que financiar con el pago de sus impuestos medicamentos de estilo de vida. Un impuesto sobre medicamentos de enfermedades mortales es injustificable a menos que se garantice que todos esos ingresos son destinados a la investigación de ese tipo de enfermedades. ${ }^{43}$

\subsubsection{Precios elevados.}

La objeción a las patentes en los países en desarrollo supone que los titulares de patentes tienen la posibilidad de fijar precios significativamente superiores al coste marginal. Sin embargo, a pesar de que las patentes pueden, en teoría, permitir a una empresa para cobrar un precio superior al coste marginal, puede que ello no sea de interés para la empresa en mercados donde la mayoría de consumidores no pueden adquirir los farmacéuticos patentados: si los precios son muy altos nadie los comprará. Los titulares de las patentes pueden establecer racionalmente los precios cerca de costo marginal en los mercados de bajos ingresos con una alta elasticidad, y de hecho hacer realizar ello les garantiza una

\footnotetext{
${ }^{43}$ Uno de los principales avances en las finanzas públicas en los últimos treinta años es el estudio del impacto de los impuestos que provocan distorsiones y de distribución de los sistemas tributarios. Si consideramos el sistema de propiedad intelectual como un impuesto podríamos considerarlo como uno de los que generan más distorsiones.
} 
mayor cantidad ingresos, a condición que estos precios bajos no afecten otros mercados con una demanda de baja elasticidad, ya sea por precios de referencia (control de precios) o por importaciones paralelas.

En el capítulo siguiente analizaremos la lógica de los precios de los medicamentos patentados, lo cual nos permitirá tener un panorama más claro acerca de viabilidad de adoptar alguna medida tal como una licencia obligatoria contra los precios altos de los medicamentos. 


\section{CAPÍTULO V: ¿PRECIOS SIN PARANGÓN?}

La fijación de precios por encima de los costos marginales crea dos pérdidas para los consumidores. La primera es el precio adicional que los consumidores pagan por adquirir un medicamento a precio de monopolio, ya que los usuarios pagarían un precio menor a un productor competitivo.

La segunda pérdida corresponde a la "pérdida de eficiencia" o "pérdida de peso muerto" de las transacciones no realizadas que habrían tenido lugar a un precio competitivo. En los mercados farmacéuticos, la pérdida de eficiencia corresponde al problema del "acceso" de medicamentos: la población de escasos recursos no puede adquirir un producto farmacéutico debido a su alto precio, y como resultado no reciben tratamiento. Dicha situación adquiere una importancia de mayor relevancia en los casos de no acceso de medicamentos esenciales para la vida y la salud.

Ahora bien, (Flynn, Hollis, \& Palmedo, 2009) nos explican que los precios de los productos patentados no son irracionales, el monopolista siempre se encuentra limitado por el mercado. Si los precios son muy altos, entonces algunas personas no podrán pagarlo y por lo tanto no lo comprarán. En ese sentido, el monopolista pierde demasiados clientes. 
Figura 3. Curva de demanda lineal.

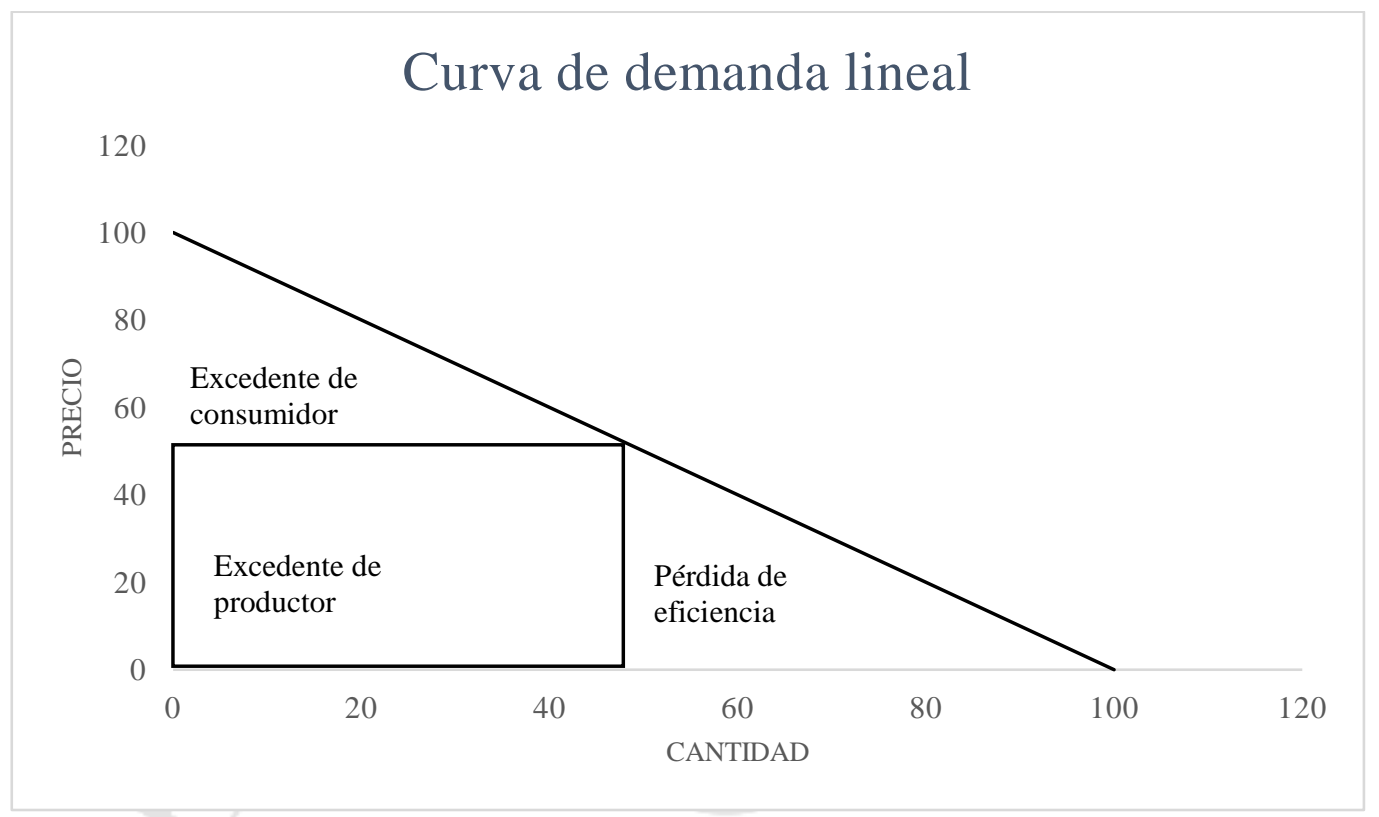

Fuente: Elaboración propia.

En el gráfico anterior, se puede observar que si el precio es cercano a cero la cantidad demandada sería de 100. En ese caso, no habría pérdida de eficiencia ya que todos los que se encuentran dispuestos a pagar un precio competitivo van a adquirir el producto.

Ahora bien, el monopolista escogerá el precio que maximiza los beneficios para cualquier curva de demanda, elevando el precio hasta que el producto del precio por el número de personas que puedan pagar dicho precio sea el más rentable para el monopolista. En la Figura 3, el vendedor podría vender una cantidad de 99 bienes por 1 sol, produciendo ventas de S/ 99. Se puede aumentar el precio de $\mathrm{S} / 2$ y va a perder una venta (la pérdida de 98 en lugar de 99 por el aumento de precio se denomina pérdida de eficiencia). Sin embargo, el aumento de los ingresos compensa la pérdida de la demanda (que permite ganancias de S/ 196 en lugar de S/99). En este modelo, el monopolista dejará de aumentar los precios cuando vende 50 productos por S/ 50, ganando S/ 2500 en ventas. Más allá de este punto, el vendedor pierde dinero por las ventas perdidas a precios más altos conforme se puede apreciar en la Tabla 4. 
Tabla 4. Ingresos por precio y cantidad.

\begin{tabular}{|l|l|l|}
\hline Precio & Cantidad & Ingresos \\
\hline 1 & 99 & 99 \\
\hline 2 & 98 & 196 \\
\hline 49 & 51 & 2499 \\
\hline $\mathbf{5 0}$ & $\mathbf{5 0}$ & $\mathbf{2 5 0 0}$ \\
\hline 98 & 2 & 196 \\
\hline 99 & 1 & 99 \\
\hline
\end{tabular}

Por lo tanto, el precio que maximiza los ingresos, en adelante el Precio de Utilidad Máxima, es de S/ 50. En la Figura 3, el área debajo de la curva de demanda ya la derecha de 50 unidades corresponde a la "pérdida de eficiencia" como hemos explicado anteriormente. Los ingresos obtenidos por las ventas aparecen en como "excedente de productor" asumiendo que el costo marginal es casi igual a cero. Un punto importante de resaltar es que el excedente del productor de S/ 2500 es aproximadamente el doble que la pérdida de eficiencia, de modo que proporciona un fuerte incentivo para la innovación, en comparación con el costo social generado debido a la pérdida de eficiencia.

\subsection{Curva de demanda convexa.}

Las estrategias de precios que maximizan los beneficios para una empresa que tiene el monopolio se alteran por la forma y la pendiente de la curva de demanda. La pendiente de la curva de demanda puede verse afectado por la elasticidad de la demanda. Un monopolista será más moderado si los consumidores están más dispuestos a cambiar a su producto por un sustituto inferior o quedarse sin él en caso se realice un incremento de precio. Menor elasticidad significa que los consumidores no van a frenar su demanda por un incremento significativo de los precios, la cual se traduce en una curva de demanda vertical o pronunciada; mientras que una alta elasticidad significa que el aumento de precio más pequeño eliminaría todas las compras de los consumidores, la cual se plasma en una curva más plana en el plano horizontal. 


\subsection{El problema de la curva de demanda convexa.}

Las curvas de demanda que tienen algún elemento de convexidad indican que en un determinado segmento del mercado la demanda es muy elástica (la parte más plana de la curva) por lo cual dicho segmento renunciará a la compra si se incrementan ligeramente los precios. Es probable que la demanda sea más inelástica en otro segmento del mercado que se encuentra dispuesto a pagar precios más altos. A mayor convexidad mayor desigualdad del mercado o país y viceversa.

Figura 4. Curva de demanda convexa.

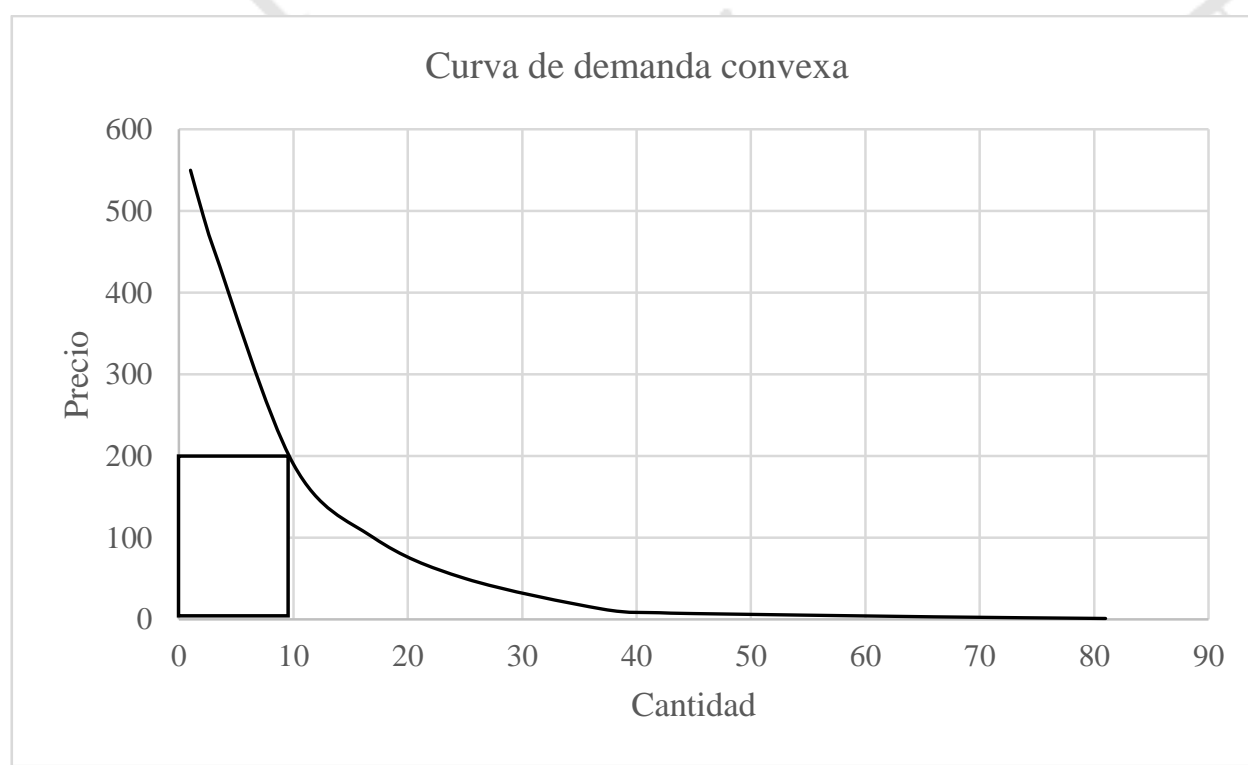

En la Figura 4 se puede apreciar que un ligero aumento de precios empuja un gran número de consumidores fuera del mercado. A su vez, se puede notar que en el segmento elástico de la curva (la parte más vertical-empinada de la curva) un gran aumento de precio produce un descenso mínimo en las ventas. Por lo tanto, el Precio de Utilidad Máxima sería aproximadamente 200, cuatro veces más alto que en la curva de demanda lineal de la Figura 3. En este caso, la pérdida de eficiencia (1835) es casi exactamente la misma que los ingresos, a diferencia que la curva lineal, donde la pérdida de peso muerto de 1225 es casi la mitad de los ingresos que son de 2500. Asimismo, únicamente una pequeña proporción de los posibles compradores (aproximadamente 10\%) compraría el producto (Flynn, Hollis, \& Palmedo, 2009). 
(Flynn, Hollis, \& Palmedo, 2009) señalan que el intercambio entre los incentivos para la innovación (ingresos) frente a las pérdidas de eficiencia de las curvas de demanda convexas no es tan favorable para el sistema de patentes como en las curvas de demanda lineales. La protección de patentes en la Figura 4 tiene un efecto menor en la innovación que en el caso de demanda lineal; y al mismo tiempo las pérdidas de eficiencia son más grandes.

El periodo de protección de las patentes refleja la voluntad de la sociedad para brindar incentivos a la innovación sacrificando precios competitivos (lo que significa una alta "pérdida de eficiencia"). Incluso, (Duffy, 2003) ha propuesto un periodo alternativo de protección a las patentes considerando la "pérdida de eficiencia" generada por un eventual monopolio. Según Flynn, Hollis, y Palmedo, un periodo de veinte años de explotación exclusiva brinda un incentivo suficiente para promover la innovación, más allá de ese periodo las pérdidas de eficiencia serán mucho más altas que los incentivos generados por la exclusividad.

En los mercados que tienen un ratio eficiencia-ingresos poco favorable como el mostrado en la Figura 4, el costo marginal de la protección de patentes es muy alto frente a los beneficios brindados, por lo que el período óptimo de protección - o el tipo de protección debe ser menor. Es bien sabido que el periodo de protección de las patentes es bastante criticado, ya que no se ha considerado las características de las patentes y el costo social involucrado, por lo tanto la conclusión de que las reglas de patentes estándar están mal adaptadas a los mercados con curvas de demanda convexa no resulta sorprendente. Las patentes deberían adaptar su funcionamiento a mercados que se caracterizan por curvas de demanda altamente convexas, en especial para los medicamentos esenciales (Flynn, Hollis, \& Palmedo, 2009).

En los países muy pobres que se caracterizan por la distribución desigual de ingresos, la acción lógica de las compañías que busquen maximizar las ganancias será cobrar precios más altos al sector acomodado de la sociedad, ya que se obtiene mucho más beneficios que si se hubiera distribuido el mismo producto a precios asequibles a la 
población con menos ingresos.

\subsection{Curva de demanda en Perú.}

La distribución del ingreso y la riqueza en los países en vías de desarrollo tiende a ser extremadamente desigual. ${ }^{44}$ La Figura 5 muestra la distribución del ingreso en Perú en forma de renta media per cápita anual para cada decil de la población al 2015. En dicha figura, se puede apreciar que el $20 \%$ más rico obtuvo el 50 por ciento de todos los ingresos. Asimismo, el 10\% más rico obtuvo un promedio de S/ 35268 anuales, casi 19 veces el ingreso promedio del 10\% más pobre sólo S/ 1860 anuales.

Figura 5. Ingreso promedio per cápita por deciles.

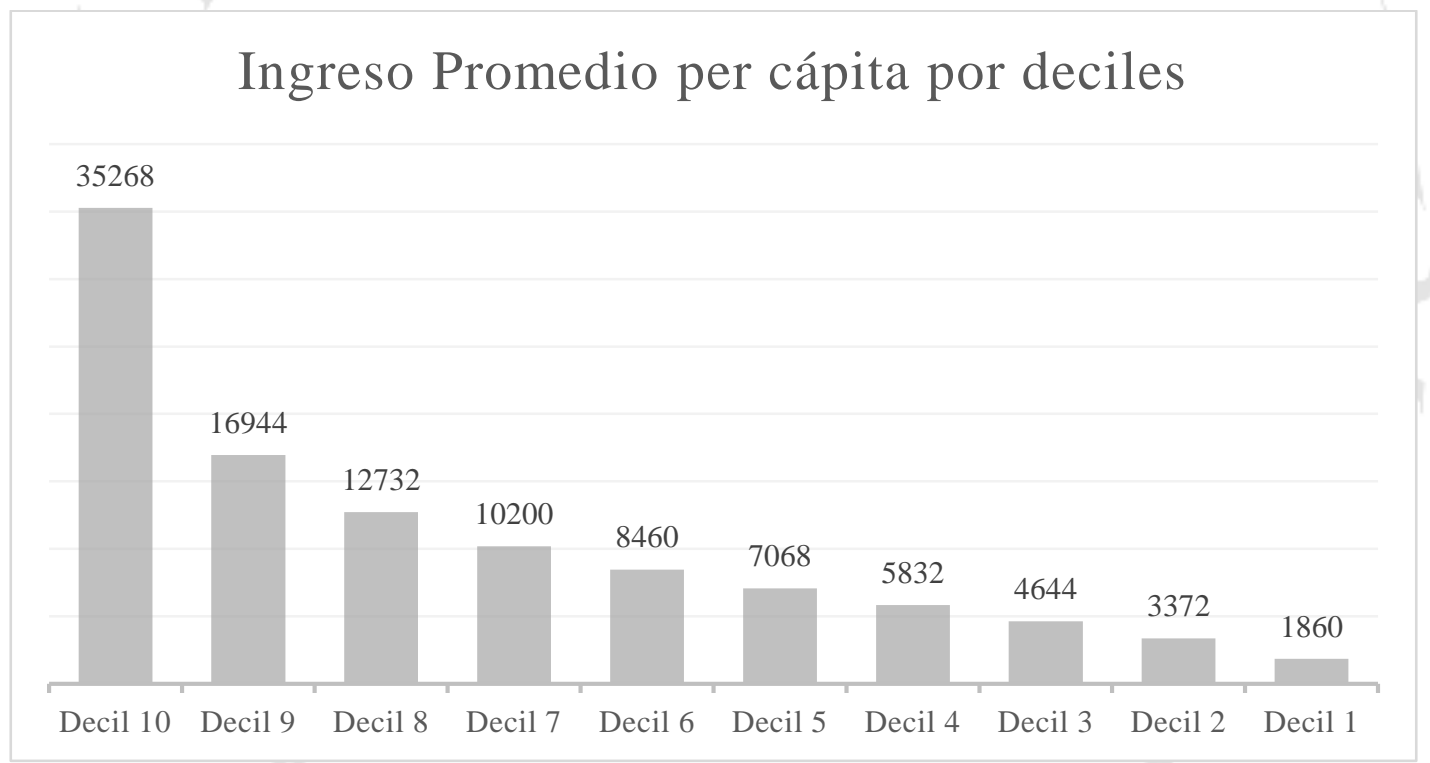

Elaboración Propia. Fuente: Evaluación de la Pobreza Monetaria 2009-2015. INEI. Ingreso en soles constantes base= 2015 a precios de Lima Metropolitana.

La alta desigualdad en la capacidad de pago de un país producirá curvas de demanda altamente convexas para artículos sensibles a los incrementos de precios. La Figura 6 es una curva de demanda para la medicina del SIDA en Perú construido de acuerdo al modelo de (Flynn, Hollis, \& Palmedo, 2009) bajo las reglas siguientes: (i) la capacidad de pago es proporcional a los ingresos anuales, y (ii) la incidencia de la enfermedad es igual entre todos los niveles de ingresos. La forma de la curva de demanda

\footnotetext{
${ }^{44}$ El índice de Gini en Perú es de 0.44 en el 2015 según Informe de la Pobreza Monetaria 2015. INEI.
} 
se puede utilizar para estimar el comportamiento de optimización de beneficios de un monopolio en este mercado. La Figura 6 supone que las personas que necesitan tratamiento contra el SIDA en Perú podrán adquirir un antirretroviral si el costo máximo es el 7\% de sus ingresos (INEI, 2016). Ello debido a que según el INEI la población gasta aproximadamente el $7 \%$ de su renta en atención médica.

Figura 6. Demanda antirretroviral en Perú.

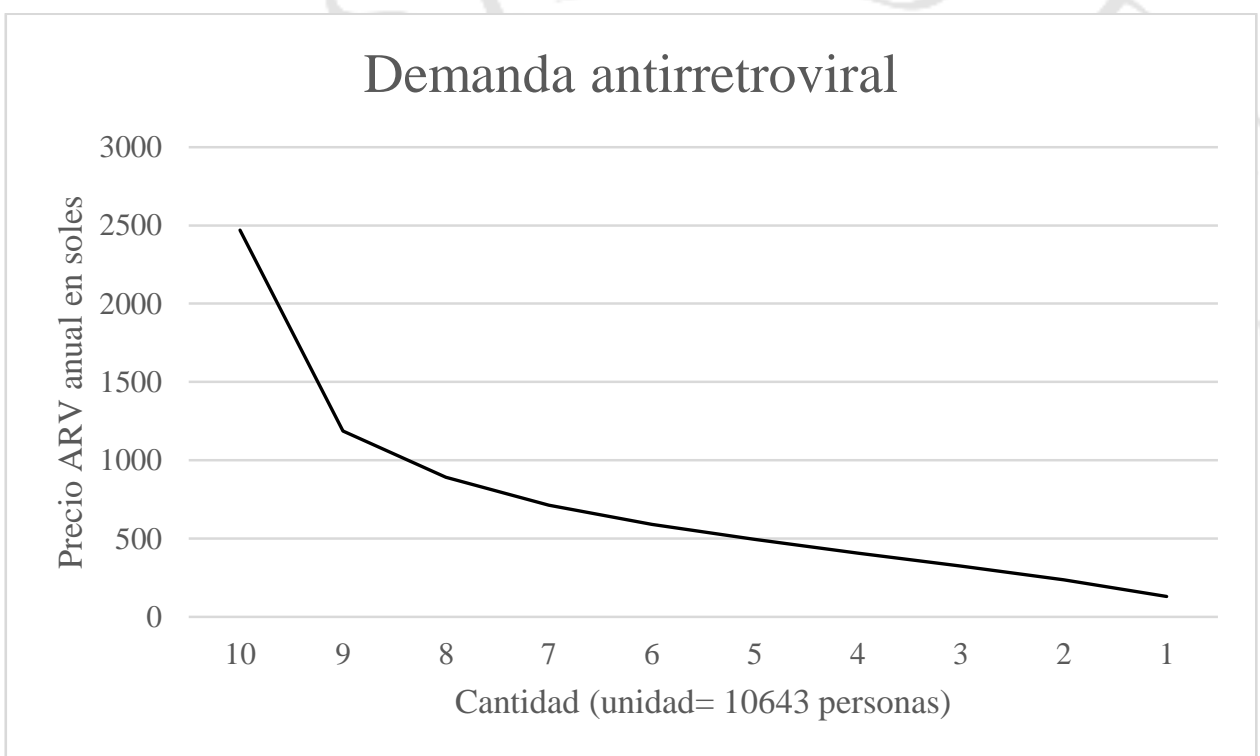

Elaboración propia. Precio 7\% de los ingresos.

De acuerdo con los datos del mes de abril del 2016 del Centro Nacional de Epidemiología, Prevención y Control de Enfermedades del Ministerio de Salud, 106426 personas viven con VIH/SIDA en el Perú. ${ }^{45}$ Tomando las reglas del modelo señalado en el párrafo anterior, cada decil de la Tabla 5 contiene 10643 personas que necesitarán tratamiento antirretroviral. Si se fija el precio anual de S/ 2469 por paciente, únicamente el decil con mayores ingresos podrá adquirir el medicamento. Con el fin de vender a todas las personas con SIDA que necesitan tratamiento, el precio tendría que bajar a S/ 130 soles anuales por paciente.

4534426 personas tienen SIDA en el Perú según el Boletín Epidemiológico Mensual (Abril 2016). Asimismo, 72000 personas tienen VIH según artículo publicado en La Republica el 29 de Noviembre del 2015. Disponible en http://larepublica.pe/impresa/sociedad/722032-los-avances-del-peru-en-la-durabatalla-contra-el-vih 
Tabla 5. Ingresos anuales antirretrovirales en Perú.

\begin{tabular}{|l|l|l|l|}
\hline Decil & \multicolumn{1}{l}{$\begin{array}{l}\text { Precio } \\
\text { ARV S/ }\end{array}$} & $\begin{array}{l}\text { Precio } \\
\text { ARV \$ }\end{array}$ & \multicolumn{2}{l|}{$\begin{array}{l}\text { Ventas Anuales } \\
\text { S/ }\end{array}$} \\
\hline 10 & 2469 & 734 & 26275012,68 \\
\hline 9 & 1186 & 353 & 25246898,88 \\
\hline 8 & 891 & 265 & 28456401,96 \\
\hline 7 & 714 & 212 & 30396408 \\
\hline 6 & 592 & 176 & 31513923 \\
\hline 5 & 495 & 147 & 31594384,08 \\
\hline 4 & 408 & 121 & 30414288,24 \\
\hline 3 & 325 & 97 & 27678611,52 \\
\hline 2 & 236 & 70 & 22609563,48 \\
\hline 1 & 130 & 39 & 13857186 \\
\hline
\end{tabular}

Elaboración propia. Tipo de cambio: 3.346 SUNAT: 31 de agosto del 2016

La Figura 7 muestra los ingresos por ventas totales de una empresa por cada precio de la curva de demanda. Si la empresa comercializa el farmacéutico a un precio que el $100 \%$ de la población puede acceder, se vería obligada a producir el doble perdiendo ingresos por más del doble (generaría ingresos únicamente por 13 millones).

De la Tabla 5 se puede observar que la empresa farmacéutica maximiza sus ventas en el Perú si comercializa el producto a un precio de 495 soles anuales que únicamente el 50\% de los pacientes con VIH/SIDA puede acceder obteniendo ingresos por aproximadamente 32 millones de soles anuales. En ese sentido, la empresa maximiza sus ingresos fijando un precio inalcanzable para el 50\% de la población. El Precio de Utilidad Máxima correspondiente a 495 soles sería el fijado por la industria farmacéutica en el Perú de no ser por el temor a que sea usado como "precio de referencia" en otros países, en los cuales podrían obtener ingresos muchos mayores. 
Figura 7. Ingresos por cantidad.

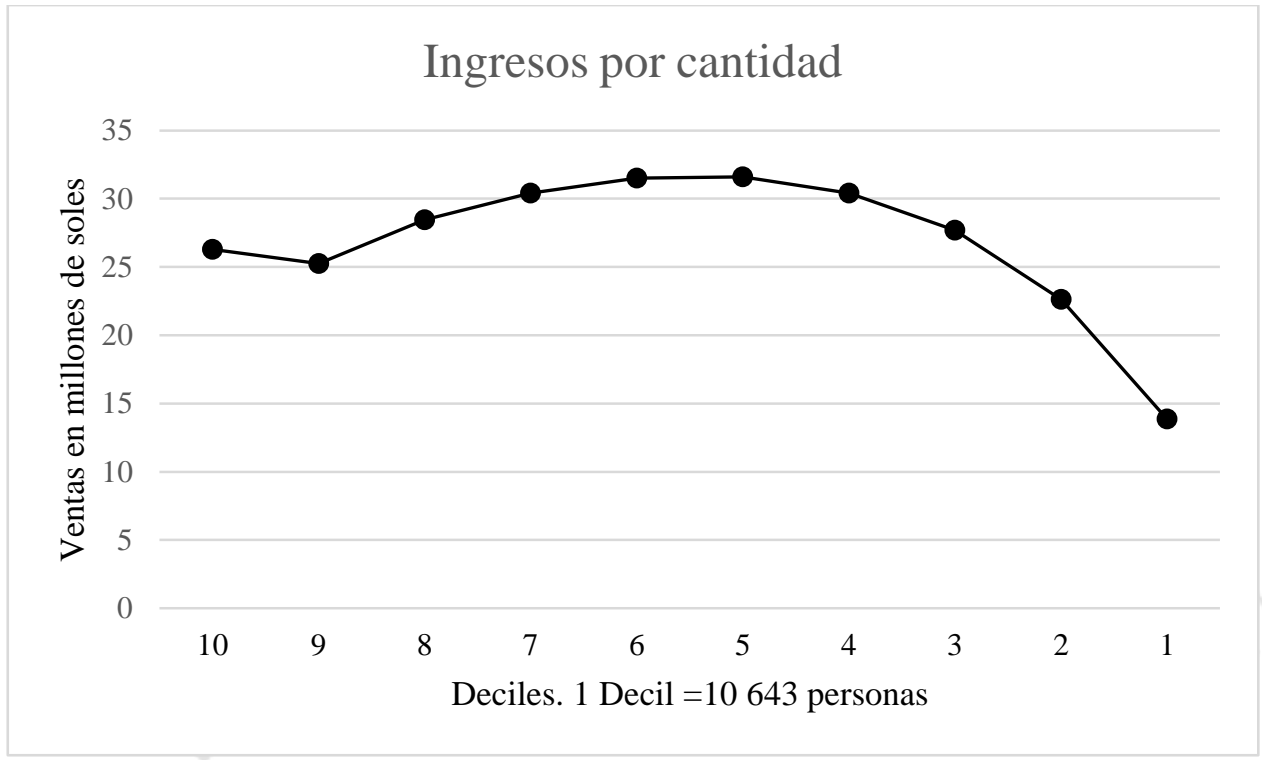

Elaboración propia.

Por otro lado, gracias a que el Ministerio de Salud asume el tratamiento del VIH desde el 2002, el costo del tratamiento antirretroviral de primera línea se redujo a 155 dólares anuales en promedio (Republica, 2015). Ahora bien, no podemos dejar de señalar que en base al análisis realizado el costo del tratamiento subsidiado por el Estado resulta ser igual al Precio de Utilidad Máxima que las empresas deberían fijar para maximizar sus rentas. Existe la posibilidad de que el Estado haya considerado dicho precio para poder maximizar sus ingresos a efectos de tener un menor impacto en la compra de los medicamentos antirretrovirales.

Sin embargo, si el precio subsidiado por el Estado de igual manera excluye al $50 \%$ de la población como se puede apreciar de la Tabla 5, cabe preguntarse ¿Cómo accede al tratamiento el resto de la población? El otro 50\% de la población que no cuenta con los recursos económicos para acceder a un tratamiento, recibe ayuda por las ONGs, fundaciones y otras organizaciones de lucha contra el VIH/SIDA que participan activamente en nuestra sociedad y representan la primera línea de ayuda para los pacientes con VIH. 
Por último, considerando que en el Perú se invierten cerca de S/ 200 millones anuales para cubrir el tratamiento del VIH en los hospitales a nivel nacional según el Ministerio de Salud y de esta inversión, S/ 38 millones son destinados para la compra de antirretrovirales (Redacción, 2014) podemos concluir el gobierno únicamente subsidia el 6 millones y medio de los medicamentos ya que el monto restante es cubierto por los pagos de los pacientes que pueden costear el tratamiento. En caso se aplique una licencia obligatoria para los medicamentos antirretrovirales como el Atazanavir existe una posibilidad que el Estado pueda lucrar con dicho medicamento si se establece un precio muy bajo para dicho medicamento.

El objetivo de este análisis no es criticar el monto que el Estado invierte en medicamentos para VIH sino mostrar la afectación real del sistema de patentes específicamente en el sector farmacéutico para evaluar si realmente en nuestro país es necesario un mecanismo tan polémico como la licencia obligatoria. 


\section{CAPÍTULO VI: ASPECTOS A TOMAR EN CUENTA PARA LA EMISIÓN DE UNA LICENCIA OBLIGATORIA}

Luego de haber esclarecido el panorama económico de las patentes farmacéuticas en el Perú podemos revisar las consideraciones a tomar en cuenta para la eventual emisión de una licencia obligatoria.

\subsection{Agotamiento de la vía previa.}

La licencia obligatoria por motivos de salud pública es un mecanismo excepcional que debe ser utilizado como último recurso dada la naturaleza de su uso en virtud de los ADPIC y la Declaración de Doha. Por ello, se debe hacer uso de políticas previas que permitan hacer frente a crisis de salud pública antes de considerar otorgar una licencia de este tipo.

Las políticas de prevención y educación han demostrado ser efectivas en países como Nicaragua y Senegal. Por ejemplo, la distribución gratuita de profilácticos conjuntamente con campañas de educación para generar conciencia en la población sobre los riesgos del SIDA son las principales acciones en políticas de prevención. Otro mecanismo de prevención es la distribución de la pastilla Truvada que reduce la probabilidad hasta en un $90 \%$ de contraer el virus del VIH (Young, 2014).

En julio del año 2000, la Conferencia Internacional sobre el SIDA se celebró en Sudáfrica destacando dos maneras distintas de hacer frente y combatir el SIDA en distintos países. La primera desarrollada por el gobierno de Brasil, consiste en reducir la tasa de mortalidad del SIDA implementado una política de acceso gratuito a toda la población de medicamentos para la lucha contra el VIH/SIDA (Kripakuri, 2002). La segunda enfocada en reducir la transmisión del VIH fue desarrollada en Uganda. El entonces presidente Museveni y su gobierno lograron reducir la tasa de infección en un 
$15 \%$ logrando los mejores resultados en la población entre quince a diecinueve años de edad entre 1991 y 1998. El modus operandi del gobierno de Uganda era educar a la gente y reducir los comportamientos sexuales de riesgo, así como otorgar paquetes de cuidado de salud y pruebas gratuitas de detección de VIH.

A pesar de la grave situación económica de Uganda, el éxito contra la lucha contra el SIDA ha sido contundente (Guerin) sin siquiera considerar el uso de una licencia obligatoria a pesar de los altos precios existentes en la región (Sackur). Este tipo de política conlleva a una inversión mucho menor que las de reducción de mortalidad, además tiene la ventaja de ser no intervencionista. Sin embargo, en una cultura como la nuestra que exige una "solución rápida" para todo, el uso de las licencias obligatorias para corregir cualquier tema de salud pública no resultaría sorprendente.

El descuido del gobierno por una política imperfecta contra una situación de salud pública no debe afectar a los privados, más aún cuando éstos contribuyen al bienestar social. La implementación de una política de salud acertada es lo menos que podemos esperar de nuestro gobierno. Ahora bien, como hemos señalado anteriormente, la licencia obligatoria por motivos de salud pública es una situación excepcional que sólo es justificable si no hemos logrado un resultado aceptable mediante otros mecanismos como por ejemplo, una implementación de un sistema de salud integral: campañas de concientización, charlas educacionales, campañas de detección temprana del SIDA, mecanismos de prevención entre otros.

En caso el Estado no haya implementado ello de manera integral, tenemos que hacernos la pregunta: ¿El Estado puede perjudicar a los privados por sus propios errores? ¿Podemos otorgar una licencia obligatoria cuando el Estado ha adoptado una estrategia con serios defectos para combatir el VIH? Ciertamente no, la (Dirección de Epidemiologia del MINSA, 2013) ha señalado que "en la lucha contra la epidemia del VIH persisten algunos problemas a nivel operativo, así como factores sociales y estructurales que es necesario sean abordados de manera multisectorial si se tiene por objetivo controlar la propagación del VIH en la población" En este sentido, a la fecha siguen existiendo serias fallas en la política de salud que no demuestran un esfuerzo 
profesional eficiente para combatir el VIH/SIDA.

Si bien estas deficiencias se han superado parcialmente con el nuevo "Plan Estratégico Multisectorial de Prevención y Control de ITS, VIH y SIDA 2015-2019»"46 que incluye una planificación para afrontar el SIDA en el país dando énfasis a la estrategia de mejorar la promoción y difusión de medidas de prevención contra las ITS y el VIH/SIDA fortaleciendo una Educación Sexual Integral con énfasis en estigma y discriminación, existen frentes para afrontar el VIH que tienen la potencialidad de mejorar ampliamente tal como la compra de medicamentos, igualdad de género entre otros.

\subsubsection{Compra y distribución de medicamentos.}

La mala gestión en la compra de fármacos por parte del Estado ya ha copado las primeras planas de los diarios a nivel nacional. La Gerencia Central de Prestaciones Económicas y Sociales de EsSalud encontró pacientes a quienes supuestamente se les entregaron excesivas cantidades de medicamentos sin clara justificación (dosis por encima de lo que su peso e historia clínica indican) en perjuicio de los demás enfermos (Torres, 2013).

Por otro lado, nos preguntamos la razón por la cual el Estado no implementa compras corporativas o importaciones paralelas. Mediante Resolución Ministerial $\mathrm{N}^{\circ}$ 012-2014/MINSA se excluyó al Atazanavir entre otros medicamentos de las compras corporativas del Estado arguyendo razones sin sustento alguno. Los antirretrovirales que compra el Estado se realizan a través de compras institucionales como se puede apreciar del cuadro siguiente:

${ }^{46}$ Aprobado mediante Decreto Supremo 035-2015-SA. 
Tabla 6. Compras realizadas por el Perú.

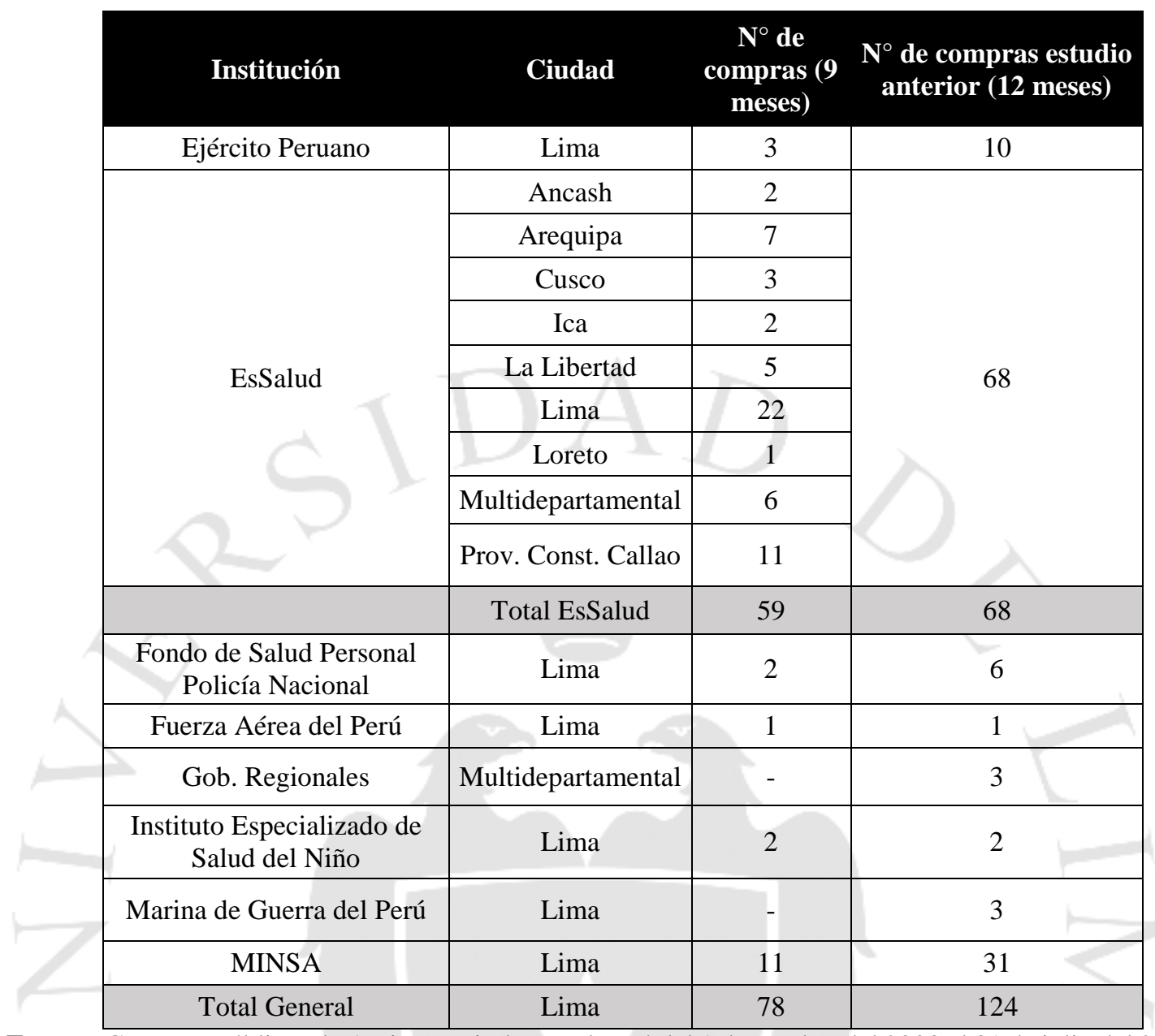

Fuente: Compras Públicas de Antirretrovirales en el Perú del 1 de octubre del 2008 al 31 de julio del 2009. AIS LAC Serie Investigaciones y Monografías N²9/2010.

Las compras institucionales resultan más caras en comparación con las compras corporativas que son mucho más eficientes debido a la cantidad y el poder de negociación. Por otro lado, el Perú se encuentra habilitado para realizar importaciones paralelas, el cual es un mecanismo válido a efectos de obtener un mejor precio dado en otro país, y puede utilizarse como amenaza para negociar con los laboratorios farmacéuticos.

\subsubsection{Patent pools.}

En diciembre de 2013 el Medicine Patent Pool y la empresa Bristol- Myers Squibb firmaron un acuerdo de licencia voluntaria para aumentar el acceso al Atazanavir en 110 países en desarrollo, por el cual fabricantes de varios países producen versiones más asequibles de Atazanavir, el acuerdo también permite combinar este medicamento con 
otros para facilitar y hacer más accesible el tratamiento en los países en desarrollo. Así, se proporciona a los titulares de sub licencias un paquete de transferencia de tecnología para facilitar la producción de Atazanavir.

Sin embargo, el Perú es uno de los países que no ha sido incluido en el referido acuerdo, a pesar de los requerimientos formulados por el Ministerio de Salud para formar parte del mismo. La suscripción de este acuerdo es un paso importante para un mayor acceso a los medicamentos sin afectar derechos de propiedad intelectual, y de ser necesario el gobierno en conjunto y no solo el Ministerio de Salud tiene la obligación de solicitar apoyo internacional para hacer frente a esta situación.

\subsubsection{Igualdad de género.}

Un aspecto que se encuentra relacionado indirectamente a la incidencia de VIH en la población es la educación sexual y la información que se brinda sobre esta enfermedad. Sin embargo, existen cuestiones culturales que todavía es un tabú en nuestra sociedad como la igualdad de género. Las normas sociales de género relacionadas con los papeles, las expectativas y las conductas "femeninas" y "masculinas" influyen enormemente en el acceso de hombres y mujeres a la información y los servicios asociados al VIH, así como en sus actitudes y su conducta sexual, además del modo en que afrontan las situaciones en caso de que ellos mismos o un familiar vivan con VIH. La subordinación en los matrimonios o relaciones, en los que, a menudo, se espera de las mujeres que sean pasivas e ignorantes de las prácticas sexuales, menoscaba en gran medida su capacidad para negociar el uso del condón para garantizarse un sexo más seguro, o para rechazar las relaciones sexuales inseguras. Se ha observado que la violencia ejercida contra mujeres y niñas, o la amenaza de la misma, elevan el riesgo de infección por VIH al tener relaciones sin protección (Cruz, 2011).

Según la experta en VIH e igualdad de género, (Cruz, 2011) los varones y los niños son víctimas de las expectativas sociales para demostrar su "masculinidad", lo que puede elevar su tendencia a mantener conductas de alto riesgo, como las asociadas a unas tasas elevadas de alcoholismo y toxicomanía, así como al mantenimiento de relaciones sexuales con parejas ocasionales o múltiples. En muchos países, los servicios 
relacionados con el VIH y el SIDA se prestan fundamentalmente en las clínicas de planificación familiar, prenatales y de salud infantil, diseñadas habitualmente para ofrecer servicios basados en el supuesto de que sólo las mujeres tienen responsabilidades en materia de salud reproductiva. La dependencia económica respecto al varón reduce la capacidad de las mujeres para negociar la práctica de un sexo más seguro y, con frecuencia, les impide pagar servicios de salud como la realización de las pruebas del $\mathrm{VIH}$, o procurarse tratamiento.

La desigualdad por razón de género y el VIH/SIDA se encuentran inextricablemente unidos. La Conferencia Internacional del Trabajo (CIT) de junio de 2009, en su Resolución relativa a la igualdad de género en el corazón del trabajo decente subraya la importancia de promover la igualdad de género y la respuesta a las dimensiones del VIH y el SIDA relacionadas con el género.

Lo expuesto demuestra que hay caminos alternativos y mejoras a lograr que tenemos que realizar antes de pensar en el otorgamiento de una licencia obligatoria que no pueden ser dejados de lado por el simple hecho de obtener una solución rápida para el Estado con carga en los particulares. Los privados no tenemos la obligación de pagar los platos rotos del Estado.

\subsection{Situaciones de emergencia nacional o interés público.}

El artículo 65 de la Decisión 486 de la Comunidad Andina señala que una licencia obligatoria sólo podrá emitirse previa declaratoria de un País Miembro de la existencia de razones de interés público, de emergencia, o de seguridad nacional y sólo mientras estas razones permanezcan.

Para que se configure el interés público o de emergencia se deberá emitir dicha declaratoria mediante decreto supremo según lo previsto por el artículo 40 del Decreto Legislativo $\mathrm{N}^{\circ}$ 1075. Como estamos hablando de circunstancias excepcionales que servirán de excusa para limitar los referidos derechos, las razones deberán ser reconocidas 
a través de una norma, y no solo declaradas o expuestas, sino también amplia y claramente sustentadas en cada caso en concreto. La misma naturaleza del Decreto Supremo exige que no sea suficiente una difusa mención de la existencia de un interés público o urgencia nacional, sino que éste debe ser probado con hechos graves concretos que pongan de manifiesto el peligro en el que se encuentra el interés general de la población. Para que el "interés público", "emergencia" o "seguridad nacional" configure una causal que justifique el otorgamiento de una licencia obligatoria de una patente no bastará la sola mención o declaración de esta situación sino que se requiere el señalamiento explícito, concreto y claro de las razones, hechos, motivaciones o circunstancias que la justifican. ${ }^{47}$

A continuación desarrollaremos únicamente la definición de "interés público" y "emergencia" debido a que son conceptos ligados a la imposición de una licencia obligatoria por salud pública.

\subsubsection{Definición de interés nacional.}

Uno de los puntos más controvertidos en esta discusión es el concepto de interés público: la forma en que se determina y define. La conceptualización del interés público en cada caso concreto justifica y sustenta el poder de resolución unilateral de que goza el Estado y constituye un límite a la arbitrariedad. En ese sentido, sirve para justificar diversas formas de intervención del Estado en la esfera de los particulares previendo límites de distinto grado, ya sea a través de prohibiciones, permisos o estableciendo modos de gestión.

En el caso particular de la licencia obligatoria, el artículo 40 del Decreto Legislativo $\mathrm{N}^{\circ} 1075$ asimila las razones de interés público, de emergencia o de seguridad nacional dentro de los supuestos de "emergencia nacional u otras circunstancias de extrema urgencia" como causales habilitantes para el otorgamiento de este tipo de

\footnotetext{
${ }^{47}$ Es así que el interés público, como concepto indeterminado, se construye sobre la base de la motivación de las decisiones, como requisito sine qua non de la potestad discrecional de la Administración, quedando excluida toda posibilidad de arbitrariedad. Sentencia del Tribunal Constitucional recaída en el Expediente 0090-2004-AA/TC.
} 
licencia, lo que significa que toda razón de interés público debería reunir los atributos para ser considerada una circunstancia de extrema urgencia. Esta interpretación permite justificar y sustentar las medidas de emergencia o seguridad nacional bajo los mismos parámetros que el interés público.

La justificación del interés público no puede quedar enteramente al designio o voluntad discrecional de un órgano político o de un funcionario público debido a que puede configurarse abusos sobre el uso de la licencia obligatoria tal como sucedió en India. Tal como lo señala Astudillo Gómez, "el interés público abarca un abanico de circunstancias que pueden ir desde la solución de algún problema económico particular hasta el tratamiento de situaciones de orden político, razón por la cual esta causal de licencia obligatoria se presta a un margen de discrecionalidad excesivamente amplio conviene acotarlas en las leyes" (Astudillo, 2012) o en lineamientos que doten de un contenido a dicho concepto.

Es por ello que a continuación trataremos de conceptualizar el interés público. En primer lugar, conviene revisar lo señalado por el Tribunal Constitucional en la sentencia recaída en el expediente 2488-2004-AA/TC:

El interés público, es típicamente un concepto indeterminado. Es decir, se trata de un concepto que hace referencia a una esfera de la realidad cuyos límites no aparecen precisados en su enunciado, pero que sin embargo podrá ser concretizado en cada caso en atención a las circunstancias.

Así, no se trata de un concepto librado enteramente a la discrecionalidad de la Administración, pues ello supondría en muchos casos justificar la arbitrariedad, sino que se trata de un concepto cuyo contenido deberá ser explicado en cada caso en atención a circunstancias concretas.

De este modo, si bien el Tribunal Constitucional señala que el interés público debe ser analizado caso por caso, éste no es un concepto enteramente librado a la 
discrecionalidad. En este sentido, dar una definición puede impedir el uso eficiente de las licencias obligatorias. Sin embargo, aclarar estas ambigüedades no sólo mejorará la eficiencia en la utilización de las licencias obligatorias, no obstante también puede alentar a los países a emitir licencias obligatorias sin preocupaciones de reacción política.

Por ello, es necesario brindar los lineamientos necesarios y no una definición como bien ha advertido el Tribunal Constitucional con el objetivo de justificar el interés público en cada caso en particular.

Siendo que en estos casos existe una colisión de derechos constitucionales por una parte el derecho a la libre iniciativa privada ${ }^{48}$ y propiedad y por otro lado el derecho a la salud, ${ }^{49}$ seguridad o algún otro correspondiente al interés nacional invocado deben ser analizados a la luz de la teoría de la ponderación o proporcionalidad desarrollada por (Alexy, 2009).

Siguiendo la línea de Alexy, se puede afirmar que el principio de proporcionalidad exige examinar la colisión a la luz de los juicios, máximas o sub-principios de adecuación o idoneidad, necesidad y proporcionalidad en sentido estricto (Burga, 2011). (Bernal Pulido, 2003) los desarrolla de la siguiente manera: El de adecuación o idoneidad: Según este sub-principio, toda intervención en los derechos fundamentales debe ser adecuada para contribuir a la obtención de un fin constitucionalmente legítimo.

(ii) El de necesidad: Según este sub-principio, toda medida de intervención en los derechos fundamentales debe ser la más benigna con el derecho

\footnotetext{
${ }^{48}$ Mediante la STC 0008-2003-AI/TC, se recordó que en virtud del principio de libre iniciativa privada, "toda persona natural o jurídica tiene derecho a emprender y desarrollar, con autonomía plena, la actividad económica de su preferencia, afectando o destinando bienes de cualquier tipo a la producción y al intercambio económico con la finalidad de obtener un beneficio o ganancia material".

${ }^{49} \mathrm{El}$ derecho a la salud constituye un derecho constitucional. Conforme al artículo 7 de la Constitución, "Todos tienen derecho a la protección de su salud, la del medio familiar y la de la comunidad (...), así como el deber de contribuir a su promoción y defensa. (...)”. El contenido o ámbito de protección de este derecho constitucional consiste en la "facultad inherente a todo ser humano de conservar un estado de normalidad orgánica funcional, tanto física como psíquica, así como de restituirlo ante una situación de perturbación del mismo". (STC 1429-2002-HC/TC, FJ 12, segundo párrafo).
} 
constitucional intervenido, entre todas aquellas que revisten por lo menos la misma idoneidad para alcanzar el objetivo propuesto.

(iii) El de proporcionalidad en sentido estricto: Según este sub-principio, la importancia de la intervención del derecho fundamental debe estar justificada por la importancia del fin perseguido por la intervención legislativa.

Si realizamos el análisis anterior, ${ }^{50}$ respecto del sub-principio de adecuación nos encontramos ante la interrogante de cuál es la forma más idónea o adecuada para salvaguardar el derecho de salud de la población.

Como bien señala el Ministerio de Justicia en su Informe "La Constitucionalidad de la Declaratoria de Interés Público del Acceso al Medicamento Atazanavir" ${ }^{\text {51 }}$, el bien jurídico tutelado es el derecho a la salud, específicamente de la población con VIH/SIDA. En cuanto al derecho a la salud, el Tribunal ha señalado que la Constitución "reconoce el derecho de la persona de alcanzar y preservar un estado de plenitud física y psíquica. Por ende tiene el derecho de que se le asignen medidas sanitarias y sociales relativas a la alimentación, vestido, vivienda y asistencia médica (...) Por ende, los servicios público de salud cobran vital importancia (...) pues de ellos no solo depende el logro de mejores de las personas, sino que incluso en la eficiencia de su prestación está en juego la vida y la seguridad de los pacientes.

En ese sentido, el Informe "La Constitucionalidad de la Declaratoria de Interés Público del Acceso al Medicamento Atazanavir" señala que hay situaciones que, dada su gravedad y riesgo cierto al derecho fundamental a la salud, obliga al Estado a adoptar medidas urgentes para evitar un grave e irreversible daño a la salud, e incluso a la vida. Ello se encuentra debidamente sustentado por el Tribunal Constitucional que establece lo

\footnotetext{
${ }^{50}$ Este test es recogido por la metodología para el análisis de racionalidad de barreras burocráticas desarrollado por el precedente de observancia obligatoria sancionado por el Tribunal del INDECOPI mediante (Resolución 182-1997/TDC, 1997)

${ }^{51}$ Informe enviado al Viceministerio de Justicia para respaldar la Exposición de Motivos del Decreto Supremo que busca declarar interés público la licencia obligatoria contra el medicamento Atazanavir mediante Nota $\mathrm{N}^{\circ}$ 001-2015-JUS/DGDH-DAIPAN del 1 de julio del 2015.
} 
siguiente:

"Cuando la salud queda severamente afectada y la propia existencia se pone el riesgo, ante el impedimento de acceder a los servicios de salud, el Estado adquiere mayores exigencias, que van desde la existencia de planes específicos y urgentes que afronten esta situación hasta la exigibilidad directa, en ciertos casos, del derecho a la salud.

Únicamente mediante un tratamiento adecuado y continuo pueden reducirse las manifestaciones no solo físicas, sino psicológicas de la enfermedad, logrando que en muchos casos el normal desenvolvimiento de las actividades del paciente no se vea afectado en un lapso mayor que en aquellos casos donde la asistencia médica es casi nula. Es en este último caso donde la dignidad, la libertad y la autonomía de la persona se ven afectadas a consecuencia del deterioro de la salud y riesgo de vida del paciente, tornando a estos individuos en una suerte de parias sociales, lo que de ninguna manera puede ser admitido desde el punto de vista constitucional” (STC 2945-2003-AA/TC, 2012).

Asimismo, el artículo 7.2 de la Ley $\mathrm{N}^{\circ} 28243$, que declara la necesidad e interés público la lucha contra la infección por el VIH y el SIDA y las Enfermedades de Transmisión Sexual, refiere que toda persona que se encuentra viviendo con VIH y SIDA, tiene derecho a recibir atención integral de salud continua y permanente por parte del Estado, a través de todos los establecimientos de salud donde tenga administración, gestión o participación directa o indirecta y a la prestación previsional que el caso requiera. El suministro de medicamentos requeridos para el tratamiento adecuado e integral de la infección por el VIH y SIDA que en el momento se consideren eficaces para prolongar y mejorar la calidad de vida de las PVVS (pacientes), estableciendo la gratuidad progresiva en el tratamiento antirretroviral con prioridad en las personas de vulnerabilidad y pobreza extrema.

A modo de conclusión, el informe citado anteriormente señala que la potestad de 
declarar interés público el acceso al medicamento Atazanavir está indefectiblemente ligado a la efectiva consecución de un interés que está directamente vinculado a una finalidad fundamental del Estado Social y democrático de Derecho, el cual es garantizar el derecho fundamental a la salud, y concretamente la accesibilidad a los medicamentos en casos de graves enfermedades como el VIH/SIDA. ${ }^{52}$

Ahora bien, los argumentos señalados anteriormente son los utilizados para sustentar las siguientes iniciativas para declarar interés público el medicamento Atazanavir: (i) Proyecto de Ley 275-2016/CR que declara de interés público el medicamento Atazanavir presentado por el congresista Hernando Cevallos Flores del grupo Parlamentario Frente Amplio; y, (ii) el Proyecto de Ley 4484-2014/CR que declara de necesidad, utilidad pública y preferente interés social facilitar el alcance al público de medicamentos para tratar enfermedades incurables presentado por el ex congresista Leonidas Huayama Neira del grupo parlamentario Gana Perú Incluso, el Proyecto de Decreto Supremo del Ministerio de Salud ${ }^{53}$ que todavía no ha sido publicado utiliza dichos argumentos para sustentar la emisión de la licencia obligatoria contra el medicamento Atazanavir.

No queda duda de que el Estado tiene la obligación de cautelar el derecho a la salud e integridad de las personas, en especial de las poblaciones más vulnerables como los pacientes con VIH/SIDA, sin embargo, ello tiene que realizarse con las medidas adecuadas destinadas a lograr el fin señalado. La medida no solo debe tener alguna relación lógica con el objetivo previsto, sino que además debe ser "eficaz". Una medida que es inherentemente incapaz de alcanzar el objetivo determinado, o que es manifiestamente ineficaz en el alcanzarlo, no puede decirse que es "idónea", "necesaria" o "proporcional".

En primer lugar, cabe preguntarnos si las personas con VIH/SIDA tienen acceso a un tratamiento que garantice un nivel de vida adecuado. Si la respuesta fuera negativa,

\footnotetext{
52 Informe "La Constitucionalidad de la Declaratoria de Interés Público del Acceso al Medicamento Atazanavir" Pág. 16.

${ }^{53}$ Documento no publicado al 21 de mayo del 2017. Ver Anexo 3.
} 
pasamos a cuestionarnos si la falta de acceso a un tratamiento corresponde a los altos precios de medicamentos. Lo primera pregunta nos ayuda a determinar si el problema existe de verdad y la segunda si dicho problema corresponde a una causa determinada.

Respecto de la primera pregunta, cabe señalar que las personas con VIH/SIDA sí cuentan con acceso a un tratamiento. Como lo señala el Ministerio de Salud, el financiamiento de las intervenciones de prevención, diagnóstico, tratamiento y seguimiento de las personas con infección por VIH/SIDA se encuentran cubiertas según lo estipulado en el Plan Esencial de Aseguramiento en Salud, el mismo que establece que el tratamiento antirretroviral de gran actividad "TARGA" se encuentra garantizado y es totalmente gratuito para pacientes con VIH/SIDA.

En efecto, en su Análisis de la Situación Epidemiológica del VIH/SIDA en el Perú para el 2013 (Dirección de Epidemiologia del MINSA, 2013), el Ministerio de Salud señaló que la implementación del programa de Tratamiento Antirretroviral de Gran Actividad (TARGA) es definitivamente uno de los principales logros alcanzados por el Perú en la lucha contra el VIH, y agrega que en el último Informe de Progreso de la Declaración Política sobre VIH/SIDA del 2011 (UNGASS) el Perú reportó que el 92.7\% de personas con VIH que necesitaban el tratamiento y que accedieron al sistema de salud, se encontraban recibiendo el TARGA.

De hecho, la mortalidad ha decrecido considerablemente gracias al tratamiento gratuito TARGA otorgado por el Estado. En el gráfico siguiente se puede apreciar como inmediatamente se redujo las defunciones reportadas gracias a la implementación del programa gratuito TARGA. Cabe indicar que dicha cifra se encuentra reportada hasta el año 2011, por lo que considerando la curva descendente de la Figura 8, al día de hoy la tasa de mortalidad del VIH/SIDA debería ser menor. 
Figura 8. Número de defunciones 2000-2011.

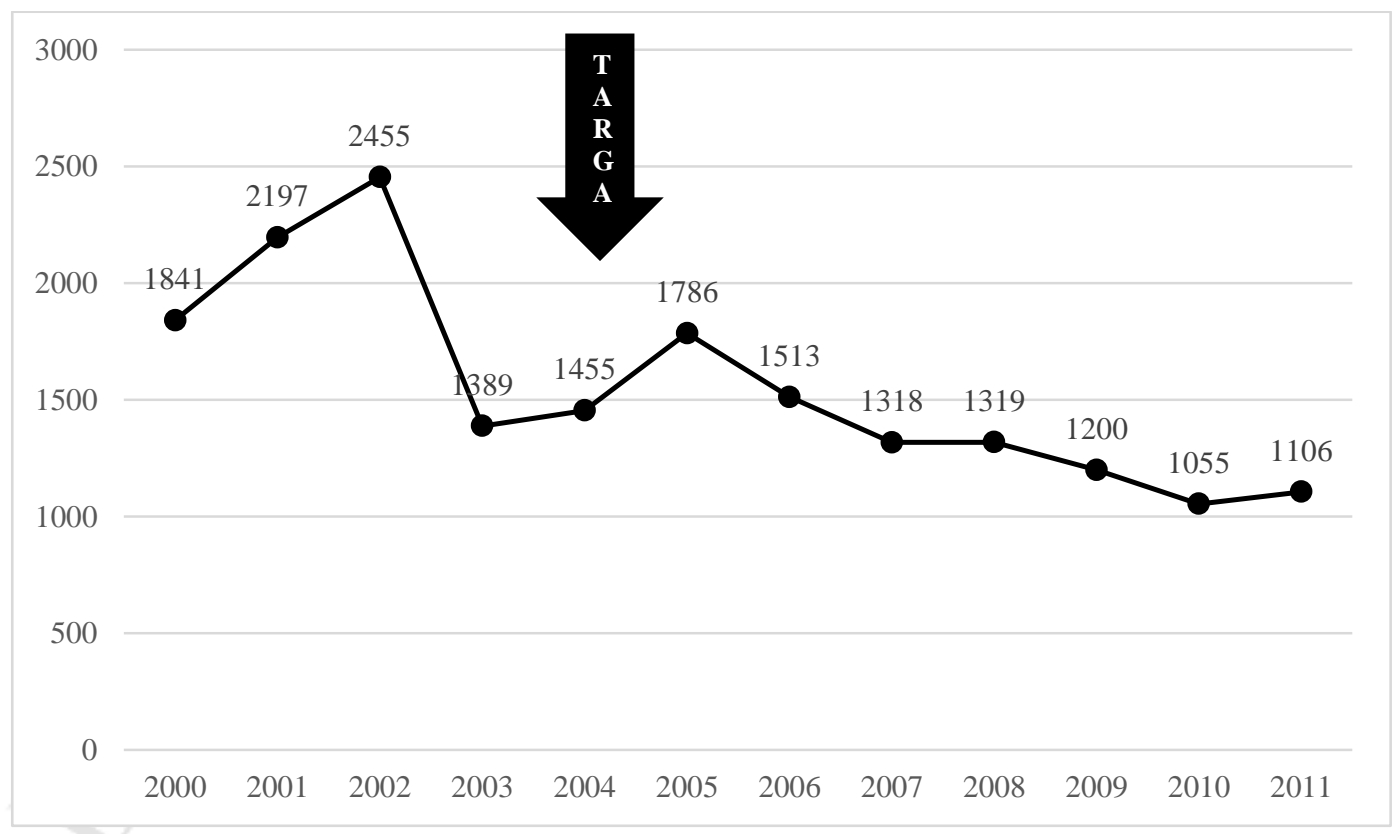

Fuente: NOTI-VIH/RENACE. Grupo Temático de TB-VIH/SIDA. Dirección General de Epidemiología - MINSA. Elaborado por Dra. Mónica Pun.

En el propio informe del Ministerio de Salud se reconoce que en la implementación del Plan Estratégico Multisectorial para la Prevención y Control de las ITS-VIH/SIDA en el Perú, se observaron algunas deficiencias, aunque la mayoría relacionadas con la calidad de atención en los servicios de salud, pero no de provisión o acceso a esta droga.

Entonces cabe preguntarnos la razón por la cual algunos grupos de interés se encuentran solicitando la emisión de una licencia obligatoria si los pacientes con VIH/SIDA tienen garantizado el acceso gratuito al tratamiento contra el VIH/SIDA. Sea cual sea la razón, lo cierto es que a la fecha la emisión de una licencia obligatoria no va a reducir la tasa de mortalidad del VIH/SIDA ni la incidencia de infecciones de dicha enfermedad.

En caso hubiéramos logrado superar la valla del sub-principio de idoneidad y necesidad, se debe responder a los cuestionamientos del sub-principio de proporcionalidad que por razones académicas lo haremos. En ese sentido, cabe cuestionar si la medida no afecta a otros bienes jurídicos tutelados. De afectar otro bien jurídico, 
como por ejemplo, el derecho a la propiedad, cabe preguntarnos si realmente resulta necesario afectar dicho derecho para lograr el fin buscado.

En este caso en particular, no debemos olvidar que están en juego objetivos de relevancia social que fundamentan el sistema de patentes, tales como la promoción a la innovación, el avance tecnológico, incentivos a la inversión en investigación, desarrollo, ciencia y tecnología, por lo que una política poco rigurosa, flexible o concesiva significaría un atentado directo a estos objetivos, además de una abierta vulneración a derechos fundamentales asociados a la libre creación científica y técnica y a la posibilidad de detentar derechos de Propiedad sobre estos resultados.

Por ende, más allá de quedar claro que el Estado está legalmente legitimado a emplear el mecanismo de las licencias obligatorias (...) hay que destacarse que este instituto, sin embargo, es una excepción al derecho de exclusividad conferido por la patente. De esta forma, como todas las excepciones, esta herramienta deberá ser utilizada solamente en los casos previstos en los instrumentos jurídicos ya mencionados, para que éste no sea un aparato empleado por el Estado en cualquier circunstancia. El empleo desmedido de este instrumento, podría configurar un abuso al derecho del propietario sobre la invención patentada, cuando no estén configuradas las situaciones ya descritas (Klein, 2011).

Por los argumentos expuestos, no corresponde declarar de interés público el medicamento Atazanavir o algún otro en la lucha contra el VIH/SIDA para la consecuente emisión de una licencia obligatoria ya que existen caminos adicionales que debemos tomar antes de una licencia obligatoria de este tipo.

\subsubsection{Definición de emergencia nacional.}

La legislación aplicable de la mayoría de los Estados miembros que prevé la concesión de licencias obligatorias por razones de "emergencia nacional" o "circunstancias de extrema urgencia" no establece una definición de tales circunstancias. En algunos Estados miembros se definen las emergencias nacionales mediante la enumeración de 
ejemplos, tales como "seguridad de estado, protección del interés público en el campo de la salud y la nutrición, protección y mejora del entorno humano o interés especial en una determinada rama de la economía, guerra, sublevación u otra emergencia similar", “desastres, catástrofes o accidentes graves", "defensa nacional, emergencia o bien público no comercial”, o "seguridad nacional, protección del interés público en el campo de la salud, suministro de alimentos, protección y mejora del medio ambiente e interés comercial específico" (OMPI, 2014).

La expresión "situación extrema" se define, en términos generales, como "la interrupción de la vida y la actividad normales de la población (...) en una región como consecuencia de accidentes, desastres, calamidades naturales o socio biológicas que hayan provocado, o que pueden provocar, pérdidas humanas y económicas". ${ }^{4}$ En el cuestionario realizado por la OMPI a algunos países han definido la expresión "urgencia o emergencia" (OMPI, 2014). En Serbia, las circunstancias de una "emergencia nacional" o las "circunstancias de extrema urgencia" se definen como una emergencia pública que supone "una amenaza para la supervivencia del Estado o sus ciudadanos". China, en relación con las emergencias nacionales, mencionó en su respuesta "las guerras y cualquier otra emergencia que ponga en peligro el país, o cualquier desastre natural o enfermedades pandémicas".

Ahora bien, en ciertas ocasiones el Organismo de Solución de Diferencias de la OMC ha acudido a referencias de organización para fundamentar su decisión. En este sentido, en el artículo primero del Reglamento Sanitario Internacional de 2005 adoptado en la $58^{\circ}$ Asamblea Mundial de la Salud de la OMS se establece que las emergencias de salud pública de importancia internacional son aquellas que "i) constituyen un riesgo para la salud pública de otros Estados a causa de la propagación internacional de una enfermedad, y ii) podría exigir una respuesta internacional coordinada”.

Sin embargo, dicha definición únicamente hace referencia a aquellas situaciones de importancia internacional sin hacer referencia al ámbito nacional. Por ello, otro criterio

\footnotetext{
${ }^{54}$ Artículo 1.2) de la Ley 93/2007 del Servicio de Protección Civil y las Situaciones Extremas de la República de Moldova.
} 
que se podría utilizar es el concepto de urgencia que maneja la Corte Internacional de Justicia al conceder medidas provisionales. ${ }^{55}$ Dichas medidas tienen como objeto preservar los derechos de cualquiera de las partes mientras queda pendiente una decisión de la Corte para evitar que se cause un perjuicio irreparable a los derechos objeto de disputa en el procedimiento judicial.

Una clara situación de emergencia nacional de acuerdo a las definiciones dadas por los países consultados por la OMPI es la de Sudáfrica. Según la BBC (Barrow), 20\% de los adultos sudafricanos son enfermos de SIDA. Asimismo, 250.000 sudafricanos murieron de SIDA en 1999. Dichas cifras ha ido en aumento desde el primer caso detectado en el país. La situación en el país africano requería con urgencia acciones para controlar la pandemia en la población. En este tipo de situaciones, donde a pesar de las estrategias implementadas el estado como tal y su población se encontraba en riesgo no cabe duda que la mejor solución es la imposición de una licencia obligatoria.

Dicha situación no se presenta en nuestro país, más aún si la tasa de mortalidad se reduce año a año y los casos reportados han disminuido considerablemente. Es por ello, que considero que la situación en nuestro país del VIH/SIDA se encuentra debidamente controlada y no representa una urgencia extrema.

\subsubsection{Procedimiento de declaratoria del "interés público" o "urgencia extrema".}

A pesar que considero que la situación del VIH/SIDA en nuestro país no puede ser considerada de circunstancias extremas o de interés nacional por lo señalado en los acápites anteriores, es necesario que caso se suscite una situación de este tipo se emita una licencia obligatoria de manera inmediatamente. Actualmente, existe un vacío en nuestra legislación respecto del procedimiento de declaratoria de interés público o

\footnotetext{
55 El mecanismo de medidas cautelares tiene como propósito asegurar una respuesta rápida de la CIDH ante situaciones graves y urgentes de riesgo inminente que pueden producir daños irreparables para las personas o grupos de personas en los 35 Estados Miembros de la OEA. Es un mecanismo utilizado por todos los organismos globales y regionales de derechos humanos, con base en criterios similares (OEA, 2012).
} 
urgencia que resulta perjudicial para nuestra sociedad, en la medida que las partes perjudicadas o los ciudadanos no tienen un procedimiento establecido que contemple requisitos y plazos para presentar la solicitud de declaración de interés público en aras de lograr una licencia obligatoria.

La falta de un instrumento de este tipo genera que el poder ejecutivo pueda poner trabas a la declaratoria para la imposición de una licencia obligatoria en caso la situación lo amerite. Por ello, a me he tomado la libertad de adecuar el procedimiento dado en Colombia para la adopción de un procedimiento de declaratoria de la existencia de razones de interés público en el Anexo 1.

\subsection{Regalías.}

Otro punto a tomar en cuenta al momento de emitir una licencia obligatoria corresponde a la compensación económica. El literal h) del artículo 31 de los ADPIC señala que en casos de licencias obligatorias, el titular de los derechos recibirá una remuneración adecuada según las circunstancias propias de cada caso, habida cuenta del valor económico de la autorización.

De la misma manera, el artículo 65 de la Decisión 486 y el Decreto Legislativo $\mathrm{N}^{\circ} 1075$ establece que para las licencias obligatorias por razones de emergencia o de interés público la oficina nacional competente, en este caso el INDECOPI, establecerá el alcance o extensión de la licencia obligatoria, especificando en particular, el período por el cual se concede, el objeto de la licencia, el monto y las condiciones de la compensación económica. En líneas generales, los gobiernos tienen un margen considerable para definir el nivel y tipo de remuneración que el titular de la patente debe recibir. La regla general es que la remuneración debe ser adecuada, teniendo en cuenta las circunstancias de cada caso y el valor económico de la licencia obligatoria.

Ahora bien, el Proyecto de Lineamientos para el procedimiento de emisión de Licencias obligatorias publicado mediante Resolución de Presidencia del Consejo Directivo $\mathrm{N}^{\circ}$ 059-2015-INDECOPI/COD señala que luego de correr traslado de la 
solicitud de licencia obligatoria al titular de la patente, evaluará con apoyo de la Gerencia de Estudios Económicos la compensación económica que corresponde al titular. Sin embargo, el Proyecto de Directiva no incluye lineamiento alguno que permita esclarecer la cuantía de las regalías por el uso de la patente a pesar que en los últimos años se han adoptado o propuesto una serie de sistemas de regalías, y se han establecido marcos útiles para su examen.

Los lineamientos para determinar regalías reducirán la complejidad de su determinación, así como aumentarán la transparencia y la previsibilidad. Los modelos de regalías pueden estar basados en distintos preceptos tal como: capacidad administrativa, limitaciones de recursos, la sensibilidad a las normas, apoyo a la I + D y objetivos de política en materia de acceso e innovación. ${ }^{56}$

A continuación un resumen de los lineamientos más importantes que han sido utilizados para calcular una adecuada compensación económica:

- La Oficina de Patentes de Japón 1998 (JPO) (Directrices para las patentes de medicamentos) especifica las regalías entre un $2 \%$ - 4\% del precio del producto genérico; esta cantidad puede ser aumentada o disminuida por tanto como $2 \%$, para un rango de $0 \%-6 \%$.

- El Programa de las Naciones Unidas de 2001 (PNUD) propone una tasa de regalía base del $4 \%$ del precio del medicamento genérico. Esto puede ser aumentado o disminuido en un $2 \%$, para un rango de $2 \%$ a $6 \%$, dependiendo de diversos factores (grado de innovación de la medicina, o el papel de los gobiernos en el pago de la investigación y desarrollo).

- De acuerdo con la Decisión de la OMC de 30 de agosto de 2003, en el 2005 el gobierno de Canadá establece las directrices de regalías por licencias obligatorias

\footnotetext{
${ }^{56}$ Para los países capaces y dispuestos a realizar determinaciones algo más complejas de las regalías, se debería evaluar una serie de factores apropiados, estos incluyen pero no se limitan a: (i) valor terapéutico del medicamento; (ii) la capacidad del público para pagar el medicamento; (iii) gastos reales y documentados sobre el desarrollo del medicamento; (iv) la medida en que la invención se benefició de la investigación financiada con fondos públicos; (v) la necesidad de responder a las exigencias de salud pública; (vi) la importancia de la invención patentada para el producto final; los ingresos globales acumulados y la rentabilidad de la invención; entre otros. (Organización Mundial de la Salud, 2005)
} 
de patentes a los países que carecen de la capacidad para fabricar medicamentos. La tasa de regalías (entre el $0,02 \%$ y el $4 \%$ del precio de un medicamento genérico) es determinado por el rango del país en el Índice de Desarrollo Humano de la ONU. Para la mayoría de los países en desarrollo, la tasa de regalías es inferior al 3\%. Para la mayoría de los países de África, la tasa es inferior al $1 \%$.

En resumen, hay una amplia variación en la forma en que las agencias gubernamentales responsables y los tribunales han establecido el monto de la remuneración otorgada a los titulares de patentes cuando éstas han sido sometidas a licencia obligatoria. El Reino Unido ha proporcionado la remuneración más generosa en sus decisiones de concesión de licencias de patentes de medicamentos; y Estados Unidos ha contemplado regalías mínimas para los casos antimonopolio.

Por ejemplo, en el caso de la licencia obligatoria emitida por el gobierno ecuatoriano para el Ritonavir, la autoridad competente tomó en consideración el Método a Gradas de Regalías, en adelante TRM por su siglas en inglés, señalando que las regalías son independientes del costo de manufactura y varían directamente de los sustitutos de valor terapéutico y la capacidad de pago. El TRM provee regalías mucho más altas para países de ingreso mediano y alto con cargas bajas de la enfermedad y las regalías más bajas para países que tienen ingresos más bajos y las tasas más altas de la carga de la enfermedad. En el caso específico del Ritonavir se realizó el siguiente cálculo:

Tabla 7. Regalías Ritonavir.

\begin{tabular}{|l|l|}
\hline \multicolumn{1}{|c|}{ Factor } & \multicolumn{1}{c|}{ Cálculo } \\
\hline Precio EE.UU. por frasco & $\$ 289.99$ \\
\hline Precio EE.UU. por cápsula & $\$ 9.67$ \\
\hline Regalía 5\% & $\$ 0.4835$ por cápsula \\
\hline Ingreso promedio EE.UU. & $\$ 46443.00$ \\
\hline Ingreso promedio Ecuador & $\$ 3939.00$ \\
\hline Proporción ingreso promedio Ecuador a EE.UU & $3939 / 46449=0.084813642$ \\
\hline Regalía a Grada & $\$ 0.4835 \times 0.084813642=\$ 0.041$ por cápsula \\
\hline
\end{tabular}

Fuente: Resolución 0001-DNPI-IEPI emitido por el Instituto Ecuatoriano de Propiedad Intelectual. 
Hay lecciones importantes en este caso para las naciones que tratan de aplicar las disposiciones obligatorias de licencia disponibles en el marco del Acuerdo sobre los ADPIC. Las altas tasas de regalías como la dispuesta en el Reino Unido, podrían socavar el objetivo de hacer accesible los medicamentos para los consumidores con bajos ingresos; bajas tasas de regalías, como en la experiencia canadiense, podrían ser la base, en el supuesto de que otras condiciones son satisfechas, para el suministro de fármacos competitivos al tiempo que compensa a los titulares de patentes al menos en cierta medida por sus contribuciones a la investigación y desarrollo. Las decisiones tomadas en los países industrializados proporcionan un amplio precedente para los derechos de fijación en el lado modesta de la gama de posibilidades.

Si bien la imposición de una licencia obligatoria conlleva una imposición unilateral de un precio determinado, el INDECOPI deberá seguir los lineamientos anteriormente mencionados para evitar caer en la trampa de convertirse en un regulador de precios y lograr el objetivo de un equilibrio entre el derecho de patentes y el derecho al acceso a la salud. 


\section{CONCLUSIONES}

1. La patente es un derecho que otorga el Estado a una persona por un tiempo establecido (normalmente 20 años) para que pueda explotar de manera exclusiva su invención dentro de un territorio determinado, la misma que debe estar dotada de novedad, altura inventiva, aplicabilidad industrial. Sin embargo, como todo derecho, no es absoluto, ya que puede enfrentar limitaciones necesarias para resguardar intereses superiores que podrían verse afectados.

2. Los derechos de propiedad intelectual, en específico las patentes, como toda regulación presentan algunas desventajas para la sociedad. la patente es un mecanismo de exclusión a terceros en lo que a la explotación económica del invento se refiere, y para ello, se erige como un monopolio legal, conferido al creador durante un tiempo específico.

3. Al otorgarse una patente se otorga un monopolio, lo que permite la obtención de un puesto privilegiado para dominar los mercados, fomentar la concentración y el alza de los precios de los productos o servicios, el entorpecimiento del abastecimiento de los países de mediana tecnología y la protección de intereses privados.

4. Por otro lado, con las patentes, las empresas tienen incentivos para el desarrollo de sus ideas sin temor a ser desplazados por otro agente que se apoye en ingeniería inversa para copiar sin incurrir en costos hundidos. A pesar de que el sistema otorga un escudo a las empresas comprometidas con la innovación, éstas incurren en un enorme riesgo, el cual debe ser recompensado. Así pues, las empresas que invierten en costos de investigación obtienen sus ganancias por la asimetría de la distribución de la recompensa; del mismo modo que en la lotería, se invierte unos cuantos soles por las probabilidades, por pequeñas que sean, de obtener una recompensa.

5. Pese a las críticas al sistema de patentes, hasta el día de hoy no se ha desarrollado un sistema alterno que genere un equilibrio entre los intereses de los privados, la 
sociedad y el Estado. Asimismo, el sistema de propiedad intelectual es un sistema perfectible que a lo largo de la historia ha venido desarrollando mecanismos para alcanzar un equilibrio adecuado entre los intereses mencionados.

6. Respecto a las patentes farmacéuticas, se debe tener en cuenta que llegar a la materia patentada (cuyo resultado finalmente es un producto o procedimiento toma un largo proceso de investigación, una fase de ensayo, pruebas, acondicionamiento y fabricación especial, con el fin de asegurar el funcionamiento, seguridad y calidad del mismo, pues la intención es lanzar el producto al mercado. Ahora bien, las etapas mencionadas no solo toman un tiempo importante, sino también, involucran cada vez más una inversión significativa de recursos económicos. En promedio, el desarrollo de un producto farmacéutico cuesta aproximadamente entre 200 y 400 millones de dólares y tiene un tiempo de vida de ocho años en el mercado antes de que pierda la protección legal.

7. El costo de inventar un nuevo fármaco - costo que incluye las extensivas pruebas requeridas para que se apruebe la venta de éste-es de cientos de millones de dólares, mientras que, para la mayoría de fármacos, el costo de copiarlos $-\mathrm{o}$ de producir un substituto idéntico- es muy bajo. Por lo tanto, la ratio del primer al segundo costo va a ser siempre alta, lo cual hace difícil que el inventor recupere sus costos sin protección por patentes (y por las razones adicionales de que el valor de los ingresos por la venta del fármaco se devalúa por el tiempo que demora en aprobarse, y que el plazo efectivo de la patente es truncado porque el periodo de protección de la patente empieza a correr cuando la patente es solicitada en vez de, años después, cuando el fármaco puede empezar a venderse.

8. Una de las principales críticas al sistema de patentes, más aun en el campo de los productos farmacéuticos corresponde al alto costo de acceso de los medicamentos para la población. En principio, los titulares de patentes no tienen un límite para la fijación de sus precios.

9. Sin embargo, los precios de los productos patentados no son irracionales, el monopolista siempre se encuentra limitado por el mercado. Si los precios son muy altos, entonces algunas personas no podrán pagarlo y por lo tanto no lo comprarán. 
En ese sentido, el monopolista pierde demasiados clientes.

10. Las estrategias de precios que maximizan los beneficios para una empresa que tiene el monopolio se alteran por la forma y la pendiente de la curva de demanda del producto. La pendiente de la curva de demanda puede verse afectado por la elasticidad de la demanda. Un monopolista será más moderado si los consumidores están más dispuestos a cambiar a un sustituto inferior o quedarse sin el bueno como los precios suben.

11. La distribución del ingreso y la riqueza en los países como el nuestro tiende a ser extremadamente desigual. Según la información del INEI, el 20\% de la población en el Perú obtuvo el 50\% de todos los ingresos. Otro dato interesante es que el $10 \%$ de la población obtuvo casi 19 veces el ingreso promedio del $10 \%$ más pobre lo que acredita una clara desigualdad económica en nuestro país.

12. Si se considera que la presencia del VIH/SIDA es uniforme en todos los deciles por ingreso, únicamente el $50 \%$ de la población con VIH/SIDA puede costear el tratamiento antirretroviral a pesar del subsidio del Estado de acuerdo al análisis realizado en el párrafo anterior. Ahora bien, el costo por acceder al tratamiento contra el SIDA es de aproximadamente 150 dólares anuales a pesar del subsidio del gobierno. El precio de tratamiento tendría que bajar a 40 dólares anuales para que toda la población tuviera acceso al mismo de acuerdo a los análisis realizados.

13. A pesar que el $50 \%$ de la población no puede acceder al tratamiento antirretroviral la tasa de mortalidad ha decrecido increíblemente. Ello gracias al apoyo de inversión privada y ONGs que brindan el tratamiento gratuito a los pacientes con VIH/SIDA.

14. Considerando que el gobierno invierte $\mathrm{S} / 38$ millones en la compra de antirretrovirales podemos concluir que el gobierno únicamente subsidia el 6 millones y medio de los medicamentos ya que el monto restante es cubierto por los pagos de los pacientes que pueden costear el tratamiento. En ese sentido, si se aplicara la licencia obligatoria generando el ahorro previsto de 21 millones de soles se estaría generando un ingreso para el Estado de 13.5 millones de soles anuales. Ello nos conlleva a preguntarnos cuál es el objetivo real de la licencia obligatoria. 
15. En los mercados que tienen un ratio eficiencia-ingresos poco favorable como el mostrado el nuestro, el costo marginal de la protección de patentes es muy alto frente a los beneficios brindados, por lo que el período óptimo de protección - o el tipo de protección debe ser menor. Asimismo, dicho ratio deberá ser tomado en consideración para la adopción de una licencia obligatoria.

16. Uno de los conflictos más básicos e importantes que subyacen a la regulación y política pública del estado es el equilibrio perfecto de los intereses de la sociedad. Ello no es ajeno en la regulación de la propiedad intelectual donde distintos países trataron de encontrar un acuerdo con beneficios para todos. El resultado final de la Ronda Uruguay fue el anexo IC del Acuerdo que establece la Organización Mundial del Comercio de 1994, que incorporó un nuevo, amplio y relativamente elevado conjunto de normas mínimas internacionales de protección de la patente, que es lo que conocemos como ADPIC.

17. El Anexo IC ha sido objeto de numerosas reformas incluyendo dispositivos como (i) excepción bolar, (ii) importaciones paralelas, (iii) periodos de transición, (iv) licencias obligatorias entre otras herramientas que permiten contrarrestar situaciones de desequilibrio, las cuales si son utilizadas adecuadamente pueden generar un efecto contrario perjudicando la innovación.

18. De todas las salvaguardas anteriormente mencionadas, la licencia obligatoria es quizás el mecanismo más dominante establecido en los ADPIC. La licencia obligatoria se puede definir como una "autorización que da un Estado para producir un producto patentado o para utilizar un procedimiento patentado sin el consentimiento del titular de la patente. El titular de la patente está forzado a tolerar que un tercero realice actos de explotación sin su consentimiento."

19. La figura de la licencia obligatoria está diseñada como un supuesto excepcional, aplicable a situaciones extremas y de gravedad manifiesta, en las que exista un interés superior o bien común que hagan necesario e imprescindible que el Estado intervenga para desconocer los derechos derivados de una patente en aras de 
satisfacer esos fines superiores.

20. Si tanto le cuesta al titular de la patente desarrollar, consolidar y proteger su invento, no es sensato siquiera imaginar que sus derechos exclusivos sean "arrebatados" fácilmente. De esto se desprende que si no podrá hacerlos efectivos, deberán no solo implantarse condiciones debidamente sustentadas, sino que se tendrán que enumerar y necesariamente fundamentar las razones en base a las cuales los derechos van a afrontar ciertas limitaciones.

21. No queda duda de que el Estado tiene la obligación de cautelar el derecho a la salud e integridad de las personas, en especial de las poblaciones más vulnerables como los pacientes con VIH/SIDA, sin embargo, ello tiene que realizarse con las medidas adecuadas destinadas a lograr el fin señalado.

22. Los ciudadanos peruanos con VIH/SIDA sí cuentan con acceso a un tratamiento. Ello debido al programa gratuito del Estado "TARGA”. Como lo señala el Ministerio de Salud, el financiamiento de las intervenciones de prevención, diagnóstico, tratamiento y seguimiento de las personas con infección por VIH/SIDA se encuentran cubiertas según lo estipulado en el Plan Esencial de Aseguramiento en Salud. Así, el tratamiento antirretroviral de gran actividad (TARGA) está garantizado y es totalmente gratuito para pacientes con VIH/SIDA.

23. Entonces cabe preguntarnos la razón por la cual algunos grupos de interés se encuentran solicitando la emisión de una licencia obligatoria a pesar que los pacientes con VIH/SIDA tienen garantizado el acceso gratuito al tratamiento contra el VIH/SIDA. Sea cual sea la razón, lo cierto es que a la fecha la emisión de una licencia obligatoria no va a reducir la tasa de mortalidad del VIH/SIDA ni la incidencia de infecciones de dicha enfermedad. 


\section{Referencias}

Acemoglu, D., Johnson, S., \& Robinson, J. A. (2005). A Institutions as a fundamental cause of Long Run Growth. En P. Aghion, \& S. Durlauf, Handbook of economic Growth Vol 1 Part A.

Alexy, R. (2009). Derechos fundamentales, ponderación y racionalidad. Revista Iberoamericana de Derecho Procesal Constitucional núm. 1. enero-junio .

Arana, M. d. (2014). Marco jurídico de la Propiedad Industrial en el Perú. Anuario Andino de Derechos Intelectuales $N^{\circ} 10$.

Astudillo, F. (2012). ¿Cuáles son los motivos para el otorgamiento de una licencia obligatoria? Seminario Regional de la OMPI para algunos países de América Latina y del Caribe sobre la implementación y el uso de ciertas flexibilidades en materia de patentes. Bogotá.

Bailey, T. (2001). Innovation and access: the role of compulsory licensing in the development and distribution of HIV/AIDS drugs. Journal of Law, Technology and Policy.

Barros, P., \& Martinez-Giralt, X. (2008). On international cost-sharing of pharmaceutical R\&D. International Journal Health Care Finance Economics.

Barrow, G. (s.f.). Case study: South Africa. $B B C$.

Bate, R. (9 de febrero de 2007). Thai-ing Pharma Down. Wall Street Journal.

Baylos Corroza, H. (1993). Tratado de Derecho Industrial. Madrid.

BBC. (s.f.). Sudáfrica, una enfermedad fuera de control.

Becker, G., \& Posner, R. (30 de setiembre de 2012). ¿La ley de patentes y los derechos de autor restringen la competencia y creatividad en exceso? Obtenido de The Becker Posner Blog: http://www.becker-posner-blog.com/2012/09/do-patentand-copyright-law-restrict-competition-and-creativity-excessively-posner.html

Bermudez, J. (2006). La propiedad Intelectual en el contexto del acuerdo de la OMC sobre los ADPIC: desafíos para la salud pública. Rio: Ministerio de Salud.

Bernal Pulido, C. (2003). El principio de proporcionalidad y los derechos fundamentales. Madrid.

Bird, R. (2009). Developing Nations and the Compulsory License: Maximizing Access to Essential Medicines while Minimizing Investment Side Effects. Journal of Law, Medicine and Ethics, 209-222. 
Blackstone, W. (1979). Commentaries on the Laws of England. Chicago: University of Chicago Press.

Boldrin, M., \& Levine, D. (s.f.). Against Intellectual Monopoly. 2010: Cambridge University Press.

Boulet, P. (2001). Patentes y medicamentos en el Perú. Médicos sin fronteras. Lima.

Boytha, G. (1992). The justification of the protection of authors rights as reflected in their historical development. International Journal of Copyright $N^{\circ} 151,50$.

Brasil divulga programa de combate ã aids nos EUA. (17 de junio de 2001). Estadão.

Bullard, A. (2006). Revindicando a los piratas. ¿Es la Propiedad Intelectual un robo? . En A. Bullard, Derecho y Economía: el análisis económico de las instituciones legales. Lima: Palestra.

Burga, A. (2011). El test de ponderación o proporcionalidad de los derechos fundamentales en la jurisprudencia del Tribunal Constitucional peruano. Revista Gaceta Constitucional N ${ }^{\circ} 42$.

Carroll, J., \& Winslow, R. (25 de octubre de 2001). Bayer Agrees to Slash Prices for Cipro Drug. . Publicado el 25 de octubre de 2001. Wall Street Journal.

Cohen, J. (2007). AIDS Drugs: Brasil, Thailand overrides big pharma patents. Science .

Cohen, W. (1997). Appropriability Conditions and Why Firms Patent and Why They Do Not in the American Manufacturing Sector. Pittsburgh: Carnegie-Mellon University.

Congreso de los Estados Unidos - Oficina de Asesoría Tecnologica. (1986). Washington.

Cooper, H. (26 de junio de 2001). U.S. Drops WTO Complaint against Brazilian Patent Law. Wall Street Journal.

Corn, C. ( 1991). Pharmaceutical Patents in Brazil: Is Compulsory Licensing the solution. Boston University International Law Journal.

Correa, C. (2002). Repercusiones de la Declaración de Doha relativa al acuerdo sobre los ADPIC y la salud pública. Economía de la Salud y Medicamentos. . Buenos Aires: Universidad de Buenos Aires.

Cruz, A. (2011). La igualdad de género es clave para las respuestas al VIH y el SIDA en los lugares de trabajo. Revista Trabajo núm. 73.

Cuervo, Á. (2003). Creación empresarial y dominio de mercado: el caso del departamento de justicia de los estados unidos contra Microsoft. Infraestructuras: Transportes e industrias de red $N^{\circ} 808$.

Danzon, P., \& Towse, A. (2003). A Differential Pricing for Pharmaceuticals: Reconciling 
Access, R\&D and Patents. International Journal of Health Care Finance and Economics $N^{\circ} 3$.

Danzon, P., \& Towse, A. (2005). Theory and Implementation of Differential Pricing for Pharmaceuticals. En K. Maskus, \& J. Reichman, International Public Goods and Transfer of Technology Under a Globalized Intellectual Property Regime. Cambridge University Press.

De Roo, P. (2011). Public Non-Commercial Use' Compulsory Licensing for Pharmaceutical Drugs in Government Health Care Programs. 32 Mich. J. Int'l L. 347.

Diaz, A. (s.f.). América Latina y el Caribe: La propiedad intelectual después de los tratados de libre comercio. Santiago de Chile: 44.

Dirección de Epidemiologia del MINSA. (2013). Análisis de la situación epidemiológica del VIH/SIDA en el Perú.

Duffy, J. (2003). A minimum optimal patent term. University of Virginia School of Law.

Epstein, R. (2008). ¿The disintigration of intelectual property? A classical liberal response to a premature obituary. Stanford Law Review.

(s.f.). Estados Unidos Patente $n^{\circ}$ No. 5, 747,282.

Fernandez Shaw, F. (1975). Derecho de autor y derechos conexos en la radiodifusión española. Anuario de Derecho Civil Tomo XXVIII, 348.

Flynn, S., Hollis, A., \& Palmedo, M. (2009). An Economic Justification for Open Access to Essential Medicine Patents in Developing Countries. Journal of Law, Medicine \& Ethics $37, N^{\circ} 2$.

Forns, J. (1951). Derecho de propiedad intelectual en sus relaciones con el interés público y la cultura. Anuario de Derecho Civil Tomo IV, 998.

Franceschelli, R. (1960). Trattato di Diritto Industriale. Milan.

Franjola, D. (2009). Acuerdo sobre los ADPIC y el derecho humano a la salud: Soluciones para un mayor acceso y disponibilidad de medicamentos (Tesis). Santiago de Chile: Universidad de Chile.

Gerencia de Estudios Económicos del INDECOPI. (2002). Compras Estatales y Competencia en el Mercado de Productos Farmacéuticos. Documento de discusión 05-2002/GEE. Lima.

Gonzales, D. (s.f.). Investigación básica y aplicada en el campo de las ciencias económico administrativas. México DF: Instituto de Investigaciones y Estudios Superiores de las Ciencias Administrativas. Universidad Veracruzana. 
Guerin, O. (s.f.). El comienzo de la esperanza. $B B C U K$.

Hemphill, T. (2013). The paradox of patent assertion entities. The American.

ICTSD-UNCTAD. (s.f.). Intellectual Property Rights: Implications for Development, Policy Discussion Paper.

INEI. (2016). Evaluación de la Pobreza Monetaria 2009-2015. Lima.

Kaplinsky, R. (1988). Los derechos de Propiedad Industrial e Intelectual en la Ronda Uruguay y más allá de ella: implicancias en la política de los países en desarrollo. Junta del Acuerdo de Cartagena. Lima.

Klein, L. (2011). Las Licencias obligatorias para las patentes de medicamentos. La experiencia brasileña. Revista de Derecho Internacional Vol. 1 No. 2., 29.

Kresalja, B. (1994). El GATT y la propiedad intelectual. Análisis Internacional. N ${ }^{\circ}$ 6-7.

Kripakuri, D. (2002). Reasoned compulsory licensing: applying U.S. antitrust's rule of reason to TRIP's compulsory licensing provision. New England Law Review.

López-Tarruela, A. (2014). Las "mobile wars" llegan a Europa: "Apple vs. Samsung" desde el prisma del Derecho internacional privado. Obtenido de Blawyer: http://www.blawyer.org/2011/08/29/las-\%E2\%80\%9Cmobilewars $\%$ E2\%80\%9D-llegan-a-europa-\%E2\%80\%9Capple-vssamsung\%E2\%80\%9D-desde-el-prisma-del-derecho-internacional-privado/

Lybecker, K., \& Fowler, E. (2009). LYBECKER y FOWLER. Compulsory Licensing in Canada and Thailand: Comparing Regimes to Ensure Legitimate Use of the WTO Rules. Journal of Law, Medicine \& Ethics 37.

Madrid, I. (1998). Pharmaceuticals and Health Sector Reform in the Americas. Washington DC: Organización Panamericana de la Salud.

Mandelson, P. (2007). Carta de Mandelson a ACT UP PARIS y AIDES. Recuperado de http://www.essentialdrugs.org/edrug/archive/200709/msg00014.php.

Manufacturers Aircraft Association Inc. vs. the United States., 77 Ct. Cl. 481 (1933).

Marquez, S. (2004). Principios Generales de Derechos de Autor (Tesis). Bogotá: Pontifica Universidad Javeriana.

Miro Llinares, F. (Marzo de 2007). El futuro de la Propiedad Intelectual desde su pasado. La historia de los derechos de autor y su porvenir ante la revolución de Internet. Revista de la Facultad de Ciencias Sociales y Jurídicas del Elche. Volumen I número $2,117$.

Mohan, D. (. (Dirección). (2013). Fire in the Blood (Documental) [Película].

Moncayo, A. (2010). Seminario Regional de la OMPI-SIC. Bogotá. 
Nocera, J. (18 de abril de 2014). Greed and the Wright brothers. The New York Times.

North, D. C. (1984). Estructura y cambio en la historia económica. Madrid: Alianza Editorial.

OCDE-Foro Consultivo. (2012). Innovación y crecimiento: En busca de una frontera en movimiento tecnológico y científico.

OEA. (2012). Medidas Cautelares. Obtenido de Proceso de reforma 2012.

OMPI. (2014). Excepciones y limitaciones a los derechos conferidos por las patentes: licencias obligatorias y/o explotación por el gobierno (parte I) SCP/21/4.

OMPI. (2014). Resumen del estudio sobre alternativas al sistema de patentes que son utilizadas para apoyar las actividades de $I+D$, incluidos los mecanismos de tira y afloje, prestando especial atención a los premios de incentivo a la innovación. Ginebra.

OMPI. (setiembre de 2016). Reseña Historica de la OMPI. Obtenido de http://www.wipo.int/about-wipo/es/history.html

Oñate, T. (2010). Los países en desarrollo, la Ronda de Doha y el acuerdo de los ADPIC. Opinión Jurídica Vol. 9 No. 18, 132.

Organización Mundial de la Salud. (2005). Remuneration Guidelines for non-voluntary use of a patent on medical technologies. Health Economics and Drugs. TCM Series $N^{\circ} 18$.

Organización Mundial del Comercio. (25 de junio de 2007). Canada is first to notify compulsory license to export generic drug. Trips and public health. Obtenido de http://www.wto.org/english/news_e/news07_e/ trips_health_notif_oct07_e.htm

Ortun, V. (2005). Patentes, regulación de precios e innovación en la industria farmacéutica. CUADERNOS ECONÓMICOS DE I.C.E. N 67., 193.

Otamendi, J. (2006). Las Patentes y la Salud Pública. Congreso Internacional Propiedad Intelectual. Venezuela: UNIMAR.

Outterson, K. (2004). Pharmaceutical Arbitrage: Balancing Access and Innovation in International Prescription Drug Markets. Yale Journal Health Policy, Law \& Ethics Vol. 5.

Outterson, K., \& Aaron, K. (2008). Market-Based Licenses for HPV Vaccines in Developing Countries. Health Affairs 27.

Packard, J. (2007). Recent examples of the use of compulsory licensing. Knowledge Ecology International.

Pasco-Font, R. (2008). Fundamentos de economía pública. Lima: Centro de 
Investigación de la Universidad del Pacifico.

Pasquel, E. (2004). Una visión crítica de la propiedad intelectual. ¿Por qué eliminar las patentes, los derechos de autor y el subsidio estatal a la producción de información? Revista de economía y derecho. Vol. $1 N^{\circ} 3$.

Ramsey, F. (1927). A Contribution to the Theory of Taxation. Economic Journal $N^{\circ} 37$.

Redacción. (2 de setiembre de 2014). Estado gasta 200 millones al año tratamiento VIH. El Comercio.

Reichman, J. (2009). Compulsory licensing of patented pharmaceuticals inventions: Evaluating the options. 37 Journal of Law, Medicine and Ethics.

Republica, L. (18 de noviembre de 2015). Cuanto cuesta el tratamiento del VIH en Peru. La Republica.

Resolución 182-1997/TDC (Tribunal de Defensa de la Competencia 1997).

Rodriguez Spinelli, F. (2008). El sistema de patentes y el desarrollo tecnológico: Algunas consideraciones en el marco de la libre competencia. Revista Propiedad Intelectual. Nro. 11. Año VII, 87.

Rubio, A. (1996). La Propiedad Intelectual y el Libre Comercio Hemisférico.

Sackur, S. (s.f.). Farmacéuticas. $B B C U K$.

Satarawala Chopra, N., \& Muthappa, D. (2012). The Curious Case of Compulsory Licensing in India. Competition Law International, Vol. 8 No 2.

Schacht, W., \& Thomas, J. (2002). Pharmaceutical Patent Term Extensions: A Brief Explanation. CRS Report for congress.

Scherer, F. (2004). A Note on Global Welfare in Pharmaceutical Patenting. . World Economy Vol. 27 Nro. 7.

Sichelman, T., Samuelson, P., \& Merges, R. (2010). Patenting the entrepreneurs: The Berkeley patent survey.

Sood, M. (2013). NATCO PHARMA LTD. v. BAYER Corp. and the compulsory licensing regime in India. NUJS LAW REVIEW.

Spulber, D. (2014). Prices versus Prizes: Patents, Public Policy, and the Market for Inventions.

STC 2945-2003-AA/TC, N 0033-2010-PI/TC (Tribunal Constitucional 10 de abril de 2012).

Stiglitz, J. (2008). Economic Foundations of Intellectual Property Rights. Duke Law Journal. 
T'hoen, E. (2002). TRIPS, Pharmaceutical Patents, and Access to Essential Medicines: Seattle, Doha and Beyond. Chicago Journal of International Law.

T'Hoen, E. (2002). TRIPS, Pharmaceutical Patents, and Access to Essential Medicines: Seattle, Doha and Beyond. Chicago Journal of International Law.

Tassano, H. (2015). La convergencia entre el derecho de la competencia y los derechos de propiedad intelectual. Revista de la facultad de Derecho PUCP. $N^{\circ} 74$.

Tavares, J. 1. (1986). Los mercados disputables y la competencia Schumpeteriana en las economías de industrialización reciente. El Trimestre económico. Vol. 53, No 211.

Tesher, E. (2000). Africa Waits as Drug Firms Work it out. Toronto Star.

The Associated Press. (2007). Abbott Laboratories, Thailand Abbott Laboratories Won't Introduce New Drugs in Thailand due to Breaking of Patent. Crain Chicago Business.

Theft in Thailand. (2007). Wall Street Journal (Asia ed.).

T'Hoen, E. (2002). TRIPS, Pharmaceutical Patents, and Access to Essential Medicines: Seattle, Doha and Beyond. Chicago Journal of International Law.

T'Hoen, E. (2009). The global politics of pharmaceutical monopoly power. Países Bajos.

Torres, F. (16 de diciembre de 2013). Irregular manejo de fármacos por S/.60 millones deja sin terapia a hemofílicos. El Comercio.

Tunsarawuth, S. (2007). Indonesia Mulls Compulsory Licenses on Three More HIV/AIDS Drugs. Obtenido de Intellectual Property Watch: http://www.ipwatch.org/2007/11/26/indonesia-mulls-compulsory-licences-on-three-morehivaids-drugs/

Turner, J. (1972). Las bases políticas del desarrollo económico. Una exploración en analisis político comparativo. Madrid: Euramérica.

USA Government Accountability Office. (1987). Strenghtening Worldwide Protection of Intellectual Property Rights. Washington.

Van Zimmeren, E., \& Requena, G. (2007). Ex-officio licensing in the medical sector : the French model. En E. Van Zimmeren, \& G. Requena, Gene patents and public health. Bruselas.

Young, S. (16 de mayo de 2014). Una pastilla Diaria puede prevenir el VIH para la población en riesgo. CNN Mexico.

Zachary, D. (2004). The Hybrid Foundations of Investment Treaty Arbitration. En British Yearbook of International Law Vol. 74. 


\section{ANEXO 1 \\ PROYECTO DE PROCEDIMIENTO DE DECLARATORIA DE EXISTENCIA DE INTERES PÚBLICO}

Artículo $1^{\circ}$. La presente norma tiene por objeto establecer la competencia y el procedimiento para el trámite de declaratoria de la existencia de razones de interés público que refiere el artículo 65 de la Decisión 486 de la Comisión de la Comunidad Andina.

Artículo $2^{\circ}$. Para efectos del presente decreto se establecen las siguientes definiciones:

Autoridad competente: Es el Ministerio o autoridad correspondiente encargado de la formulación y adopción de las políticas y proyectos del sector que dirigen, y, que según la materia de que se trate, debe declarar mediante resolución motivada la existencia de razones de interés público para el otorgamiento de licencias obligatorias.

Declaratoria de existencia de razones de interés público: Acto administrativo mediante el cual la autoridad competente declara la existencia de razones de interés público que soportan la necesidad de someter a licencia obligatoria las patentes de invención.

Artículo $3^{\circ}$. Las personas naturales o jurídicas interesadas en que se declare la existencia de razones de interés público con el propósito de que se otorgue una licencia obligatoria sobre productos objeto de patente o por el uso integral del procedimiento patentado, podrán solicitar dicha declaratoria ante la autoridad competente correspondiente, la cual procederá conforme al procedimiento previsto en el presente lineamiento.

Artículo $4^{\circ}$. Para efectos de la declaratoria de la existencia de razones de interés público, se tendrá en cuenta lo siguiente:

1. La solicitud de declaratoria de las razones de interés público para someter a una patente a licencia obligatoria se debe presentar por el interesado ante la respectiva autoridad competente, la cual contendrá como mínimo las razones que fundamentan la petición, así como la relación de la(s) patente(s) que en criterio de los solicitantes deben ser sometidas a licencia obligatoria.

2. La autoridad competente, mediante acto motivado, dispondrá adelantar o no la respectiva actuación administrativa y comunicará dicha providencia al interesado.

3. Cuando la autoridad competente considere que terceros determinados pueden estar directamente interesados o resultar afectados con la decisión procederá a notificarlos, incluido el titular de la patente.

4. La autoridad competente para definir la solicitud de declaratoria de razones de interés público contará con un término de tres (3) meses para adoptar la decisión que corresponda, la cual será comunicada al solicitante y a los terceros interesados, en caso de haberlos.

5. La autoridad competente que expida la resolución de declaratoria de razones de interés público, la publicará en el Diario Oficial.

Artículo $5^{\circ}$. La resolución expedida por el correspondiente Ministerio o autoridad en la que se declare que existen razones de interés público que ameriten la expedición de licencia(s) obligatoria(s) deberá identificar la situación que afecta el interés general; establecer las circunstancias que llevaron a la declaratoria y los motivos por las cuales se debe licenciar la patente; además, indicará las medidas o mecanismos necesarios que se deban adoptar para conjurar dicha afectación. Los aspectos relacionados con el alcance específico de la(s) licencia(s) obligatoria(s) que se concederán serán concretados por el INDECOPI con base en lo previsto en la referida resolución, dentro del trámite a que se refiere el artículo $7^{\circ}$ del presente decreto. 
Sin perjuicio de lo aquí dispuesto, el Ministerio o autoridad que declare la existencia de razones de interés público, en el marco de sus competencias, podrá establecer medidas diferentes a la concesión de licencia(s) obligatoria(s).

Artículo $6^{\circ}$. Para efectos de la declaratoria de razones de interés público de que trata el artículo $4^{\circ}$ del presente decreto, el respectivo Ministerio o autoridad correspondiente dispondrá de un Comité Técnico creado mediante resolución expedida por estas entidades, que deberá:

a) Examinar y evaluar los documentos que se presenten;

b) Solicitar la información que deba ser presentada por el interesado, así como la adicional o complementaria a la misma;

c) Solicitar conceptos o apoyo técnico de otras entidades;

d) Recomendar al Ministro o Presidente de la Autoridad correspondiente la decisión de declarar o no la existencia de razones de interés público y, la consecuente expedición del acto administrativo a que se refiere el artículo $4^{\circ}$ del presente decreto.

El Comité podrá convocar a sus reuniones a funcionarios de cualquier entidad cuyo acompañamiento resulte pertinente o necesario (de conformidad con el mercado a que se refiere la solicitud), a efectos de analizar los asuntos que se le sometan a su consideración. Igualmente podrá invitar al peticionario para que amplíe los detalles de su solicitud, así como a los terceros interesados que se hagan parte en la actuación.

El término previsto en el artículo $4^{\circ}$ del presente decreto se suspenderá mientras el peticionario allegue la información adicional solicitada por el Comité o se aportan los conceptos solicitados a otras entidades.

El Comité elaborará un informe de recomendación y lo pondrá a disposición del peticionario, del titular de la patente, de las autoridades públicas pertinentes y de cualquier tercero interesado para que en el término de diez (10) días hábiles presenten observaciones. Vencido este término dentro de los tres (3) días hábiles siguientes, el Comité remitirá al Ministro o Presidente de la Autoridad Competente el informe de recomendación y las observaciones presentadas si las hubiere.

Artículo $7^{\circ}$. El INDECOPI, una vez se publique en el Diario Oficial y se comunique el acto administrativo a que se refiere el artículo $4^{\circ}$ del presente decreto, adelantará el trámite correspondiente para el otorgamiento de la(s) licencia(s) obligatoria(s) que se le soliciten, de acuerdo con el procedimiento que para el efecto se establezca.

La autoridad competente prestará el apoyo que al INDECOPI requiera durante dicho trámite, particularmente en lo relacionado con la determinación del periodo por el cual se concederá la licencia y el monto y las condiciones de la compensación económica.

Artículo $8^{\circ}$. Las solicitudes presentadas para la declaratoria de existencia de razones de interés público antes de la entrada en vigencia del presente decreto, se tramitarán por el procedimiento aquí previsto.

Artículo $9^{\circ}$. El presente decreto rige a partir de la fecha de su publicación y deroga las disposiciones que le sean contrarias. 


\section{ANEXO 2 \\ PROYECTO DE LEY 8542}

El Congreso de la República ha dado la Ley siguiente:

\section{LEY QUE DECLARA DE INTERES PÚBLICO EL TRATAMIENTO DE LAS ENFERMEDADES ONCOLÓGICAS, VIH/SIDA Y ESQUIZOFRENIA}

\section{Artículo 1‥- Del Objetivo de la Ley}

Declárese de interés público el tratamiento de las siguientes enfermedades:

- Oncológicas;

- VIH/SIDA;

- Esquizofrenia;

\section{Artículo $2^{\circ}$.- Otorgamiento de Licencia obligatoria}

Establézcase que los medicamentos y sus correspondientes procedimientos de obtención que tratan las enfermedades señaladas en el artículo $1^{\circ}$ y que a la fecha $o$ a futuro gocen de patentes en nuestro país, serán objeto de licencias obligatorias, las mismas que deberán ser otorgadas por el INDECOPI a favor de empresas farmacéuticas, nacionales o extranjeras, en el marco de lo establecido por la presente ley, en concordancia con el artículo $65^{\circ}$ de la Decisión 486 de la Comunidad Andina de Naciones.

\section{Artículo $3^{\circ}$.- Regalías}

El INDECOPI fijará el monto de la regalía que el licenciatario pagará al titular de la patente como reconocimiento a su derecho de inventor. En ningún caso la regalía podrá exceder el $6 \%$ del valor de venta neta del producto.

\section{Artículo $4^{\circ}$.- De la Seguridad y eficacia del medicamento}

El titular de la patente no podrá exigir al licenciatario condiciones adicionales a las establecidas por la Dirección General de Medicamentos Insumos y Drogas (DIGEMID) para la fabricación y/o comercialización del producto en el Perú o en los países de la Comunidad Andina de Naciones - CAN, de ser el caso.

\section{Artículo 5․-- De la Vigilancia}

La DIGEMID en coordinación con el INDECOPI, emitirá directivas relacionadas al control de calidad, precios y registro de las empresas farmacéuticas nacionales o extranjeras que se beneficien con la licencia obligatoria establecida en el artículo $2^{\circ}$.

\section{Artículo 6 ${ }^{\circ}$ - Plazo de Vigencia}

La licencias obligatorias se otorgarán hasta que el vencimiento de la patente y/o mientras permanezcan vigentes las condiciones de interés público declaradas en el artículo $1^{\circ}$ de la presente ley. 


\section{DISPOSICIÓN FINAL}

\section{UNICA.- De la Declaratoria de Interés Público de Otras Enfermedades}

La incorporación de otras enfermedades dentro de los alcances de la presente ley, atendiendo criterios de interés público o por emergencia nacional, será aprobada mediante Decreto Supremo con el voto aprobatorio del Consejo de Ministros y a propuesta del Ministerio de Salud.

Lima, Setiembre del 2003

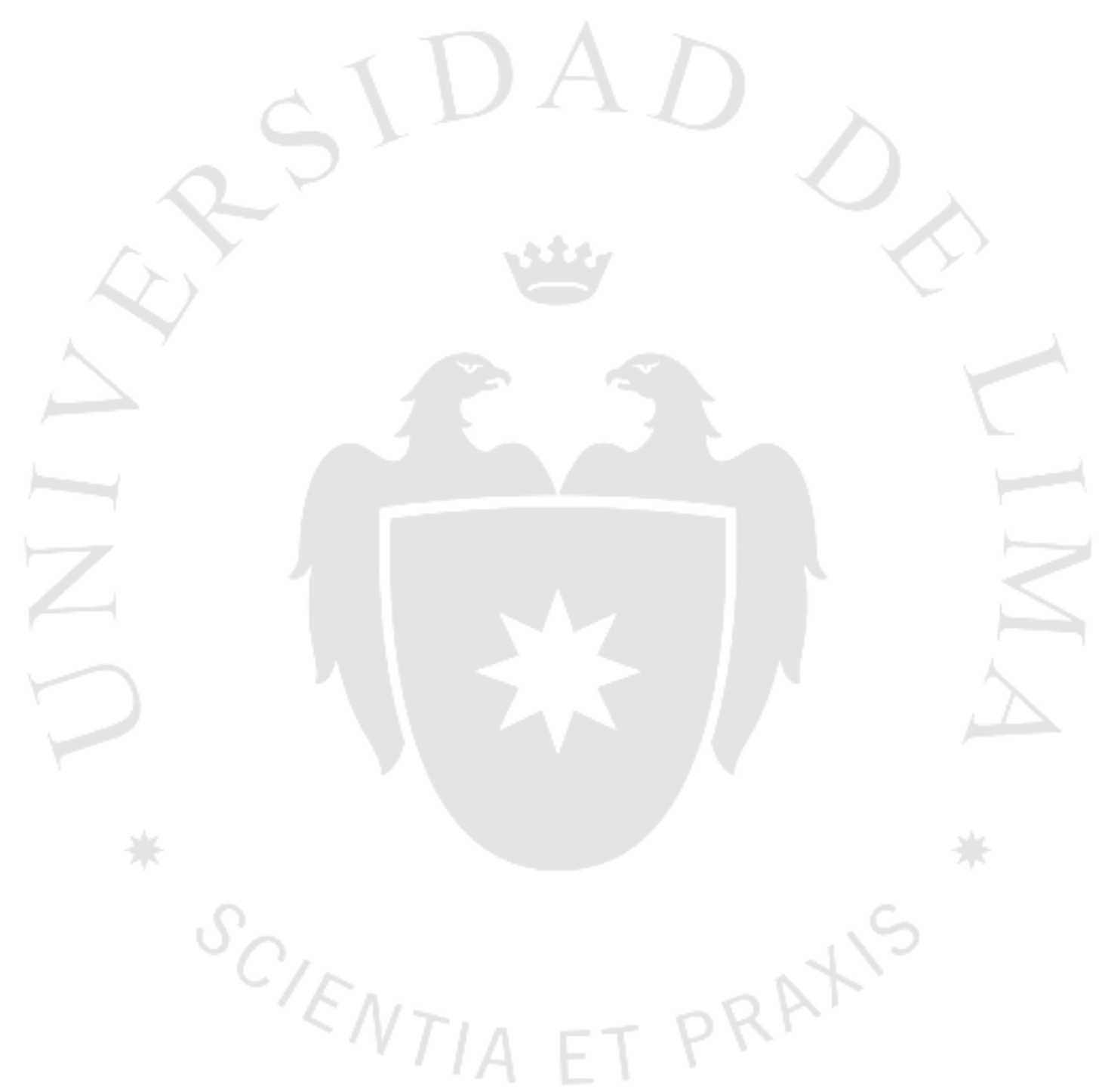




\section{ANEXO 3}

\section{Documento no publicado}

MINISTERIO DE SALUD

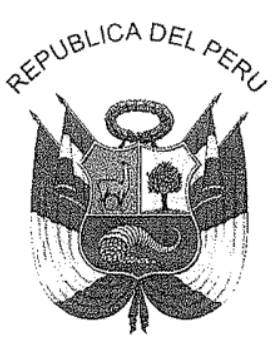

No...

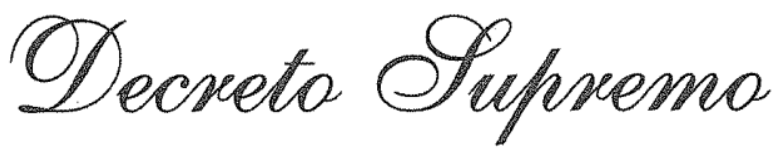

DECLARAN DE INTERÉS PÚBLICO EL ACCESO AL MEDICAMENTO

ATAZANAVIR

\section{EL PRESIDENTE DE LA REPÚBLICA}

\section{CONSIDERANDO:}

Que, la Declaración Universal de Derechos Humanos, proclamada por la Organización de las Naciones Unidas, señala en su artículo 25, entre otros aspectos, que toda persona tiene derecho a un nivel de vida adecuado que le asegure la salud y el bienestar, y en especial la asistencia médica y los servicios sociales necesarios;

Que, el artículo 7 de la Constitución Política del Perú dispone que todos tienen derecho a la protección de su salud, la del medio familiar y la de la comunidad, así como el deber de contribuir a su promoción y defensa;

Que, el artículo 9 de la Constitución Política del Perú prevé que corresponde al Estado determinar la política nacional de salud y al Poder Ejecutivo normar y supervisar su aplicación, así como diseñar y conducir esa política en forma plural y descentralizadora para facilitar a todos el acceso equitativo a los servicios de salud;

Que, asimismo, los artículos 10 y 11 de la Constitución Política del Perú establecen respectivamente, que el Estado reconoce el derecho universal y progresivo de toda persona a la seguridad social y que el Estado garantiza el libre acceso a las prestaciones de salud;

Que, los numerales I y II del Título Preliminar de la Ley $N^{\circ} 26842$, Ley General de Salud disponen que la salud es condición indispensable del desarrollo humano y medio fundamental para alcanzar el bienestar individual y colectivo, siendo responsabilidad del Estado regular, vigilar y promover la protección de la salud;

Que, los numerales 1) y 6) del artículo 3 del Decreto Legislativo $N^{\circ} 1161$, Ley de Organización y Funciones del Ministerio de Salud establecen que el Ministerio de Salud 
es competente en salud de las personas, así como en productos farmacéuticos y productos sanitarios, dispositivos médicos y establecimientos farmacéuticos;

Que, los literales a) y b) del artículo 5 de la norma legal acotada señalan que son funciones rectoras del Ministerio de Salud el formular, planear, dirigir, coordinar, ejecutar, supervisar y evaluar la política nacional y sectorial de Promoción de la Salud, Prevención de Enfermedades, Recuperación y Rehabilitación en Salud, bajo su competencia, así como el dictar normas y lineamientos técnicos para la adecuada ejecución y supervisión de dichas políticas nacionales y sectoriales y realiza el seguimiento y evaluación respecto del desempeño y obtención de resultados alcanzados en las mismas;

Que, la Ley $N^{\circ} 29459$, Ley de los Productos Farmacéuticos, Dispositivos Médicos y Productos Sanitarios define y establece los principios, normas, criterios y exigencias básicas sobre los productos farmacéuticos, dispositivos médicos y productos sanitarios de uso en seres humanos, en concordancia con la Politica Nacional de Salud y la Politica Nacional de Medicamentos, las cuales deben ser consideradas por el Estado prioridades dentro del conjunto de políticas sociales que permitan un acceso oportuno, equitativo y con calidad a los servicios de salud;

Que, asimismo, el numeral 6 del artículo 3 de la precitada Ley ha previsto que los procesos y actividades relacionados con los productos farmacéuticos, dispositivos médicos y productos sanitarios de uso en seres humanos, en cuanto sea aplicable a cada caso, se sustenta en el principio de equidad, por el cual es deber del Estado asegurar la accesibilidad equitativa a los productos farmacéuticos y dispositivos médicos esenciales como bienes públicos de salud, en relación con las necesidades de las poblaciones y de las personas, siendo objetivo de la salud pública reducir las inequidades sociales en la situación de salud, superando la exclusión social;

Que, el artículo 27 de la mencionada Ley establece que la Autoridad Nacional de Salud tiene la facultad de aplicar las limitaciones y excepciones previstas en el Acuerdo sobre los aspectos de los derechos de la Propiedad Intelectual relacionados al Comercio (ADPIC); sus enmiendas y la Declaratoria de DOHA;

Que, mediante Ley $\mathrm{N}^{\circ} 26626$, modificada por el artículo 1 de la Ley $\mathrm{N}^{\circ} 28243$, se declaró de necesidad nacional e interés público la lucha contra la infección por el Virus de Inmunodeficiencia Humana (VIH), el Síndrome de Inmunodeficiencia Adquirida (SIDA) y las Infecciones de Transmisión Sexual (ITS);

Que, el literal c del numeral 7.2 del artículo 7 de la precitada Ley, modificada por la Ley $\mathrm{N}^{\circ} 28243$, señala que la atención integral de salud comprende la intervención de salud, referida al suministro de medicamentos requeridos para el tratamiento adecuado e integral de la infección por el VIH y SIDA, que en el momento se consideren eficaces para prolongar y mejorar la calidad de vida de las personas que viven con VIH y SIDA, estableciendo la gratuidad progresiva en el tratamiento antirretroviral, con prioridad en las personas en situaciones de vulnerabilidad y pobreza extrema;

Que, el producto Atazanavir está definido como un medicamento esencial, incluido en el Documento Técnico: Petitorio Nacional Único de Medicamentos Esenciales del Sector Salud, aprobado por Resolución Ministerial N ${ }^{\circ} 399-2015 / M I N S A$ y en el esquema de tratamiento antirretroviral contenido en la Norma Técnica de Salud $\mathrm{N}^{\circ} 097-$ 


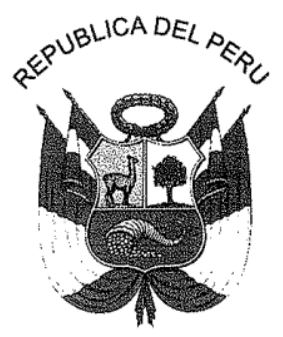

No.

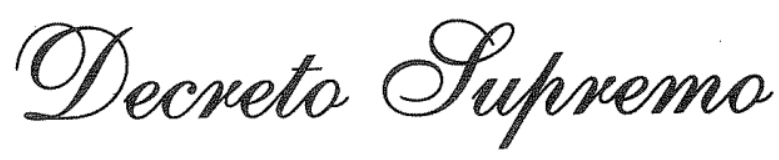

MINSAIDGSP-V.02 "Norma Técnica de Salud de Atención Integral del Adulto con Infección por el Virus de la Inmunodeficiencia Humana (VIH)", aprobada con Resolución Ministerial No 962-2014/MINSA;

Que, la Declaración relativa al Acuerdo sobre los ADPIC y la Salud Pública, adoptada en Doha, Catar, el 14 de noviembre de 2001, por los países miembros de la Organización Mundial del Comercio - OMC, señala en su numeral 1 que los países miembros de esa Organización reconocen la gravedad de los problemas de salud pública que afligen a muchos países en desarrollo y paises menos desarrollados, especialmente que afligen a muchos paises en desarrollo y paises menos desarrollados, especialmente que la protección a la propiedad intelectual es importante para la producción de nuevos medicamentos y también reconoce las preocupaciones de dichos países con respecto a los efectos de la propiedad intelectual sobre los precios;

Que, asimismo, en los numerales 4 y 5 de la precitada Declaración se convino que el Acuerdo sobre los Aspectos de los Derechos de Propiedad Intelectual Relacionados con el Comercio - ADPIC no impide ni deberá impedir que los paises miembros adopten medidas para proteger la salud pública, reiterando el compromiso con el Acuerdo sobre los ADPIC y afirmando que este instrumento internacional puede y debe ser interpretado y aplicado de modo que implique el apoyo al derecho de los países miembros de la Organización Mundial del Comercio - OMC a proteger la salud pública y, en particular, de Organización Mundial del Comercio - OMC a proteger la salud pública y, entido el derecho de los países miembros de la OMC a usar, en toda su plenitud, los dispositivos del Acuerdo sobre los ADPIC que prevén flexibilidades para tal fin, entre los que se Acuerdo sobre los ADPIC que prevén flexibilidades para tal fin, entre los que se conceder licencias obligatorias, así como la libertad para determinar las bases en que tales licencias son concedidas;

Que, el artículo 7 del referido Acuerdo sobre los ADPIC estipula, entre otras cosas, que la protección y la observancia de los derechos de propiedad intelectual deberán contribuir a la promoción de la innovación tecnológica y a la transferencia y difusión de la tecnología de modo que favorezcan el bienestar social y económico y el equilibrio de derechos y obligaciones; 
Que, el artículo 8 del mismo Acuerdo sobre los ADPIC estipula, entre otras cosas que los países miembros de la OMC podrán adoptar las medidas necesarias para proteger la salud pública y la nutrición de la población, siempre que esas medidas sean compatibles con lo dispuesto en ese Acuerdo; y, que podrá ser necesario aplicar medidas apropiadas, compatibles con lo dispuesto en ese Acuerdo derechos de propiedad intelectual por sus titulares o el recurso a prácticas que limiten de manera injustificable el comercio o redunden en detrimento de la transferencia internacional de tecnología;

Que, los artículos 30 y 31 del referido Acuerdo sobre los ADPIC han previsto la posibilidad de uso del objeto de la patente sin autorización de su titular, entre otros bajo la modalidad del uso público no comercial;

Que, el artículo 65 de la Decisión 486 de la Comunidad Andina - Régimen Común sobre Propiedad Industrial dispone que: "Previa declaratoria de un País Miembro de la existencia de razones de interés público, de emergencia, o de seguridad nacional y sólo mientras estas razones permanezcan, en cualquier momento se podrá someter la patente a licencia obligatoria. En tal caso, la oficina nacional competente otorgará las licencias que se le soliciten. El titular de la patente objeto de la licencia será notificado cuando sea razonablemente posible (...)";

Que, el artículo 40 del Decreto Legislativo No 1075, Disposiciones Complementarias a la Decisión 486 de la Comisión de la Comunidad Andina que establece el Régimen Común sobre Propiedad Industrial, modificado por el artículo 9 de la Ley $\mathrm{N}^{\circ}$ 29316, señala que: "Previa declaratoria, mediante decreto supremo, de la existencia de razones de interés público, de emergencia o de seguridad nacional; esto es, emergencia nacional $u$ otras circunstancias de extrema urgencia o en casos de uso público no comercial; y solo mientras estas razones permanezcan, en cualquier momento se podrá someter la patente a licencia obligatoria. En tal caso, se otorgarán las licencias que se soliciten. El titular de la patente objeto de la licencia será notificado cuando sea razonablemente posible. La Dirección Nacional Competente establecerá el alcance o extensión de la licencia obligatoria, especificando en particular, el periodo por el cual se concede, el objeto de la licencia, el monto y las condiciones de la compensación económica.(...);

Que, las entidades del sector público que atienden pacientes con VIH/Sida vienen adquiriendo el producto Atazanavir desde el año 2004, siendo que el monto total de las compras realizadas entre 2004 y 2015 asciende a S/. 124162438 y en el año 2013 las todo el gasto destinado a medicamentos antirretrovirales, el gasto por Atazanavir representó para el Ministerio de Salud y el Seguro Social del Perú el $52 \%$ y $53.2 \%$, respectivamente;

Que, el producto Atazanavir ofertado en el Perú es un medicamento de la empresa Bristol-Myers Squibb, cuyo precio es sustancialmente mayor en comparación con varios países de ingresos per cápita equivalentes o superiores a los del Perú, tanto en el sector privado como en el sector público;

Que, el Ministerio de Salud durante el año 2014, realizó gestiones con las empresas Bristol-Myers Squibb Perú S.A. y Bristol-Myers Squibb (Estados Unidos de Norteamérica) para reducir el precio del medicamento Reyataz®, incluso se solicitó la 


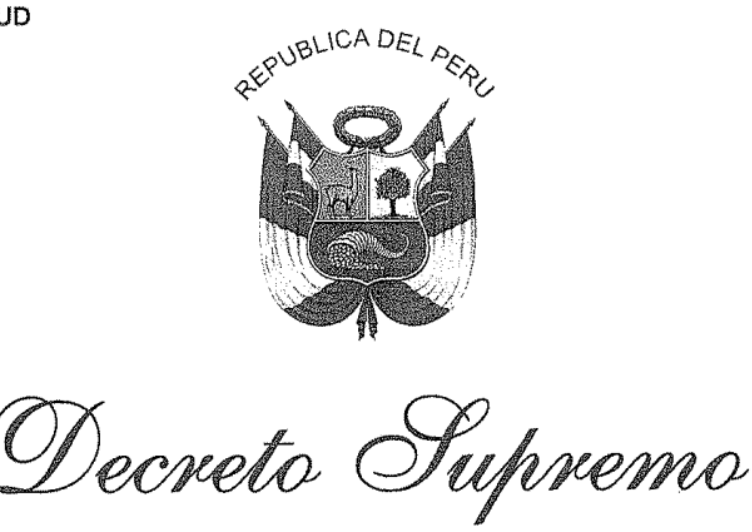

No...

incorporación del Perú en el alcance geográfico del Acuerdo de Licencia y Transferencia Tecnológica firmado entre la compañía Bristol-Myers Squibb y el Medicine Patent Pool (MPP), el cual podría haber beneficiado a nuestro país, no obteniéndose resultados satisfactorios a la fecha;

Que, a efecto de proteger y salvaguardar la salud de las personas y sobre todo quellas que se encuentran en estado de vulnerabilidad, resulta necesario declarar de interés público el acceso, para uso público no comercial, al producto Atazanavir utilizado en el tratamiento para el VIH/SIDA;

En uso de las atribuciones conferidas por el numeral 8 del artículo 118 de la Constitución Política del Perú y la Ley $N^{\circ} 29158$, Ley Orgánica del Poder Ejecutivo;

\section{DECRETA:}

Artículo 1.- Declaración de interés público

Declárese de interés público el acceso al medicamento Atazanavir utilizado en el tratamiento para el VIH/SIDA.

Artículo 2.- De las licencias

El Instituto Nacional de Defensa de la Competencia y de la Protección de la Propiedad Intelectual (INDECOPI) podrá otorgar licencias obligatorias, bajo la modalidad de uso público no comercial, respecto de toda patente de invención referida al medicamento Atazanavir, de acuerdo a sus atribuciones y en las condiciones establecidas en la normativa legal aplicable.

Artículo 3.- Refrendo

El presente Decreto Supremo será refrendado por el Presidente del Consejo de Ministros, el Ministro de Trabajo y Promoción del Empleo y la Ministra de Salud.

Dado en la Casa de Gobierno, en Lima, a los 


\section{EXPOSICION DE MOTIVOS}

\section{ANTECEDENTES}

El artículo 7 de la Constitución Política del Perú dispone que todos tienen derecho a la protección de su salud, la del medio familiar y la de la comunidad, así como el deber de contribuir a su promoción y defensa.

Asimismo, el artículo 9 de la referida Constitución Política del Perú prevé que corresponde al Estado determinar la política nacional de salud, y al Poder Ejecutivo normar y supervisar su aplicación, así como diseñar y conducir esa política en forma plural y descentralizadora para facilitar a todos el acceso equitativo a los servicios de salud.

Los artículos 10 y 11 de la Constitución Política del Perú establecen respectivamente, que el Estado reconoce el derecho universal y progresivo de toda persona a la seguridad social y que el Estado garantiza el libre acceso a las prestaciones de salud.

Los numerales I y II del Título Preliminar de la Ley N²6842, Ley General de Salud disponen que la salud es condición indispensable del desarrollo humano y medio fundamental para alcanzar el bienestar individual y colectivo, siendo responsabilidad del Estado regular, vigilar y promover la protección de la salud.

En ese mismo sentido, el numeral XII del Título Preliminar de la precitada Ley establece que: "El ejercicio del derecho a la propiedad, a la inviolabilidad del domicilio, al libre tránsito, a la libertad de trabajo, empresa, comercio e industria asi como el ejercicio del derecho de reunión están sujetos a las limitaciones que establece la ley en resguardo de la salud pública".

Los numerales 1) y 6) del artículo 3 del Decreto Legislativo $\mathrm{N}^{\circ} 1161$, Ley de Organización y Funciones del Ministerio de Salud establece que el Ministerio de Salud es competente en salud de las personas, así como en productos farmacéuticos y sanitarios, dispositivos médicos y establecimientos farmacéuticos.

Los literales a) y b) del artículo 5 de la norma legal acotada han previsto que son funciones rectoras del Ministerio de Salud, el formular, planear, dirigir, coordinar, ejecutar, supervisar y evaluar la política nacional y sectorial de Promoción de la Salud, Prevención de Enfermedades, Recuperación y Rehabilitación en Salud, bajo su competencia, así como el dictar normas y lineamientos técnicos para la adecuada ejecución y supervisión de dichas políticas nacionales y sectoriales y realiza el seguimiento y evaluación respecto del desempeño y obtención de resultados alcanzados en las mismas.

La Ley $\mathrm{N}^{\circ}$ 29459, Ley de los Productos Farmacéuticos, Dispositivos Médicos y Productos Sanitarios define y establece los principios, normas, criterios y exigencias básicas sobre los productos farmacéuticos, dispositivos médicos y productos sanitarios de uso en seres humanos, en concordancia con la Política Nacional de Salud y la Política Nacional de Medicamentos, las cuales deben ser consideradas por el Estado prioridades dentro del conjunto de políticas sociales que permitan un acceso oportuno, equitativo y con calidad a los servicios de salud.

El artículo 3 de la precitada Ley establece que los procesos y actividades relacionados con los productos farmacéuticos, dispositivos médicos y productos sanitarios de uso en seres humanos, en cuanto sea aplicable se sustenta en el Principio de accesibilidad, por el cual, "La 
salud es considerada un derecho fundamental de las personas. El acceso al cuidado de la salud incluye el acceso a productos farmacéuticos y dispositivos médicos. Constituye un requisitos para lograr este derecho: tener el producto disponible y asequible en el lugar y momento en que sea requerido". Asimismo, el numeral 6 del referido artículo ha previsto que los procesos y actividades relacionados con los productos farmacéuticos, dispositivos médicos y productos sanitarios de uso en seres humanos, en cuanto sea aplicable a cada caso, se sustenta en el principio de equidad, por el cual es deber del Estado asegurar la accesibilidad equitativa a los productos farmacéuticos y dispositivos médicos esenciales, como bienes públicos de salud, en relación con las necesidades de las poblaciones y de las personas siendo objetivo de la salud pública reducir las inequidades sociales en la situación de salud superando la exclusión social;

Asimismo, el artículo 27 establece que la Autoridad Nacional de Salud tiene la facultad de aplicar las limitaciones y excepciones previstas en el Acuerdo sobre los aspectos de los derechos de la Propiedad Intelectual relacionados al Comercio (ADPIC), sus enmiendas y la Declaratoria de DOHA.

Al respecto, el Tribunal Constitucional en su sentencia 2945-2003-AA del 20 de abril de 2003 , ha señalado lo siguiente:

\section{"(...)}

Sobre aspectos jurídicos relacionados con los derechos de propiedad intelectual relacionados con el comercio ADPIC) y la salud pública en los países en desarrollo

40. Si bien el tema no se deriva directamente del petitorio de la demanda, este Tribunal considera conveniente pronunciarse sobre los aspectos relativos a derechos de propiedad intelectual reconocidos en compromisos internacionales; asi como sobre las excepciones que establecidas y reconocidas formalmente en diversos documentos internacionales en el marco de la Organización Mundial de Comercio, de la cual el Perú es país miembro desde 1995.

En efecto, cuando se advierta que alguna dificultad en el cumplimiento de objetivos nacionales referidos a la salud pública, con a consiguiente afectación del derecho mismo y de a la vida de los ciudadanos -específicamente en los casos relacionados con enfermedades como VIH/SIDA, tuberculosis, paludismo y otras epidemias-, se ha establecido, mediante la Declaración Ministerial de DOHA del 14 de noviembre de 2011 relativa al acuerdo sobre propiedad intelectual y la salud pública (DOHA Declaration on the TRIPS Agreement and Public Heath), que si bien la protección de la propiedad intelectual es importante para el desarrollo de nuevas medicinas, no puede dejarse de lado la preocupación respecto a su efecto en los precios; de modo que los acuerdos sobre protección de propiedad intelectual no significarán una obstrucción a los países miembros para tomar las medidas necesarias para proteger la salud pública $y$, particularmente, la promoción de medicinas para todos.

41. En tal sentido, dadas las dificultades para la provisión de medicinas esenciales para el tratamiento de enfermedades como el VIH/SIDA, es recomendable que el Estado peruano, dentro de su política de salud concerniente a la prevención y protección contra el $V I H / S I D A, y$ como sujeto de derechos y deberes como país miembro de la OMC, utilice el máximo de provisiones y medidas que mediante una interpretación flexible del tratado sobre protección a la propiedad intelectual, claro está, dentro de los márgenes establecidos en el acuerdo del DOHA, le permita el cumplimiento de sus objetivos trazados en su politica de salud. 
De otro lado, mediante Ley $\mathrm{N}^{\circ} 26626$, modificada por el artículo 1 de la Ley $\mathrm{N}^{\circ} 28243$, se declaró de necesidad nacional e interés público la lucha contra la infección por el Virus de Inmunodeficiencia Humana (VIH), el Síndrome de Inmunodeficiencia Adquirida (SIDA) y las Infecciones de Transmisión Sexual (ITS); estableciendo que: "Toda persona que se encuentra viviendo con VIH y SIDA, tiene derecho a recibir atención integral de salud continua y permanente por parte del Estado, a través de todos los establecimientos de salud donde tenga administración, gestión o participación directa o indirecta y a la prestación previsional que el caso requiera".

Asimismo, el literal c del numeral 7.2 del artículo 7 de la precitada Ley señala que la atención integral de salud comprende la intervención de salud, referida al suministro de medicamentos requeridos para el tratamiento adecuado e integral de la infección por el VIH/SIDA, que en el momento se consideren eficaces para prolongar y mejorar la calidad de vida de las personas que viven con $\mathrm{VIH} / \mathrm{SIDA}$, estableciendo la gratuidad progresiva en el tratamiento antirretroviral con prioridad en las personas en situaciones de vulnerabilidad y pobreza extrema;

En este sentido, las características del VIH/SIDA que a diferencia de otras enfermedades transmisibles, que también constituyen problemas de salud pública, no sólo presenta un alto riesgo de transmisión, sino que es una enfermedad infecciosa crónica que no tiene cura conocida. Es decir, el tratamiento, una vez diagnosticada la infección, debe ser permanente a lo largo de toda la vida de la persona. Por estas características, el Estado peruano garantiza el acceso gratuito a todas las personas infectadas con VIH por ser un problema de salud de interés público, conforme a lo dispuesto en la Ley $\mathrm{N}^{\circ} 26626$.

Por su parte, la entonces Dirección General de Salud de las Personas, hoy Dirección General de Intervenciones Estratégicas en Salud Pública, en su Informe $N^{\circ} 111-2014-E S N$ PC ITS VIH-SIDA-DSS-DGSP/MINSA, explica que desde la aparición del tratamiento antirretroviral de gran actividad (TARGA) en los años 90, la infección por el $\mathrm{VIH}$ se ha convertido en una infección crónica que permite a los pacientes tener una sobre vida prolongada constituyéndose en una terapia combinada que reduce la multiplicación del virus de la inmunodeficiencia humana (VIH) y permite prolongar y mejorar la calidad de vida de las personas que viven con $\mathrm{VIH}$ y además contribuye a reducir la transmisión o contagio a otras personas sanas de la comunidad; por lo que, al asegurar la continuidad del tratamiento, se tiene un efecto adicional para prevenir nuevas infecciones en el país.

Información sobre el Atazanavir.-

Atazanavir, Lopinavir, Darunavir y Ritonavir son medicamentos que pertenecen a la clase de antirretrovirales denominada inhibidores de la proteasa (IP), incluidos en la Norma Técnica de Salud de Atención Integral del Adulto con Infección por el VIH del Ministerio de Salud (NTS $N^{\circ}$ 097-MINSANDGSP-V.02), los mismos que están recomendados en las guías de tratamiento de la Organización Mundial de la Salud. Son denominados medicamentos de segunda línea.

Estos medicamentos están indicados en pacientes que han fallado a un primer esquema de tratamiento antirretroviral. La indicación del uso de los medicamentos inhibidores de la proteasa se realiza teniendo en cuenta criterios de seguridad, tolerabilidad y pruebas de resistencia, haciéndolo de manera secuencial y estratégica, con la finalidad de prevenir el desarrollo de resistencia y preservar opciones duraderas de tratamiento para los pacientes.

La evidencia disponible señala que el Atazanavir potenciado con Ritonavir está indicado para el tratamiento de pacientes viviendo con VIH/SIDA que presentan falla a medicamentos de la primera línea. 
Los medicamentos antiretrovirales usados en el tratamiento de segunda línea son tan importantes como los de primera línea y los de esquemas especiales. No hay diferencia entre unos y otros en términos de protección de salud, todos son necesarios, así lo recomiendan las guias nacionales e internacionales. La razón para establecer esquemas de primera y segunda línea se basa en la evidencia científica [OMS, guias consolidadas para el tratamiento de la infección or $\mathrm{VIH}, 2013]$. Es importante que una persona con $\mathrm{VIH}$ reciba un tratamiento adecuado en cualquier línea de tratamiento, ya que beneficia su salud pero además de ello, minimiza la posibilidad de transmisión del virus a otras personas. (OMS, Antiretroviral Treatment as prevention of HIV and TB, 2012).

\section{Principales cambios de la nueva Norma Técnica aprobada en el 2014.-}

En la nueva norma de tratamiento antirretroviral se busca mejorar e incrementar el acceso temprano al tratamiento antirretroviral, a través de la simplificación del algoritmo de pruebas de diagnóstico. Esto significa el inicio de la terapia cuando el paciente aún no tiene deteriorado su sistema inmunológico.

Este cambio permite aumentar la cobertura de tratamiento antirretroviral para las personas viviendo con $\mathrm{VIH}$. En principio, este incremento de cobertura beneficiará a pacientes vírgenes al tratamiento (también denominados "pacientes naive"), que recibirán medicamentos con esquemas de primera línea. Sin embargo, se debe tener en cuenta que un $5 \%$ de pacientes en esquemas de primera línea deben cambiar a la segunda línea por la aparición de mutaciones espontáneas inevitables del virus, el cual se vuelve resistente al tratamiento. La aparición de estos virus resistentes ocasiona que este grupo de pacientes cambien a medicamentos de segunda línea y el número de pacientes con Atazanavir se incrementará en el tiempo de modo progresivo e inevitable.

El Ministerio de Salud dispone y trabaja enfáticamente dentro de sus estrategias ,el componente de adherencia al tratamiento antirretroviral, definida como "el grado en que el comportamiento de una persona se ajusta a la toma adecuada de antirretrovirales, sigue un régimen alimentario y ejecuta cambios en el estilo de vida, en concordancia con las recomendaciones del personal de salud", incorporando incluso a los agentes de soporte comunitario en el monitoreo de la adherencia al tratamiento (NTS 097 - MINSA/DGSP V.02).

Si bien, existen también otros inhibidores de la proteasa como el Lopinavir y Darunavir que costán indicados como parte de los esquemas TARGA, el uso inicial de Atazanavir combinado (potenciado) con Ritonavir permite reservar el uso posterior de Lopinavir con Ritonavir en los pacientes que fallan a Atazanavir, debido a que las mutaciones que aparecen contra el Atazanavir no afectan al Lopinavir con Ritonavir.

Además, Atazanavir tiene mayor seguridad que Lopinavir porque puede ocasionar menores efectos secundarios a nivel de lípidos, aparato cardiovascular y metabólico, por lo cual es de primera elección en pacientes adultos mayores y aquellos que también padecen de enfermedades como hipertensión arterial y diabetes. Su inclusión en la nueva norma técnica fue recomendado por el Comité de Expertos de Atención Integral del Adulto Infectado con el VIH/SIDA, en su Oficio $N^{\circ}$ 001-2014 CODEAVIS, y el Instituto Nacional de Salud, a través de Oficio $N^{\circ}$ 556-2014-J-OPE/INS. Además, se basa en las recomendaciones establecidas en los documentos técnicos de organismos internacionales, como la OMS. 
Características de la demanda del Atazanavir por el Programa de Tratamiento del Ministerio de Salud .-

En ese sentido y de acuerdo al reporte de monitoreo de la entonces Dirección General de Salud de las Personas de julio de 2014 "(...) 1,590 personas de las 23,881 personas que reciben TARGA en establecimientos de salud del MINSA tienen Atazanavir en sus esquemas, es decir, el $6.7 \%$ del total.

Si consideramos que esta proporción se va a mantener en el tiempo, y se le suma una proporción adicional por las nuevas estrategias para ampliar acceso al diagnóstico y para iniciar tratamiento temprano sin deterioro del sistema inmune, se obtiene una proyección de pacientes al 2021 que además considera una proporción constante y un escenario de reducción de brechas de tratamiento hacia el 2021. Los resultados, tal como se muestra en la Tabla 1, muestran que se tendrá un incremento del $8 \%$ anual en promedio de personas en tratamiento".

Tabla 1. Proyecciones de uso de Atazanavir en esquemas de tratamiento antiriretroviral, Perú 2015-2021

\begin{tabular}{|c|c|c|c|c|c|c|c|}
\hline Hesentision & 2015 & 2017 & $\frac{10617}{20}$ & 8018 & 2098 & 2020 & 2002 \\
\hline Arazans r $300 \mathrm{mg}$ & 1990 & 2,160 & 28339 & 25550 & 2700 & 2900 & 8100 \\
\hline Argan ayir $200 \mathrm{mo}$ & 440 & 480 & 520 & 566 & 600 & 640 & 690 \\
\hline Total Estingad & 2,430 & 2630 & 2880 & 3,070 & 3300 & 3540 & 3.790 \\
\hline
\end{tabular}

La entonces Dirección de Abastecimiento de Recursos Estratégicos en Salud - DARES, hoy Centro Nacional de Abastecimiento de Recursos Estratégicos en Salud en su Nota Informativa $\mathrm{N}^{\circ}$ 004-2015-DARES/MINSA, señala que el Ministerio de Salud cobertura de forma gratuita las intervenciones relacionadas con el diagnóstico y tratamiento de $\mathrm{VIH} / \mathrm{SIDA}$ y el respectivo tratamiento antirretroviral según los esquemas establecidos en la NTS $N^{\circ}$ 097-MINSAIDGSPV.02: "Norma Técnica de Atención Integral del Adulto con Infección por el Virus de R/ESPINOZAC, Inmunodeficiencia Humana (VIH)", aprobada mediante Resolución Ministerial Nº 962-2014MINSA. Los esquemas de tratamiento incluyen el uso del medicamento Atazanavir, señalando además que en los últimos años en base al número de pacientes estimados por la entonces DGSP, la entonces DARES ha requerido comprar mayores volúmenes de Atazanavir $300 \mathrm{mg}$ TAB para cubrir la necesidad de abastecimiento del ámbito nacional; sin embargo, los precios ofertados por el proveedor no se han reducido.

Asimismo, en el 2013 ha manifestado que el producto Atazanavir tiene un precio de adquisición de S/. 29.17 bajo la marca "REYATAZ®" de la empresa Bristol-Myers Squibb. Los precios de dicho medicamento en los dos últimos años han significado para la entonces DARES cerca del $52 \%$ del gasto del total para medicamentos antirretrovirales, situación que de persistir indudablemente afectará la sostenibilidad financiera a lo largo del tiempo, principalmente ante un contexto de aumento de la cobertura de la Estrategia Sanitaria de Prevención y Control de Infecciones de Transmisión Sexual y VIH/SIDA para los siguientes años.

Características de la brecha deficitaria de presupuesto para adquisición de medicamentos en ESSALUD.- 
De otro lado, el Seguro Social de Salud - EsSalud, organismo público del Ministerio de Trabajo y Promoción del Empleo, a través del Oficio N ${ }^{\circ}$ 529-PE-ESSALUD-2014 informa que anualmente atiende a más de cinco mil personas con infección por VIH/SIDA para el 2014, de las cuales un $13 \%$ se encuentra utilizando Reyataz $®$ en las presentaciones de $200 \mathrm{mg}$ y $300 \mathrm{mg}$. Sus adquisiciones del medicamento antirretroviral Atazanavir bajo la marca Reyataz $\otimes$ se inician en el año 2004 con 720 unidades de la presentación de $200 \mathrm{mg}$, en el año 2005 ingresó la presentación de $150 \mathrm{mg}$, la misma que fue reemplazada en el año 2011 por la presentación de $300 \mathrm{mg}$. Las unidades adquiridas al igual que su consumo tienen un incremento creciente, llegando a comprar entre ambas presentaciones durante el período 2004 al 2013 , un total de $1^{\prime} 870,849$ unidades por las que ha pagado $S / .44^{\prime} 101,292.00$ de nuevos soles.

No inclusión del Perú para la firma de acuerdo de licencia voluntaria.-

En este punto, es preciso señalar que en diciembre de 2013 el Medicines Patent Pool (MPP) y la empresa Bristol-Myers Squibb firmaron un acuerdo de licencia (voluntaria) para aumentar el acceso al Atazanavir en 110 países en desarrollo, por el cual fabricantes de varios países producen versiones más asequibles de Atazanavir, el acuerdo también permite combinar este medicamento con otros para facilitar y hacer más accesible el tratamiento en los países en desarrollo. Así, se proporcionará a los titulares de sublicencias un paquete de transferencia de tecnología para facilitar la producción de Atazanavir. El Perú es uno de los países que no ha sido incluido en el referido acuerdo, a pesar de los requerimientos formulados por el Ministerio de Salud para formar parte del mismo.

Bajo la patente $N^{\circ} 2380$ otorgada en el Perú a favor de Bristol-Myers Squibb Holdings Ireland, se protege la sal de bisulfato de éster dimetilico del ácido $\left[3 S-\left(3 R^{\star}, 8 R^{\star}, 9 R^{\star}, 12 R^{\star}\right)\right]-3,12$-bis (1,1-dimetiletil)-8-hidroxil -4,11-dioxo-9 (fenilmetil)-6- [[4-(2-piridinil)-fenilmetil] 2,5,6,10,13 pentaazotetradecanoico, Atazanavir Sulfato. Según lo indicado por INDECOPI, dicha patente otorga a la referida empresa los derechos de exclusividad sobre la molécula Atazanavir en

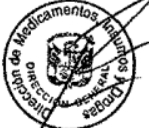
nuestro país. La vigencia de la referida patente es hasta el 20 de enero del 2019.

\section{Propuesta de Licencia obligatoria.-}

RLESPINOZAC. Con el Informe $N^{\circ}$ 04-2014-MCN/DIGEMID-DAUM-OPPF/MINSA, la DIGEMID concluye que en el país la emisión de una licencia obligatoria de uso público no comercial, prevista en los $A D P I C$, sería el camino legal para conseguir una reducción significativa de los precios del medicamento Atazanavir, considerando que:

“a) en el Perú la lucha contra la infección por el Virus de Inmunodeficiencia Humana (VIH) y el Síndrome de Inmunodeficiencia Adquirida (SIDA) ha sido declarada de necesidad nacional e interés público;

b) el Atazanavir es un medicamento incluido en la Norma Técnica de Salud de Atención Integral del Adulto con Infección por el Virus de la Inmunodeficiencia Humana (VIH);

c) el Atazanavir es un medicamento esencial que salva vidas y está incluido en el Petitorio Nacional Único de Medicamentos Esenciales el Atazanavir;

d) existe una tendencia demostrada para el incremento de la demanda y adquisición de este medicamento por los sistemas de salud públicos;

e) existe un alto impacto del Atazanavir en el financiamiento del resto de medicamentos antirretrovirales en el sector público;

f) los precios de adquisición del Atazanavir en el Perú son ampliamente superiores a los precios internacionales;

g) existe un marco juridico para que en las situaciones que lo ameriten se pueda emitir una licencia obligatoria; $y$ 
h) las licencias obligatorias son un mecanismo reconocido por la Organización Mundial del Comercio y la Organización Mundial de la Salud para mejorar el acceso de los medicamentos, especialmente en paises en vías de desarrollo".

i) La infección por el virus de inmunodeficiencia humana VIH/SIDA es hasta la fecha crónica e incurable, con tratamiento a lo largo de la vida del paciente y a pesar de que nuestro país tiene una epidemia concentrada en grupos específicos de la población más vulnerable, la incidencia es creciente.

De otro lado, el artículo 40 del Decreto Legislativo $\mathrm{N}^{\circ} 1075$ establece Disposiciones Complementarias a la Decisión 486 de la Comisión de la Comunidad Andina que establece el Régimen Común sobre Propiedad Industrial, modificado por el artículo 9 de la Ley 29316 señala lo siguiente: "Previa declaratoria, mediante decreto supremo, de la existencia de razones de interés público, de emergencia o de seguridad nacional; esto es, emergencia nacional $u$ otras circunstancias de extrema urgencia o en casos de uso público no comercial; y solo mientras estas razones permanezcan, en cualquier momento se podrá someter la patente a licencia obligatoria. En tal caso, se otorgarán las licencias que se soliciten. El titular de la patente objeto de la licencia será notificado cuando sea razonablemente posible. La Dirección Nacional Competente establecerá el alcance o extensión de la licencia obligatoria, especificando en particular, el período por el cual se concede, el objeto de la licencia, el monto y las condiciones de la compensación económica. (...)".

En el texto legal antes mencionado la "Dirección Nacional Competente" se refiere al Instituto Nacional de Defensa de la Competencia y Protección de la Propiedad Intelectual - INDECOPI, organismo autónomo encargado de administrar el sistema de otorgamiento y protección de los derechos de propiedad intelectual en todas sus manifestaciones, en sede administrativa, conforme a lo previsto en literal $\mathrm{h}$ ) del numeral 2.1 del artículo 2 del Decreto Legislativo $\mathrm{N}^{\circ}$ 1033, que aprueba la Ley de Organización y Funciones del Instituto Nacional de Defensa de la Competencia y de la Protección de la Protección de la Propiedad Intelectual.

La concesión de licencias obligatorias en este caso se basa en la necesidad pública para asegurar la sostenibilidad del acceso al producto Atazanavir, que es un medicamento de R/ESPINOZAC. necesidad crítica para controlar el HIVISIDA en los pacientes con esa enfermedad en el país La licencia obligatoria no es una "apropiación" de derechos de propiedad intelectual. El titula de una patente sometida a una licencia obligatoria puede continuar o iniciar las actividades industriales o comerciales que desee respecto de su invención. La licencia obligatoria tiene carácter "no exclusivo" de modo que no excluye al titular de la patente de su derecho de conceder otras licencias ni de explotar directamente su invento. Asimismo, el titular de la patente recibe una compensación económica

De otro lado, si bien es cierto que el Ministerio de Salud es el ente rector del Sector Salud conforme a lo dispuesto en el artículo 4 del Decreto Legislativo $\mathrm{N}^{\circ} 1161$, Ley de Organización y Funciones del Ministerio de Salud, estimamos pertinente que el Decreto Supremo debe se refrendado también por el Ministro de Trabajo y Promoción del Empleo, que forma parte del Sector Salud; y, a través del Seguro Social de Salud - EsSALUD,, institución que también adquiere el medicamento Atazanavir, como parte del tratamiento antirretroviral que se ofrece a sus asegurados. 


\section{ANÁLISIS COSTO - BENEFICIO}

Las normas constitucionales y legales aplicables en el Perú señalan que es responsabilidad del Estado regular, vigilar y promover la protección de la salud. Las prestaciones necesarias para dar cumplimiento a esas disposiciones que prevén el derecho de la población del país a la protección de su salud y reconocen que la salud es un medio fundamental para alcanzar el bienestar individual y colectivo, no pueden desvincularse del costo económico que tales prestaciones conllevan toda vez que afectan el acceso real al tratamiento.

En el Perú, la lucha contra la infección por el Virus de Inmunodeficiencia Humana (VIH) y el Síndrome de Inmunodeficiencia Adquirida (SIDA) ha sido declarada de necesidad nacional e interés público; asimismo señala que toda persona que se encuentre viviendo con VIH y SIDA tiene derecho a recibir atención integral de salud continua y permanente por parte del Estado. La atención integral de salud comprende acciones de prevención, diagnóstico, tratamiento, monitoreo, consejería pre y post diagnóstico, rehabilitación y reinserción social.

Restringir o limitar directa o indirectamente los recursos económicos requeridos para hacer realidad las prestaciones de salud pública lleva a la inviabilidad práctica de esas prestaciones y al consecuente incumplimiento de las referidas obligaciones constitucionales del Estado.

A diciembre de 2012, el Estado a través de los establecimientos de salud del MINSA Regiones, Essalud, ONG, Fuerzas Armadas y Policiales, ofrecían tratamiento antirretroviral gratuito a 26,785 adultos y 717 niños en todo el país. Desde el inicio del tratamiento antirretroviral se ha logrado reducir en más del $50 \%$ el número de defunciones por SIDA.

Las adquisiciones del Atazanavir en el sector público se iniciaron en el 2004. A lo largo de estos 11 años, los datos muestran una tendencia creciente al aumento del número de unidades de Atazanavir de $200 \mathrm{mg}$ y $300 \mathrm{mg}$, que se adquieren, siendo el Atazanavir $300 \mathrm{mg}$ el que muestra una tendencia mayor, especialmente en los últimos cuatro años.

El siguiente gráfico muestra el incremento en la adquisición del medicamento Reyataz® (nombre comercial del Atazanavir), se observa un incremento en el número de unidades que es hasta siete (07) veces mayor entre el 2011 y el 2014 


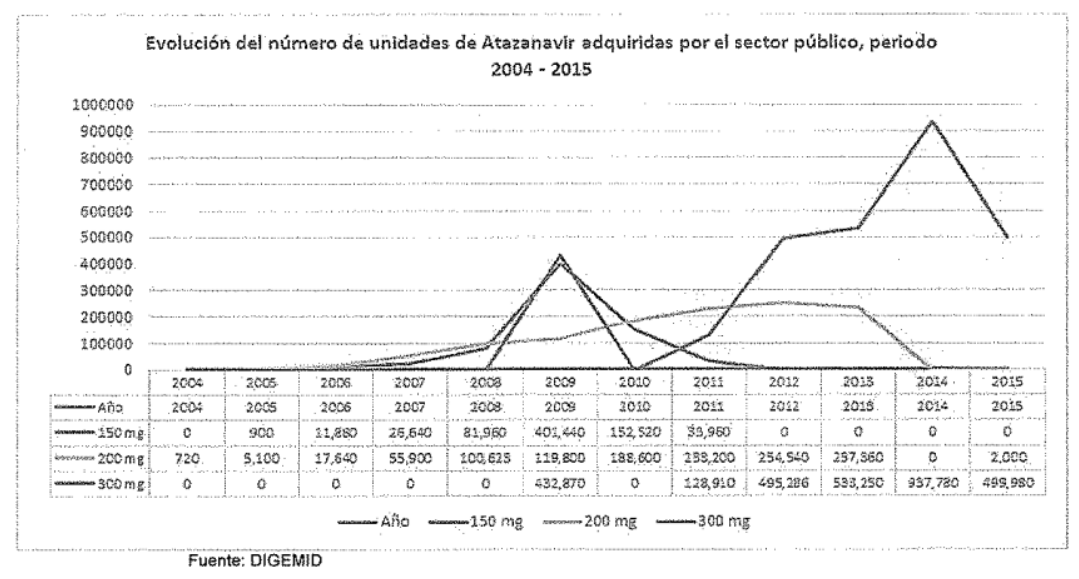

Las adquisiciones de Atazanavir realizadas por Essalud se han incrementado desde S/. $16,372.00$ en el año 2004 hasta S/. 11'363,736 en el año 2014 , haciendo un total de gasto durante ese período de más de 44 millones de nuevos soles; representando así el $30 \%$ del gasto total en medicamentos antirretrovirales en los últimos diez años. Sin embargo, para el 2013 , representó el $53.17 \%$ de su gasto total en antiretrovirales, lo que refleja el impacto que este medicamento tiene sobre el financiamiento y el acceso al tratamiento antirretroviral de gran actividad en nuestro país.

En el caso del MINSA, el gasto de ha elevado de 10.37 millones de nuevos soles en el 2012 a 21.98 millones de nuevos soles en el 2014 y representa el $56 \%$ del gasto total en medicamentos antirretrovirales, cifra que tiende a incrementarse según proyecciones realizadas. En el siguiente gráfico podemos observar también que el gasto en el medicamento antirretroviral Atazanavir no es proporcional con el número de personas en tratamiento.

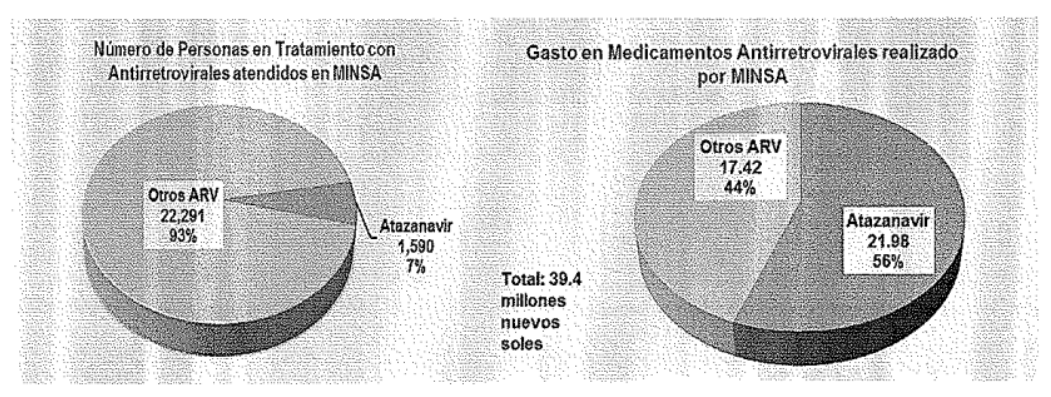

El precio unitario del Atazanavir a nivel internacional presenta variaciones dependiendo si se trata del producto innovador Reyataz ${ }^{\circledR}$ o de su versión genérica, siendo el Perú el país de la 
región en el que el precio de la versión innovadora es uno de los más alto. Por ejemplo en el Perú el precio de cada tableta de Reyataz ® de $300 \mathrm{mg}$ es USD \$ 6.0 y en Brasil USD \$1.6.

Si el Perú contara con versiones genéricas de Atazanavir se lograría reducir el impacto de gasto que el Sector Público realiza para financiar la Estrategia Sanitaria Nacional de Prevención y Control de las ITS, VIH y SIDA (ESN VIH/SIDA), garantizando así la sostenibilidad del acceso al tratamiento para las personas afectadas.

El siguiente cuadro muestra la diferencia de costo anual de tratamiento por persona para la presentación de $300 \mathrm{mg}$. Para esta comparación se ha utilizado el precio más alto del medicamento Reyataz $®$ vendido en el Perú versus el precio de referencia de laboratorios que venden el medicamento genérico.

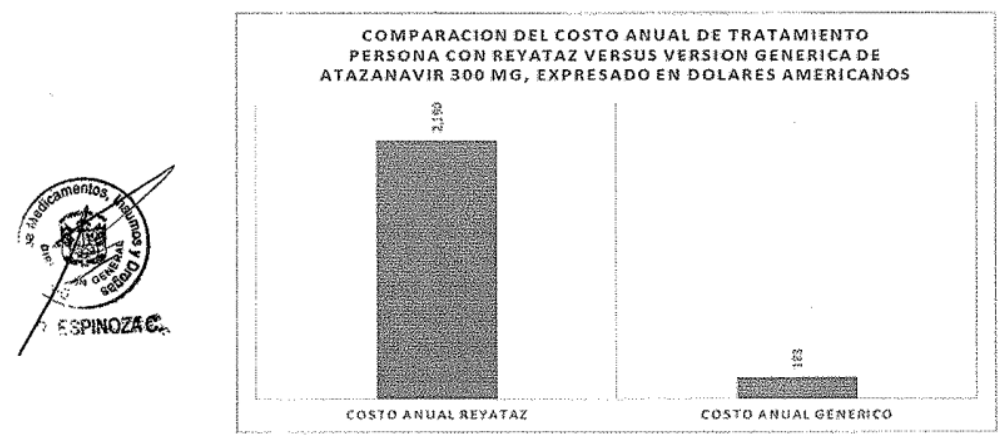

FUENTE: DIGEMID

Considerando la estimación del incremento de personas viviendo con el VIH que requerirán el uso de Atazanavir debido al cambio de los criterios de inicio de tratamiento del nuevo esquema que ha elaborado la Estrategia Sanitaria Nacional de Prevención y Control de Infecciones de Transmisión Sexual y VIH/SIDA y un escenario de reducción de brechas de tratamiento hacia el 2021; en la situación actual, el Estado tendría que gastar US\$15.330.000 en los próximos cuatro (03) años para financiar solo el tratamiento con Atazanavir $300 \mathrm{mg}$, en lugar de US\$1.277.500 que costaria con versiones genéricas. 
Estimación del costo total de tratamiento y ahorro por la adquisición de versiones genericas de Atazanavir, durante el periodo de portección de la patente de reyataz, expresado en millones de dolares americanos

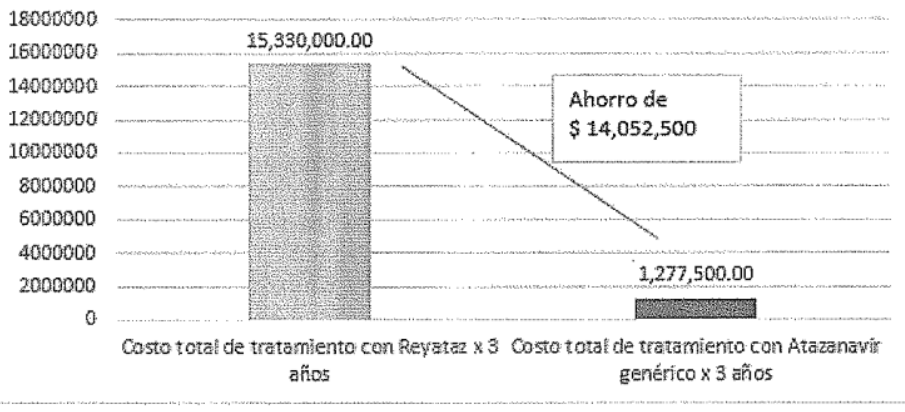

FUENTE: DIGEMID

Al respecto, las medidas que tome el Estado en uso de sus facultades o en ejecución de sus obligaciones señaladas en la normatividad, pueden y deben comprender el aspecto económico que viabiliza el cumplimiento de tales obligaciones en la práctica. Esto incluye el uso responsable, racional y legítimo de los recursos disponibles dentro del erario nacional.

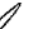

En ese sentido, resulta necesario declarar de interés público el acceso al medicamento Atazanavir, a fin de garantizar su disponibilidad y asequibilidad en todos los servicios de salud del sector público (Ministerio de Salud, Gobiernos Regionales, Essalud, Fuerzas Armadas y Fuerzas Policiales), y por ende la viabilidad y sostenibilidad del acceso universal y gratuito al tratamiento de los miles de pacientes que viven con ViH/SIDA, garantizándoles el derecho de recibir atención integral continua y permanente por parte del Estado Peruano.

La posibilidad de acceder al Atazanavir está directamente vinculado a su precio, tal como lo señala la OMS. No cabe separar una cosa de la otra. Una causa principal de la dificultad de acceder al producto Atazanavir es su alto costo. Queda claro que si el producto Atazanavir estuviese disponible libre de costo o a precios cercanos a cero, no habría un problema de acceso y no sería necesario recurrir a medidas previstas precisamente para resolver un problema de acceso.

El alto costo genera un gasto que puede ser utilizado por el mismo Ministerio de Salud en ampliar acciones como por ejemplo intervenciones preventivas promocionales e intervenciones para ampliar la cobertura del diagnóstico que permitan Incorporación de nuevas poblaciones identificadas con $\mathrm{VIH}$ que deben iniciar tratamientos y asegurar de por vida. (Carlos)

En el Perú se estima un total de 65000 personas con VIH/SIDA. De ellas, sólo el $51 \%$ sabe que tiene la enfermedad porque accedió a las pruebas de tamizaje. Esta es la brecha más importante en términos de salud pública para el control de la epidemia de VIH/SIDA en el Perú. Según ENDES 2008, sólo el $5.4 \%$ de los varones entre 15 a 49 años se realizó una prueba de $\mathrm{VIH}$ en los últimos doce meses. En el Plan estratégico multisectorial de VIH 2014 
2018 , se tiene como meta un incremento del tamizaje en un $25 \%$, lo cual podría mejorar si se contara con una adecuada disponibilidad presupuestal.

La presente norma no generará gastos adicionales al Estado, por el contrario nos permitirá reducir los gastos en el uso del medicamento Atazanavir y evitar dificultades en la provisión del mismo; siendo responsabilidad del Estado priorizar la recaudación y distribución presupuestal que permita cumplir con los objetivos trazados en política de salud.

CONSECUENCIAS ANTE UN DESABASTECIMIENTO

Si no se establecen mecanismos para asegurar la sostenibilidad financiera para comprar Atazanavir y otros antiretrovirales, las personas presentaran deterioro de su salud, complicaciones por el incremento en la multiplicación del virus en su organismo y la aparición de virus resistentes con mutaciones que evitan la acción de los medicamentos antiretrovirales. Consecuencia de esto, el paciente requerirá de nuevos medicamentos de mucho mayor costo y menor acceso.

\section{IMPACTO DE LA NORMA CON LA LEGISLACIÓN VIGENTE}

La declaración de interés público del acceso al medicamento Atazanavir, medicamento antirretroviral utilizado en el tratamiento para el VIH/SIDA, se enmarca y fundamenta en los principios y la normatividad nacional e internacional antes señalada, no implicando la derogación o modificación de norma alguna. 